Florida International University FIU Digital Commons

FIU Electronic Theses and Dissertations

University Graduate School

$7-2-2012$

\title{
The Distribution of Toxic and Essential Metals in the Florida Everglades
}

Zhiwei Duan

Florida International University, zduan001@fiu.edu

DOI: $10.25148 /$ etd.FI12080608

Follow this and additional works at: https://digitalcommons.fiu.edu/etd

\section{Recommended Citation}

Duan, Zhiwei, "The Distribution of Toxic and Essential Metals in the Florida Everglades" (2012). FIU Electronic Theses and Dissertations. 684.

https://digitalcommons.fiu.edu/etd/684

This work is brought to you for free and open access by the University Graduate School at FIU Digital Commons. It has been accepted for inclusion in FIU Electronic Theses and Dissertations by an authorized administrator of FIU Digital Commons. For more information, please contact dcc@fiu.edu. 


\title{
FLORIDA INTERNATIONAL UNIVERSITY
}

Miami, Florida

\section{THE DISTRIBUTION OF TOXIC AND ESSENTIAL METALS IN THE FLORIDA EVERGLADES}

\author{
A thesis submitted in partial fulfillment of \\ the requirements for the degree of \\ MASTER OF SCIENCE \\ in \\ CHEMISTRY \\ by
}

Zhiwei Duan

2012 
To: Dean Kenneth G. Furton

College of Arts and Sciences

This thesis, written by Zhiwei Duan, and entitled The Distribution of Toxic and Essential Metals in the Florida Everglades, having been approved in respect to style and intellectual content, is referred to you for judgment.

We have read this thesis and recommend that it be approved.

Yuan Liu

John Berry

Yong Cai, Major Professor

Date of Defense: July 2, 2012

The thesis of Zhiwei Duan is approved.

Dean Kenneth G. Furton

College of Arts and Sciences

Dean Lakshmi N. Reddi

University Graduate School

Florida International University, 2012 


\section{DEDICATION}

I dedicate this thesis to my family, especially to my wife Xiaoduo and to my parents for their love and unconditional support. 


\section{ACKNOWLEDGMENTS}

I would like to thank my major Professor Dr. Yong Cai, for his suggestions and guidance through my graduation studies.

I would like to thank my other committee members, Dr. John Berry and Dr. Yuan Liu, for their constructive comments and support.

I would like to thank Dr. Yanbin Li and Dr. Guangliang Liu for helpful comments and suggestions.

I would also like to thank Dr. Leonard Scinto for his helpful comments and support.

I would like to recognize my lab mates in the Department of Chemistry for their friendship and help throughout my research works: Dionne Dickson and Szabina Stice.

And many thanks to my family for their support and understanding. 


\section{ABSTRACT OF THE THESIS \\ THE DISTRIBUTION OF TOXIC AND ESSENTIAL METALS IN THE FLORIDA EVERGLADES \\ by}

Zhiwei Duan

Florida International University, 2012

Miami, Florida

Professor Yong Cai, Major Professor

Concentrations of 18 metals, including toxic metals ( $\mathrm{As}, \mathrm{Cd}, \mathrm{Cr}, \mathrm{Ni}$ and $\mathrm{Pb}$ ) and essential metals ( $\mathrm{Al}, \mathrm{Ba}, \mathrm{Be}, \mathrm{Co}, \mathrm{Cu}, \mathrm{Fe}, \mathrm{Li}, \mathrm{Mg}, \mathrm{Mn}, \mathrm{K}, \mathrm{Sr}, \mathrm{V}$ and $\mathrm{Zn}$ ) in various compartments (sediment, floc, and periphyton) were measured in the Florida Everglades to (i) establish the spatial distribution pattern of the metals in the Everglades and (ii) quantify the major sources of the 18 metals present in the Everglades. The highest mean concentrations of all metals analyzed in the Everglades were detected in soil, followed by floc and periphyton. Most metals exhibited random spatial distribution patterns. Risk assessment using Sediment Quality Guidelines (SQGs) concluded that all toxic metals (Cd, Cr, Pb, Ni, Cu, Zn and As) exhibited average concentrations that were well below FL guidelines as well as other domestic and international guidelines. On the basis of the current study, the Everglades can be considered a pristine environment. 


\section{TABLE OF CONTENTS}

CHAPTER

PAGE

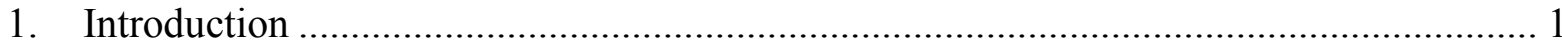

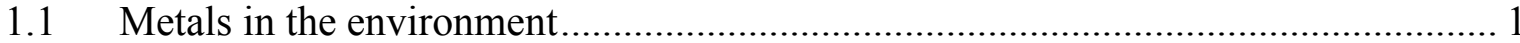

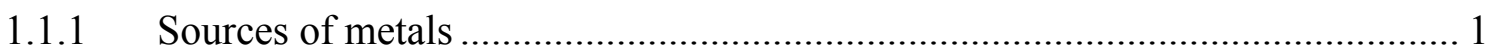

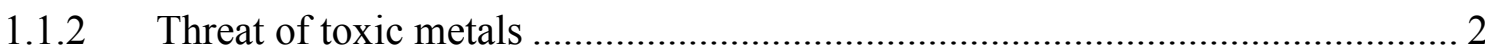

1.1.3 Importance of essential metals ........................................................................ 4

1.1.4 Cycling of metals in the aquatic system ………........................................ 5

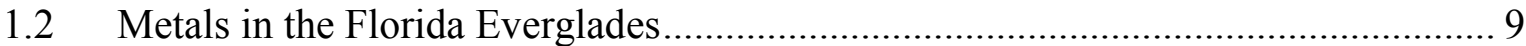

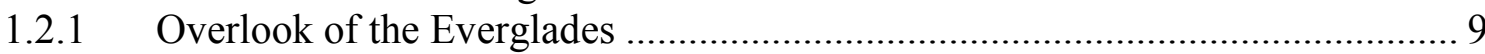

1.2.2 Possible sources of metals in the Everglades.............................................. 13

1.2.3 Previous studies on metals in the Everglades and surrounding areas ............... 14

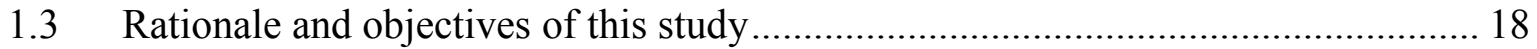

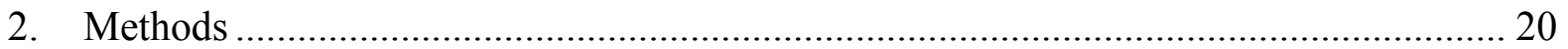

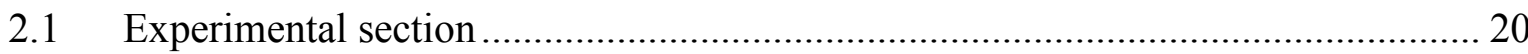

2.1.1 Sample collection.................................................................................. 20

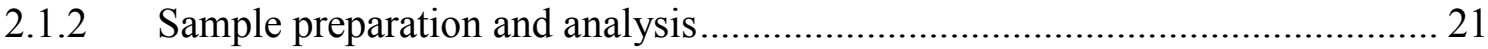

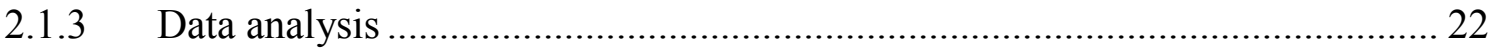

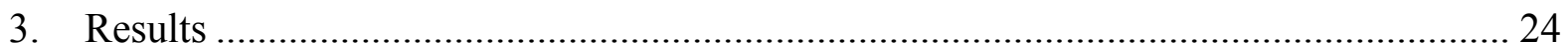

3.1 Metal concentrations in Florida Everglades soil, floc, and periphyton................... 24

3.2 Spatial distribution of metals in Everglades soil, floc and periphyton..................... 32

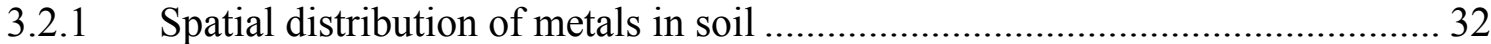

3.2.2 Spatial distribution of metals in the Florida Everglades floc........................... 37

3.2.3 Spatial distribution of metals in periphyton ................................................... 42

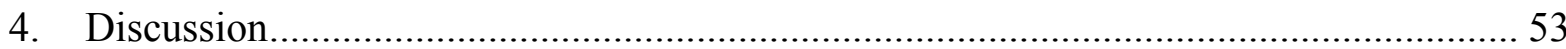

4.1 Factors influencing the spatial distribution of metals in the Florida Everglades ..... 53

4.1.1 Effects of possible sources on metal distribution in the Everglades................. 53

4.1.2 Effects of environmental parameters and metal-metal interactions on the

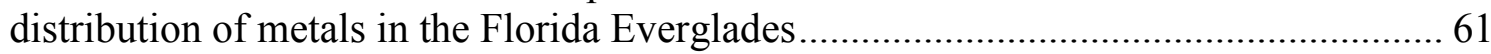

4.2 Risk assessment of toxic metals in the Florida Everglades...................................... 75

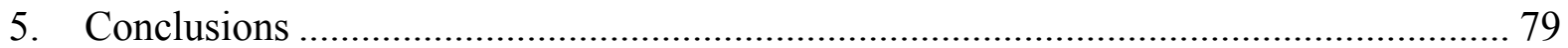

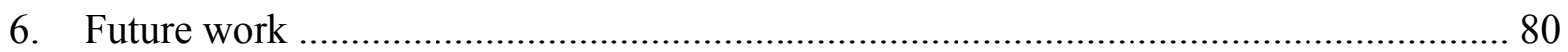

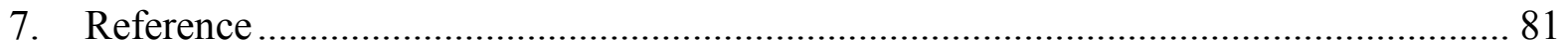




\section{LIST OF FIGURES}

FIGURE

PAGE

Figure 1-1 Diagram of As cycling in various matrices in an aquatic system ...................... 7

Figure 1-2 Satellite image of South Florida, including main components of the Florida Everglades: Everglades Agricultural Area (EAA); Arthur R. Marshall Loxahatchee National Wildlife Refuge (LNWR); Everglades Water Conservation Area 2 (WCA 2); Everglades Water Conservation Area 3; the eastern portion of Big Cypress National Preserve, and the freshwater portion of Everglades National Park (ENP). Light areas on the east are urban development (Scheidt and Kalla 2007).

Figure 2-1 A map showing sampling sites in the Florida Everglades. Sites were sampled during the dry (May) and wet season (November). LNWR: Arthur R. Marshall Loxahatchee National Wildlife Refuge; WCA-2 and WCA-3: Water Conservation Areas; ENP: Everglades National Park 21

Figure 3-1 Comparison of metal concentrations from soil in dry and wet season................. 27

Figure 3-2 Comparison of metal concentrations from floc in dry and wet season ............... 27

Figure 3-3 Comparison of metal concentrations from periphyton in dry and wet season ...... 27

Figure 3-4 Spatial variation of toxic metals in soils of the Florida Everglades (A) Cd, (B) Cr, (C) Ni, (D) As, and (E) Pb during the dry season (Top, labeled with capital letters) and wet season (bottom, labeled with lowercase letters).

Figure 3-5 Spatial variation of essential metals in soils of the Florida Everglades (A) Li, (B) $\mathrm{Be},(\mathrm{C}) \mathrm{V}$, (D) Mn, and (E) Co during the dry season (Top, labeled with capital letters) and wet season (bottom, labeled with lowercase letters).

Figure 3-6 Spatial variation of essential metals in soils of the Florida Everglades (A) Cu, (B) $\mathrm{Tl}$, (C) Zn, (D) Sr, and (E) Ba during the dry season (Top, labeled with capital letters) and wet season (bottom, labeled with lowercase letters).

Figure 3-7 Spatial variation of essential metals in soils of Florida Everglades (A) Al, (B) Fe, (C) $\mathrm{K}$ and (D) Mg during the dry season (Top, labeled with capital letters) and wet season (bottom, labeled with lowercase letters).

Figure 3-8 Spatial variation of toxic metals in floc of the Everglades (A) Cd, (B) Cr, (C) Ni, (D) As, and (E) Pb during the dry season (Top, labeled with capital letters) and wet season (bottom, labeled with lowercase letters). 
Figure 3-9 Spatial variation of essential metals in floc of Florida Everglades (A) Li, (B) Be, (C) V, (D) Mn, and (E) Co during the dry season (Top, labeled with capital letters) and wet season (bottom, labeled with lowercase letters).

Figure 3-10 Spatial variation of essential metals in floc of Florida Everglades (A) $\mathrm{Cu}$, (B) $\mathrm{Th}$, (C) $\mathrm{Zn}$, (D) Sr, and (E) Ba during the dry season (Top, labeled with capital letters) and wet season (bottom, labeled with lowercase letters). 40

Figure 3-11 Spatial variation of essential metals in floc of Florida Everglades (A) Al, (B) Fe, (C) $\mathrm{K}$, and (D) Mg during the dry season (Top, labeled with capital letters) and wet season (bottom, labeled with lowercase letters).

Figure 3-12 Spatial variation of toxic metals in Benthic Periphyton of Florida Everglades (A) $\mathrm{Cd}$, (B) $\mathrm{Cr}$, (C) $\mathrm{Ni}$, (D) As, and (E) $\mathrm{Pb}$ during the dry season (Top, labeled with capital letters) and wet season (bottom, labeled with lowercase letters).

Figure 3-13 Spatial variation of essential metals in benthic periphyton of Florida Everglades (A) $\mathrm{Li}$, (B) Be, (C) V, (D) Mn, (E) Co, (F) Cu (G) Tl during the dry season (Top, labeled with capital letters) and wet season (bottom, labeled with lowercase letters).

Figure 3-14 Spatial variation of essential metals in benthic periphyton of Florida Everglades (A) $\mathrm{Zn}$, (B) Sr, (C) Ba, (D) Al, (E) Fe, (F) K, (G) Mg during the dry season (Top, labeled with capital letters) and wet season (bottom, labeled with lowercase letters).

Figure 3-15 Spatial variation of toxic metals in Epiphytic periphyton of Florida Everglades (A) $\mathrm{Cd}$, (B) Cr, (C) Ni, (D) As, and (E) Pb during the dry season (Top, labeled with capital letters) and wet season (bottom, labeled with lowercase letters).

Figure 3-16 Spatial variation of essential metals in epiphytic periphyton of Florida Everglades (A) Li, (B) Be, (C) V, (D) Mn, (E) Co, (F) Cu (G) Tl during the dry season (Top, labeled with capital letters) and wet season (bottom, labeled with lowercase letters). 47

Figure 3-17 Spatial variation of essential metals in epiphytic periphyton of Florida Everglades (A) Zn, (B) Sr, (C) Ba, (D) Al, (E) Fe, (F) K, (G) Mg during the dry season (Top, labeled with capital letters) and wet season (bottom, labeled with lowercase letters). .......... 48

Figure 3-18 Spatial variation of toxic metals in floating periphyton of Florida Everglades (A) $\mathrm{Cd}$, (B) $\mathrm{Cr}$, (C) $\mathrm{Ni}$, (D) As, and (E) $\mathrm{Pb}$ during the dry season (Top, labeled with capital letters) and wet season (bottom, labeled with lowercase letters).

Figure 3-19 Spatial variation of essential metals in floating periphyton of Florida Everglades (A) Li, (B) Be, (C) V, (D) Mn, (E) Co, (F) Cu (G) Tl during the dry season (Top, labeled with capital letters) and wet season (bottom, labeled with lowercase letters). 50 
Figure 3-20 Spatial variation of essential metals in floating periphyton of Florida Everglades (A) Zn, (B) Sr, (C) Ba, (D) Al, (E) Fe, (F) K, (G) Mg during the dry season (Top, labeled with capital letters) and wet season (bottom, labeled with lowercase letters)

Figure 4-1 Metals with elevated concentrations $(\mathrm{mg} / \mathrm{Kg}$ ) for $\mathrm{Cu}, \mathrm{As}, \mathrm{Pb}$ and $\mathrm{Zn}$ in soils from the dry season that are possibly affected by fertilizers applied in EAA ............................. 56

Figure 4-2 Distribution of metals ( $\mathrm{Cr}$, As and $\mathrm{Zn})$ in soil $(\mathrm{mg} / \mathrm{kg})$ from the dry season possibly influenced by road traffic, airboat trails and airport ......................................... 58 Figure 4-3 Diagram showing canals and levees in the Everglades (Light and Dineer 1994). 60 Figure 4-4 Distributions of $\mathrm{Cu}, \mathrm{As}, \mathrm{Pb}$ and $\mathrm{Zn}(\mathrm{mg} / \mathrm{Kg})$ as well as ash free weight (\%) from

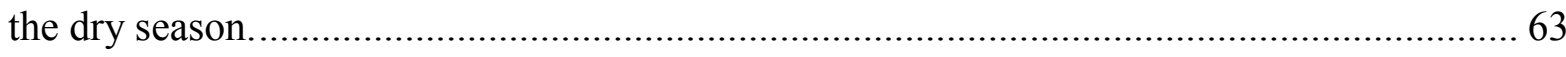

Figure 4-5 Distributions of $\mathrm{Ni}, \mathrm{Mn}, \mathrm{Li}$ and $\mathrm{Be}(\mathrm{mg} / \mathrm{Kg})$ as well $\mathrm{pH}$ from the dry season..... 65

Figure 4-6 Distributions of $\mathrm{Mn}, \mathrm{Zn}$ and $\mathrm{Co}(\mathrm{mg} / \mathrm{Kg})$ in epiphytic periphyton from the dry season

Figure 4-7 Distributions of $\mathrm{Cu}, \mathrm{As}, \mathrm{Pb}$ and $\mathrm{Zn}(\mathrm{mg} / \mathrm{Kg})$ in benthic periphyton from the dry season

Figure 4-8 Spatial distribution of selected toxic metals with concentrations exceeding SQGs in soils (A) As, (B) Cr, (C) Pb, and in floc of Florida Everglades (D) As, and (E) Ni, (F) Cu 


\section{LIST OF TABLES}

TABLE

PAGE

Table 2-1 Detection Limits of trace metals by ICP-MS

23

Table 3-1 Average concentrations of metals in all matrices (soil, floc, and periphyton) in dry season $(\mathrm{mg} / \mathrm{kg}$ for all metals except for $\mathrm{Al}, \mathrm{Fe}$ and $\mathrm{Mg}$ given in $(\mathrm{mg} / \mathrm{g}))$ 25

Table 3-2 Average concentrations of metals in all matrices (soil, floc, and periphyton) in wet season $(\mathrm{mg} / \mathrm{kg}$ for all metals except for $\mathrm{Al}, \mathrm{Fe}$ and $\mathrm{Mg}$ given in $(\mathrm{mg} / \mathrm{g}))$.......................... 26

Table 3-3 correlation matrix of metals (soils, $\mathrm{x}$ axis) versus periphyton ( $\mathrm{y}$ axis) ................ 29

Table 3-4 Correlation matrix of metals (soils, $\mathrm{x}$ axis) versus floc (y axis)......................... 30

Table 3-5 correlation matrix of metals (floc, $\mathrm{x}$ axis) versus periphyton (y axis)................. 31

Table 4-1 Comparison of toxic metals in P fertilizers and in sediment quality guidelines (SQGs) LEL=Lowest Effect Levels; TEL= threshold effect levels; SEL=severe effect level; $\mathrm{PEL}=$ probable effect levels................................................................................ 55

Table 4-2 Hard and soft acids (metal ions) and bases (ligands) (EPA 2007)...................... 64

Table 4-3 Correlations between metals in matrices (soil and floc) and environmental parameters (DOM, pH, ash free weight (AFW) and Eh) ............................................. 67

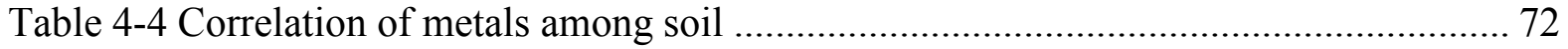

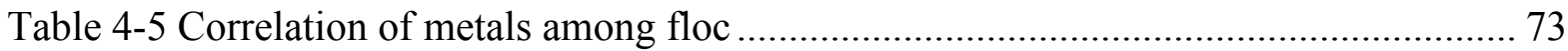

Table 4-6 Correlation of metals among periphyton .......................................................... 73

Table 4-7 Summary of sediment quality guidelines (SQGs) summary SQG derivation: BK = background based; $\mathrm{ED}=$ empirically derived; $\mathrm{CB}=$ Consensus based. (Apitz et al. 2007) .. 77

Table 4-8 Percentages of toxic metals over the SQG's limit from sediment and floc samples 
1. Introduction

1.1 Metals in the environment

\subsubsection{Sources of metals}

Metals are an integral part of the earth and they can originate from both natural and anthropogenic sources (Nagajyoti et al. 2010). Some metals mainly originate from natural source, e.g., aluminum (Al), iron $(\mathrm{Fe})$, calcium $(\mathrm{Ca})$ and potassium $(\mathrm{K})$. Geothermal sources, such as volcanic eruptions, are one of the major natural sources of metal (Nagajyoti et al. 2010). Volcanic eruptions have been known to release high levels of toxic metals into the environment by wind force (Nagajyoti et al. 2010). Other natural sources include marine aerosols, forest fires, and sea sprays (Florea and Busselberg 2006). Some metals, such as cadmium $(\mathrm{Cd})$, arsenic (As), and chromium $(\mathrm{Cr})$, are mostly attributed to anthropogenic sources although those metals can also be found in nature at trace levels (Nagajyoti et al. 2010). There are several types of major anthropogenic sources for metals, which include industry, agriculture, atmosphere, and others (Nagajyoti et al. 2010). Many potentially toxic metals, including $\mathrm{Cd}, \mathrm{Cr}$, lead $(\mathrm{Pb})$, nickel $(\mathrm{Ni})$, and zinc $(\mathrm{Zn})$ can be generated from industrial activities. Lead was used in gasoline as an antiknock agent for almost a century before leaded gasoline was phased-out (Florea and Busselberg 2006). It is also used in the paint, radiation shields, car batteries, glass and soldering. Nickel is widely used in the metalprocessing industry such as stainless steel makings, coinage and alloys (Florea and Busselberg 2006). Burning of fossil fuels have contributed to the elevated levels of Ni in the city soils (Raposo et al. 2001). Cadmium has been used in the manufacturing of batteries, plating, pigments and plastics. Agricultural sources of toxic metals result from use of inorganic fertilizers $(\mathrm{Cd}, \mathrm{Cr}, \mathrm{Ni}, \mathrm{Pb}$ and $\mathrm{Zn}$ ), animal manure (Manganese $(\mathrm{Mn}), \mathrm{Zn}$, copper 
$(\mathrm{Cu})$ and cobalt $(\mathrm{Co})$ ) and sewage sludge $(\mathrm{Zn}, \mathrm{Cr}, \mathrm{Pb}, \mathrm{Ni}, \mathrm{Cd}$ and $\mathrm{Cu}$ ) (Verkleji 1993; Nagajyoti et al. 2010). Toxic metals can be distributed as results of atmospheric sources, such as rain and snowfall. Other possible sources include coal burning plants $(\mathrm{Cd}$, mercury ( $\mathrm{Hg}$ ), $\mathrm{Mn}, \mathrm{Ni}, \mathrm{Al}, \mathrm{Fe}$ and titanium (Ti)), vehicle emissions (Cd, $\mathrm{Cr}, \mathrm{Hg}, \mathrm{Ni}, \mathrm{Pb}$ and $\mathrm{Zn}$ ) and landfill pollutions (Zn, Pb, Al, tin ( $\mathrm{Sn}$ ), Fe and $\mathrm{Cu}$ ) (Verkleji 1993; Nagajyoti et al. 2010). Agricultural run-offs and wastes from industry are also responsible for the contamination of metals in the aquatic ecosystems (Sharma and Sohn 2009).

\subsubsection{Threat of toxic metals}

Metal pollution has emerged as a worldwide problem that results from increased anthropogenic activities as well as natural processes (Florea and Busselberg 2006). Of all metals, Cadmium, $\mathrm{Hg}, \mathrm{Pb}, \mathrm{Cr}, \mathrm{As}, \mathrm{Cu}, \mathrm{Ni}$, and $\mathrm{Zn}$ are of greatest concern because of their high toxicities and threats to human and wildlife (Florea and Busselberg 2006). Toxic metals are detrimental not only to terrestrial animals and plants but also to fish, birds, and other organisms in aquatic environments. Heavy metal pollution from domestic water and sewage alone can cause long-lasting harm to both aquatic plants and animals (Nriagu 1988).

Toxic metals can affect plants via a variety of pathways. Zinc can cause chlorosis in young leaves and thus constrain the growth above and below ground (Lee et al. 1996). Chromium can significantly depress the capability of plants to carry out photosynthesis (Clijsters and Vanassche 1985). Lead is known as a non-essential metal for the growth of plants, and is considered detrimental to plants cells if accumulated (Kaznina et al. 2005). High level of $\mathrm{Pb}$ was found in algae in both short and long term exposure (Scheidegger et al. 2011). Long term exposure to $\mathrm{Pb}$ could cause damage to metabolism, decrease in the photosynthetic activity, and elevation in the production of reactive oxygen species which 
lead to the slow growth and development of plants (Kaznina et al. 2005). In addition, the excess of $\mathrm{Pb}$ may also inhibit enzyme activities and alter mineral nutrition (Sharma and Sohn 2009). Cadmium is another well-studied toxic metal (Tolley et al. 1992; Su et al. 2009). Cadmium along with $\mathrm{Pb}$ can cause lipid peroxidation, metabolite degradation, overproduction of $\mathrm{H}_{2} \mathrm{O}_{2}$, declination in the protein amount and DNA damage, and ultimately cell death (Piotrowska et al. 2010). Arsenite (As ${ }^{\mathrm{III}}$ ) is the most toxic inorganic As forms (Mass et al. 2001). Trivalent arsenic has high affinity for biomolecules such as glutathione (GSH) and cysteinyl residues of enzymes, and can affect the activity of a number of enzymes (Aposhian and Aposhian 2006). Toxic metals at high concentration not only threaten plants, but also pose serious dangers to animals. Arsenic is one of the most well-known environmental pollutants because of its prevalent existence, high toxicity and bioaccumulation potential. It widely exists in water and soil and poses great threats to humans. Acute effects of As poisoning range from irritation to the nose and throat to nausea, vomiting and diarrhea (Florea and Busselberg 2006). Chronic exposure of As leads to cancer, liver damage and dermatosis (Florea and Busselberg 2006). Arsenic is also known to be toxic to many aquatic organisms from daphnids (water fleas) to fish (zebrafish and rainbow trout) (Elnabarawy et al. 1986). Lead can induce damage to and the part of nervous systems (Florea and Busselberg 2006). Prolonged exposure to $\mathrm{Pb}$ could affect encoding as well as storage and retrieval of verbal information (Marchetti 2003). Excess $\mathrm{Pb}$ in the human body can lead to harmful effects on calcium dependent proteins and neurotransmitters receptors (Florea and Busselberg 2006). Lead also can act as a strong neurotoxin that causes brain damage and cognitive deficits in children (Huang and Schneider 2004). The target organs of chromium (VI) toxicity include skin, mucous and respiratory tract (Salem et al. 1994). Cancer induced 
by Cr has also been reported (Rossi and Wetterhahn 1989). Chronic inhalation exposure to Ni can cause respiratory problem and even death (Rendell et al. 1994). Cadmium can have adverse effects on calcium metabolism, food intake, and hardness of eggshells (Burger 2008). Acute $\mathrm{Cd}$ poisoning can cause severe irritation to the stomach, leading to diarrhea and even death.

\subsubsection{Importance of essential metals}

Essential metals provide some critical biochemical components to enzymatic reaction for organisms (Goyer 1997). Animals will not survive in the absence of essential metals, which support functions of vital organs. Nine metals $(\mathrm{Co}, \mathrm{Cr}, \mathrm{Cu}, \mathrm{Fe}, \mathrm{Mg}, \mathrm{Mn}$, molybdenum (Mo), selenium (Se) and $\mathrm{Zn}$ ) are considered nutritionally essential to human (Florea and Busselberg 2006). Trace elements including $\mathrm{Al}$, boron (B), $\mathrm{Co}, \mathrm{Cu}, \mathrm{Fe}, \mathrm{Mn}, \mathrm{Mo}, \mathrm{Ni}$, rubidium $(\mathrm{Rb}), \mathrm{Ti}$, vanadium $(\mathrm{V})$ and $\mathrm{Zn}$ are considered essential to plants (Kabata-Pendias 2004). Although some of these essential metals can also be detrimental at high concentrations.

Essential metals are necessary for a variety of processes in animals and plants. Some essential metals (e.g., $\mathrm{Zn}, \mathrm{Fe}$ and $\mathrm{Ca}$ ) are involved in key metabolic processes such as respiration, photosynthesis, fixation and assimilation of some major nutrients such as nitrogen and sulfur. Others are known to be important for maintaining the activity of enzymes (e.g., $\mathrm{Cu}, \mathrm{Fe}, \mathrm{Mn}$, and $\mathrm{Zn}$ ). Some metals (e.g., $\mathrm{Al}, \mathrm{Cu}, \mathrm{Co}, \mathrm{Mo}, \mathrm{Mn}$, and $\mathrm{Zn}$ ) are known to be responsible for protection mechanisms of frost-hardy and drought-resistant plant (Kabata-Pendias 2004). In the aquatic ecosystem, $\mathrm{Cu}$ and $\mathrm{Zn}$ are essential micronutrients for maintaining normal functions of many enzyme systems in both algae and higher plants. Manganese oxidation is important for the growth of algae (Knauer et al. 1999). 
Manganese also plays an important role in the photosynthesis of algae (Jahnke and Soulen 1978).

\subsubsection{Cycling of metals in the aquatic system}

Elevated metals have been increasingly observed in wildlife of many aquatic ecosystems as results of the increase in human activities, posing severe threat to both human and environmental health. Metals can enter aquatic ecosystems through various sources (e.g., atmosphere deposition, runoffs, and river). Once in the aquatic ecosystem, metals will go through a number of biogeochemical processes and be distributed into various compartments of aquatic systems (Warren and Haack 2001). These processes mainly include adsorption/desorption, transformation between different metal species, exchange of metals in the sediment-water interface (diffusion and suspension/precipitation), uptake of metals by microorganisms or plants, and bioaccumulation along food chain (Christensen et al. 2001; Warren and Haack 2001; Weng et al. 2002). The biogeochemical cycling of As is shown in Figure 1-1. In the aquatic system, adsorption/desorption is an important biogeochemical process as it is one of the controlling factors of concentrations of toxic metals in the aquatic environment (Sullivan and Aller 1996). Arsenic, $\mathrm{Pb}$ and $\mathrm{Cd}$ are commonly involved in the adsorption/desorption process with metal oxides (e.g., Fe and Mn) in soil. The process is strongly affected by $\mathrm{pH}$ and concentrations of adsorbents (Davis and Leckie 1978). Furthermore, sediment-water interface reactions are responsible for metal partitioning between the solid and solution phases (Warren and Haack 2001). Metal partitioning is affected by many factors, such as the system $\mathrm{pH}$, ionic strength, and content of dissolved organic matter (DOM) as well as the characteristics and concentrations of solid sorbents and the kinetics of relevant reactions (Warren and Haack 2001). After partitioning process of 
metals in different phases, metals are initially taken up by either cyanobacteria or plants in the aquatic system. During the cycling processes, some metals are transformed under the influence of microorganisms, either by redox processes (e.g., Fe and Mn) or by akylation (e.g., Hg) (Ledin 2000). Bacteria can methylate arsenic to form both volatile (e.g., methylarsines) and nonvolatile (e.g., monomethylarsonic acid (MMAA) and dimethylarsinic acid (DMAA) compounds (Duester et al. 2005). Marine algae can also transform arsenate into MMAA and DMAA in seawater. Over time, accumulation of metals occur in two ways: sorption (passive) or intracellular, metabolism-dependent (active) uptake. Passive accumulation is affected by metal binding functional groups on the cell surface, as well as metal speciation in the aquatic phase. Active uptake of metals relies on an energy source (Ledin 2000). Fish and plants contaminated with heavy metals are consumed by larger organisms via digestions. The potentially toxic metals are then returned to the aquatic environment through excretion. 


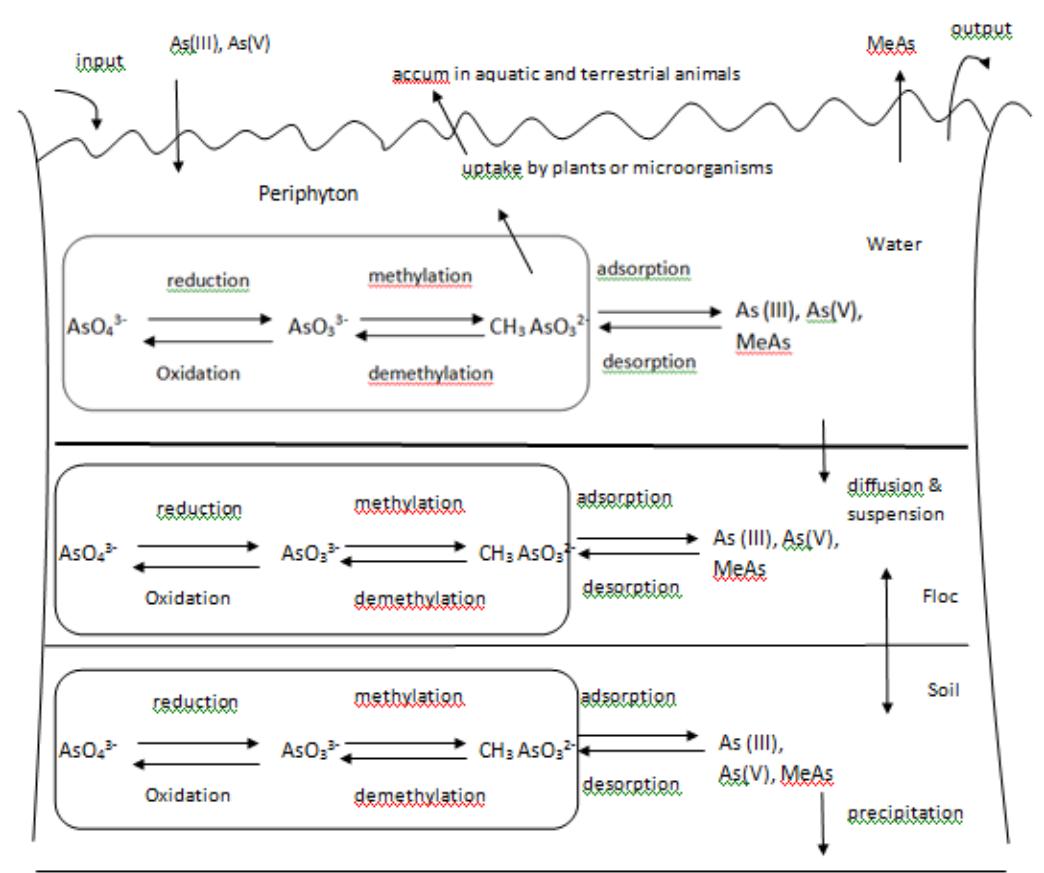

Figure 1-1 Diagram of As cycling in various matrices in an aquatic system

Cycling and fate of metals in aquatic systems are determined by many environmental factors, including $\mathrm{DOM}, \mathrm{pH}$, redox potentials, and metal-metal interactions. A heterogeneous complex of different molecular weight species with variety of water solubilities and reactivities makes up DOM (Aiken et al. 2011). DOM can form soluble complexes with toxic metals, increasing their solubility and altering their biogeochemical cycles (Hesterberg 1998). Because of high natural production of organic carbon in many aquatic ecosystems, Dissolved Organic Matter could have a strong influence on the behavior of metals (Aiken et al. 2011). Soil/sediment $\mathrm{pH}$ has a substantial impact on the solubilities of metals. For example, metal cations $(\mathrm{Cu}, \mathrm{Pb}, \mathrm{Zn}, \mathrm{Ni}$ and $\mathrm{Al})$ become more adsorbed under more basic condition (Adriano 1986), whereas metal anions tend to be less adsorbed under the same condition. In addition, redox potential affects the metal cycles in the aquatic environment by changing phases of metal species (solid Mn (IV) mineral, Fe (III) 
mineral reduced to aqueous $\mathrm{Mn}^{2+}$ and $\mathrm{Fe}^{2+}$ ) (Hesterberg 1998). As a result, toxic metals (As, $\mathrm{Cd}$ and $\mathrm{Pb}$ ) associated with $\mathrm{Mn}$ - and $\mathrm{Fe}$ - oxides minerals can change their solubilities. Metal-metal interactions may influence cycling of metals via several pathways, 1) formation of colloids which can influence the adsorption/desorption and bioavailability of metals, 2) formation of metal-metal complexes that enhance or inhibit the uptake of metal, and 3) competing for the binding sites on proteins or solids which can affect the adsorption/desorption or toxicity of metals. The metal-colloid complexes can be formed between toxic metals and metals that are considered micronutrients, such as $\mathrm{Zn}, \mathrm{Fe}$, and $\mathrm{Ca}$ (Peraza et al. 1998). Rahman and co-workers (2008) found a positive correlation between As and Fe concentrations in the same aquatic plant exposed to As solution suggesting the adsorption of As on ferric iron inhibited the mobility of As into the roots of duckweed. David Wright (1995) determined that an inversely correlation exists between $\mathrm{Ca}$ and $\mathrm{Cd}$ concentrations through experiments on perch eggs. Toxic metals can compete with essential metals for binding sites. Cadmium can potentially interfere with metabolism of four metals essential to nutrition $(\mathrm{Fe}, \mathrm{Zn}, \mathrm{Ca}$ and $\mathrm{Cu}$ ). Furthermore, increased concentration of $\mathrm{Cd}$ decreases $\mathrm{Fe}$ and $\mathrm{Cu}$ absorption. Lead competes, with $\mathrm{Ca}$ for binding sites on intestinal mucosal proteins, with iron for transport systems of the intestine, and with $\mathrm{Zn}$ for GastroIntestinal uptake, respectively. Arsenic is known to interact with Se and Zn. Antagonistic effects are also discovered between As and Se. Arsenic also binds with Zn although the mechanism is unknown (Peraza et al. 1998). It was postulated that trace metals inhibit gill Ca ATPase in the order $\mathrm{Hg}^{2+}>\mathrm{Pb}^{2+}>\mathrm{Cu}^{2+}>\mathrm{Cd}^{2+}>\mathrm{Zn}^{2+}$ (Viarengo and Nott 1993). In aquatic plants, $\mathrm{Zn}$ has been shown to reduce $\mathrm{Cu}$ toxicity by promoting antioxidant defense as well 
as increasing chlorophyll and carotenoid contents in the freshly grown aquatic plant, duckweed (Upadhyay and Panda 2010).

\subsection{Metals in the Florida Everglades}

\subsubsection{Overlook of the Everglades}

The Florida Everglades is a unique subtropical wetland environment (Fig 1-2), which varies seasonally in term of ecological conditions. Majorie Stoneman Douglas (1947) praises the uniqueness of the Everglades in her famous book "River of Grass". It is large (originally $\left.\sim 1.6 \times 10^{6} \mathrm{ha}\right)$, near sea level $(3 \pm 3 \mathrm{~m}$ elevation $)$, wet in summer and dry in most of winters (Merkel and Hickey-Vargas 2000). Water used to flow freely through the Kissimmee chain of lakes in central Florida into the Kissimmee River and south into Lake Okeechobee (Clarke and Dalrymple 2003). Lake Okeechobee would overflow during the subtropical rainy season and send water to Florida Bay. As a result of the flat landscape, water used to proceed as a 30-mile wide sheet of flowing water (Clarke and Dalrymple 2003). South Florida is known for its diverse plants species as well as some endangered animal species (Scheidt and Kalla 2007). Cypress swamps, pine and mangrove forests are among major plants around the Everglades area (MePherson and Halley 1996). The suitable landscapes have supported animals including snail kite, wood stork, Florida black bear and Florida alligator. Among animal species living in the Everglades area, the Florida panther, alligators and manatees are

on the endangered species list. Flooding has become a major issue for the early human settlers with agricultural interests. In order to minimize the damage flooding would cause on the crops, more than 400 miles of canals, levees and dams were constructed to drain the wetland in the south Florida by the early 1900s (Sklar et al. 1999). Even longer canals and levees, along with water control structures and pump stations, were installed in an effort to 
further drain the area. Fresh water (1.7 billion gallons/day on average) was to be routed directly to the sea to avoid flooding upon storm events. The excessive drainage dramatically altered the fragile balance of fresh to salt water in the south Florida area (Clarke and Dalrymple 2003). As a result of regulating overland flow of water, natural resources within the Everglades area (LNWR, WCA-2, WCA-3, ENP) were significantly degraded (SFWMD 1999). Drained peat soils were oxidized because of the lowered water table (EAA), resulting in the sink of the land surface by 3-10 feet (Perry 2008). The increased nutrient level in the Everglades soil, from nearby agricultural and urban development, has shifted vegetation community dynamics (Davis 1991; Merkel and Hickey-Vargas 2000). Other adverse impacts include enhancement of organic matter decomposition and microbial activity leading to the increase of nutrient concentrations in floodwater (Wright and Reddy 2001).

Today, the great Florida Everglades are dramatically different in terms of ecology and hydrology. The excessive drainage caused by water management results in increased highly productive algal-phytoplankton blooms, declines in sea grass beds and coral communities (MePherson and Halley 1996). Population of wading birds have been mitigated by a staggering $85-90 \%$ for those that nest their young in the Everglades (Clarke and Dalrymple 2003). The change in the water distribution has alternated habitat for both plants and animals in addition to the salinity changes (Horrocks and Ogden 1994). The hydrological alternation is blamed for the dramatic declines of fish and wildlife populations.

In an effort to restore conditions in the Everglades back to the pre-development state where landscape can support abundant wildlife and plants, the Comprehensive Everglades Restoration plan (CERP) was created. In 2000, the legislation regulating CERP was signed into law By President Clinton with an estimated funding of $\$ 7.8$ billion for a 30 -year project. 
The goal of the plan was to restore the ecological beauty in the Everglades area. However, the consideration for contribution by human activities to the pollution in the Everglades area has been largely neglected by CERP. A report prepared by the U.S. General Accounting office has called for the need to fill data gaps in the scientific information on potentially harmful contaminants and their risks to native aquatic organisms. 

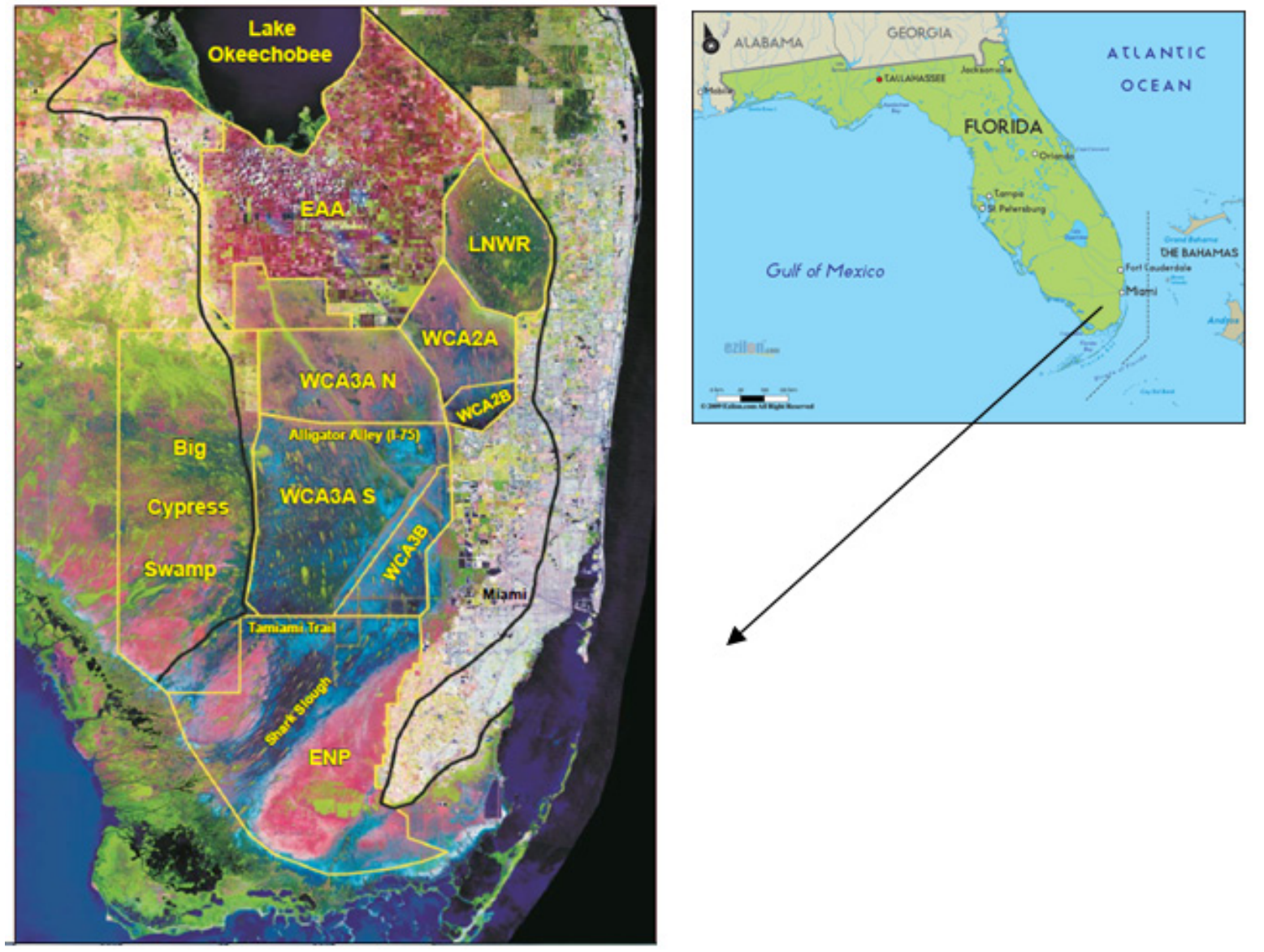

Figure 1-2 Satellite image of South Florida, including main components of the Florida Everglades: Everglades Agricultural Area (EAA); Arthur R. Marshall Loxahatchee National Wildlife Refuge (LNWR); Everglades Water Conservation Area 2 (WCA 2); Everglades Water Conservation Area 3; the eastern portion of Big Cypress National Preserve, and the freshwater portion of Everglades National Park (ENP). Light areas on the east are urban development (Scheidt and Kalla 2007). 


\subsubsection{Possible sources of metals in the Everglades}

Metal distributions in the Everglades are under influences from several sources, including agriculture, atmospheric deposition, road traffic, landfill, wastewater management, tourism (airboat), airport, cattle ranching and dairy farming (Chaney and Ryan 1993; Chen et al. 1997; Viard et al. 2004; Carriger et al. 2006; Dragovic et al. 2008). With the flow of drainage water from Everglades Agriculture Area (EAA) into the Water Conservation Areas (WCAs), metals contained in pesticides and fertilizers (e.g., $\mathrm{Mg}, \mathrm{K}, \mathrm{Al}, \mathrm{Fe}, \mathrm{Cr}, \mathrm{Cd}, \mathrm{As}, \mathrm{Hg}$ and $\mathrm{Pb}$ ) can become inputs in the Everglades (Craft and Richardson 1997). Atmospheric inputs such as wind and rainfall can contribute to the metal distributions as well (Pironfrenet et al. 1994; Lu et al. 2003). Florida is one of the regional background locations with the highest rates of $\mathrm{Hg}$ deposition (Sillman et al. 2007). Atmospheric deposition of $\mathrm{Cd}$ and $\mathrm{Pb}$ from rains and aerosols originated in fertilizers (Pironfrenet et al. 1994; Dammgen et al. 2000) is another possible alternate source affecting metal distributions in the Everglades. Motor vehicle emissions on surrounding roads may also contribute to some metals (e.g., $\mathrm{Zn}, \mathrm{Pb}, \mathrm{Cd}$ ) (Garcia et al. 1996; Othman et al. 1997; Viard et al. 2004; Calace et al. 2012). Waste water, including discharge from domestic and industrial treatment plant as well as runoff from landfill, can also contribute to aggravated levels of metals in the Everglades area (McPherson 1990). The Florida Everglades is a well- known tourist spot with airboat guided tour being one of the most popular activities. Kendall-Tamiami Airport (KTMB), one of the "busiest general aviation airports in Florida", is located not too far from the southeastern region of Everglades National Park. They might contribute to $\mathrm{Pb}$ in the Everglades because $\mathrm{Pb}$ is an ingredient used in the jet fuel (EPA 2010). Cattle ranching and dairy farming are another prominent agriculture activity that affects the ecosystem. High densities of cattle can be seen 
in the surrounding areas of Everglades in Hendry, Palm Beach, Broward, Miami-Dade and Collier counties (MePherson and Halley 1996). Sewage biosolids that are applied to dairy farm lands surrounding the Everglades could contribute to the elevated levels of toxic metals $(\mathrm{Cd}, \mathrm{Cr}, \mathrm{Ni}, \mathrm{Pb})$ in underground water and runoffs (Richards et al. 2004).

\subsubsection{Previous studies on metals in the Everglades and surrounding areas}

Several previous studies have investigated levels of several metals in Biscayne Bay, the Florida Keys, Florida Bay, and surrounding estuaries (Windom et al. 1989; Strom et al. 1992). Lead and Zn contamination were found in Biscayne Bay and Pensacola Bay as determined from comparisons between sample data with metal-aluminum relationships designed for natural uncontaminated sediments collected from the same region (Windom et al. 1989). Carnahan and co-workers (2008) reported distributions of 11 heavy metals (Cu, $\mathrm{Zn}$, $\mathrm{Cr}, \mathrm{Hg}, \mathrm{Pb}, \mathrm{Ni}, \mathrm{Ag}, \mathrm{As}, \mathrm{Cd}, \mathrm{Sb}$ and $\mathrm{Sn}$ ) in Biscayne Bay sediments in Florida. Silver, As, $\mathrm{Sb}$, $\mathrm{Sn}$, and $\mathrm{Cd}$ were rarely detected whereas $\mathrm{Cu}, \mathrm{Hg}, \mathrm{Ni}, \mathrm{Pb}$, and $\mathrm{Zn}$ were frequently detected using inductively coupled plasma-optical-emission spectrometry (ICP-OES) and a flowinjection mercury system (FIMS). Elevated levels of $\mathrm{Pb}$ were found in most samples, compared with establish criteria. The highest concentrations of $\mathrm{Cu}, \mathrm{Zn}, \mathrm{Cr}, \mathrm{Hg}, \mathrm{Pb}$, and $\mathrm{Ni}$ were found closest to Miami and near the mouths of several canals along the western margin of the bay. Strom et al. (1992) investigated trace metal concentrations (As, $\mathrm{Pb}, \mathrm{Cu}$, and $\mathrm{Cd}$ ) in the sediments and producer as well as consumer organisms in samples from Florida Keys. Concentrations of As (<0.2 ppm), $\mathrm{Pb}(0.8-4.5 \mathrm{ppm}), \mathrm{Cd}(0.2-1.2 \mathrm{ppm}), \mathrm{Cu}(0.8-3.8 \mathrm{ppm})$ were measured. The results showed that the Florida Keys had low metal pollutions with a few anthropogenic effects (human inputs). A few studies have been done on the distribution 
of metals and their implications in the surrounding areas of the Everglades (Caccia and Millero 2003; Carnahan et al. 2008; Rand and Schuler 2009). Caccia et al. (2003) studied distribution of trace metals ( $\mathrm{Sc}, \mathrm{V}, \mathrm{Ba}, \mathrm{Cd}, \mathrm{Cr}, \mathrm{Co}, \mathrm{Cu}, \mathrm{Pb}, \mathrm{Mn}, \mathrm{Ni}, \mathrm{Zn}, \mathrm{Al}, \mathrm{Mg}$, and $\mathrm{Fe}$ ) in Florida Bay sediments and concluded all metals exhibited similar distribution pattern with except for $\mathrm{Mn}$ and Fe. The highest concentrations were influenced by the input and runoff from the Taylor Slough. Maximum concentrations of those metals in the Florida Bay were found to be lower than those in most estuarine systems in the United States. The organic material in the Florida Bay originated from detritus of sea grasses as determined using the ratio of the percentage of organic carbon and nitrogen in the sediments (Caccia and Millero 2003). The strong correlations were found between $\mathrm{Al}$ and metals ( $\mathrm{Ni}, \mathrm{Cr}, \mathrm{Pb}, \mathrm{Ba}, \mathrm{Fe}, \mathrm{V}, \mathrm{Cu}$ and $\mathrm{Zn}$ ) suggesting close association of those metals with fine fraction of the sediments (aluminosilicates).

Few studies conducted in the Everglades focused on source and fate of metals. Very little interest was given with regard to possible pollution associated with metals in the past century (Kushlan and Hunt 1979). A detailed study was conducted on major ions from a Big Cypress Swamp alligator pond during a dry season. High concentrations of $\mathrm{Al}, \mathrm{Fe}, \mathrm{Mg}, \mathrm{Hg}$, $\mathrm{Pb}$ and $\mathrm{Zn}$ were found. Kushlan and Hunt determined that the high values were as results of reduced water volumes, rapid decomposition of animal and plant material, and reduction of bound compounds in anaerobic conditions. Rand and Schuler (2009) conducted a two-tier aquatic screening-level ecological risk assessment for several metals (As, $\mathrm{Cd}, \mathrm{Cr}, \mathrm{Cu}, \mathrm{Pb}, \mathrm{Ni}$, Zn) in sediment at 32 sites from the south Florida freshwater canals inside the Everglades. For tier 1, $\mathrm{As}, \mathrm{Cd}, \mathrm{Cr}, \mathrm{Cu}, \mathrm{Pb}, \mathrm{Ni}$ and $\mathrm{Zn}$ were identified as the metals of potential ecological concern (COPECs) as their concentrations have exceeded Florida sediment quality 
assessment Guideline (SQAG) at 10 sites. For tier 2, a probabilistic risk assessment method was used to compare distributions of predicted pore water exposure concentrations of seven metal COPECs with distributions of species response data from laboratory toxicity tests to quantify the likelihood of risk. Arsenic and $\mathrm{Cr}$ at sites surrounding the Everglades National Park were found to be the most frequently detected COPECs in sediment. Potential risks associated with $\mathrm{Pb}$ and $\mathrm{Cu}$ were estimated to be high. However, this study only set up about 20 sites around Everglades, most of which were at the boundary of Everglades. However, only 7 toxic metals were studied in Rand's research with goals to conduct a screening-level ecological risk assessment. Most studies associated with metals in the Everglades have focused on mercury because of its high toxicity to humans and its relatively high concentrations found in the Everglades ecosystem (Cai et al. 1999; Evans and Crumley 2005; Cohen et al. 2009). Cai et al. (1999) studied the interaction between organic C and Hg species in natural water in the Florida Everglades, and concluded Total $\mathrm{Hg}(\mathrm{THg})$ and Methyl $\mathrm{Hg}(\mathrm{MeHg})$ shared different distribution pattern in different phases. Furthermore, colloidal forms were found to contain most of THg, while MeHg is present almost exclusively in the lower molecular weight fraction of the colloid and in the truly dissolved fraction. Using stable isotopes of carbon, nitrogen, and sulfur measured in fish from the Florida Bay, Evans and Crumley (2005) concluded that $\mathrm{MeHg}$ and nutrient elements shared pathways through the food web, and the accumulation of $\mathrm{MeHg}$ sustained in gamefish supported by epibenthic feeders. Cohen and co-workers (2009) mapped soil total $\mathrm{Hg}$ concentrations per mass $\left(\mathrm{THg}_{\mathrm{M}}\right)$ and area $\left(\mathrm{THg}_{\mathrm{A}}\right)$ across the Everglades and predicted its spatial pattern. Sources of elevated THg including canal water from EAA and subsidence or oxidation of peal soil were proposed by the same group. 
Over the last two decades, several programs supported by federal and state agencies have been carried out to examine $\mathrm{Hg}$ pollution in the Everglades. For example, studies on $\mathrm{Hg}$ were conducted through the Regional Environmental Monitoring and Assessment Program (REMAP). Hg contamination was examined in terms of distribution among different matrices (water, mosquitofish, periphyton), and bioaccumulations (Scheidt and Kalla 2007). The goal of R-EMAP was to provide accurate and timely scientific information for management decisions on the restoration efforts in the Everglades (Scheidt and Kalla 2007). The Everglades R-EMAP area covers areas from north of Lake Okeechobee to the mangrove fringe on Florida Bay and from the ridge along the east coast to the west of Big Cypress National Preserve. The whole sample areas covers over 750 miles of canals and over 3,000 square miles of freshwater marsh. In May 2005 and November 2005, phase III of the program was conducted as samples were extracted from 228 Everglades marsh sites, covering marsh and canal locations throughout the freshwater Everglades and Big Cypress (Scheidt and Kalla 2007). Liu et al. (2008) analyzed samples from R-EMAP in 2005, and determined the concentrations for THg in the increasing order: periphyton $<$ floc $<$ soil. In addition, the same study concluded that condition for bioaccumulation of $\mathrm{Hg}$ is favored, on the basis of the distribution patterns of THg and MeHg (Liu et al. 2008). Bioaccumulation and spatial patterns in Hg cycling were then investigated, which lead to the identification of important factors (surface water dissolved organic matter $\left(\mathrm{DOC}_{\mathrm{sw}}, \mathrm{pH}\right.$, chloride, etc.) in controlling THg distribution (Liu et al. 2009). Using samples collected in both summer and winter seasons of 2005, mass inventories of $\mathrm{THg}$ and $\mathrm{MeHg}$ as well as mass budgets of $\mathrm{Hg}$ were constructed, in an effort to evaluate the magnitude of legacy Hg contamination and help predict the fate of new $\mathrm{Hg}$ in the Everglades area (Liu et al. 2011). Li and co-workers 
investigated the degradation of $\mathrm{MeHg}$ in the Everglades using stable isotope $\left(\mathrm{Me}^{201} \mathrm{Hg}\right)$ addition method. The study demonstrated that the degradation of MeHg can be attenuated by sunlight, a controlling factor in the distribution of MeHg in Everglades' water.

\subsection{Rationale and objectives of this study}

Most of the previous work done on metals in the Everglades has focused on $\mathrm{Hg}$, although other metals of environmental concerns deserve an equal share of the spotlight. The few studies that have been conducted for other metals rather than $\mathrm{Hg}$ in the Everglades have dealt with the assessment of eco-toxicity for a limited number of metals using data measured in Everglades' soil/sediment (Caccia et al. 2003; Carnahan et al. 2008; Rand and Schuler 2009). There is still a general lack of knowledge on the source, distribution, transport, and risk of metals in the Everglades.

Soil, flocculent materials (floc) and periphyton are three important components of the Everglades. Investigation of metal contamination in soil can help us assess the potential risk of metal pollution on aquatic organisms, and make efforts to prevent further deteriorations (Rand and Schuler 2009). Periphyton, an omnipresent feature of Everglades' marshes, is a community comprised of plants, algae and certain animals (MePherson and Halley 1996). It is responsible for almost half of primary production of the Everglades and serves as food source for small consumers like small fish, grass shrimp at the base of food chain (McCormick et al. 1996; Gaiser et al. 2006). Trace metals present in periphyton could enter higher trophic levels. Identification of metals in periphyton can help trace and estimate concentrations and source of metals in organisms higher up in the food chain. Flocculent material (floc), on the other hand, is composed of microorganisms, organic particles (detritus, cellular debris), inorganic particles (clays and silts) and pores (Neto et al. 2006). The 
important role played by floc in aquatic system lead to the belief that floc can dictate the fate and effect of particle-associated contaminates (Droppo 2001). In the Everglades, higher plant detritus, periphyton, carbonates, and remains of aquatic organisms in the freshwater and estuarine make up the floc (Neto et al. 2006). Floc also represents a significant part of food web for invertebrate and fish, and a thorough investigation of metal pollutions associated with it is essential to predict overall fate and source of trace metals in the Everglades ecosystem. A comprehensive study on metals in these important matrices (soil, periphyton and floc) is of great importance for a better understanding of the biogeochemical cycling of metals in the Everglades. Results of this study will also provide background information that is needed to aid the restoration effort set forth by the CERP.

The main objective of this research is to assess the current status of toxic and essential metals in the Florida Everglades. The following specific aims will be pursued in order to successfully accomplish this objective:

1. To determine the concentrations of 18 metals, including toxic metals ( $\mathrm{As}, \mathrm{Cd}, \mathrm{Cr}, \mathrm{Ni}$ and $\mathrm{Pb}$ ) and essential metals (Al, Ba, Be, $\mathrm{Co}, \mathrm{Cu}, \mathrm{Fe}, \mathrm{Li}, \mathrm{Mg}, \mathrm{Mn}, \mathrm{K}, \mathrm{Sr}, \mathrm{V}$ and $\mathrm{Zn}$ ) in various compartments (sediment, Floc, and periphyton) in the Florida Everglades.

2. To establish the spatial distribution pattern of the metals in the Everglades.

3. To quantify the major sources of the 18 metals present in the Everglades. 
2. Methods

2.1 Experimental section

\subsubsection{Sample collection}

Sampling covered the entire freshwater Everglades, including Arthur R. Marshall Loxahatchee National Wildlife Refuge (LNWR), water conservation area 2 (WCA-2), WCA3, and Everglades National Park (ENP). Soil, floc and periphyton were collected at 195 random located stations during the REMAP project in 2005 (Scheidt and Kalla 2007). Probability-based sampling design, adopted by the REMAP project was selected.

Soil samples were extracted with a 3-inch diameter clean polycarbonate coring tube to sample the top $10 \mathrm{~cm}$. The flocculent detrital material (floc) is the top layer of the soil is composed of suspended organic material containing mostly detritus from plants and algal inputs from periphyton (collected separately during soil sample collection. Three types of periphyton, floating mat (floating), soil mat (lying on the soil surface), and epiphytic (associating with macrophytes), were collected in the field. A layer of periphyton mat, if found on the top of the soil core, was separated and stored in a separate container. Samples in both dry and wet seasons (May and November 2005) were collected (Figure 2-1). All samples, soil, floc, and periphyton were stored in refrigerator at $-20^{\circ} \mathrm{C}$ before sample processing and analysis. 


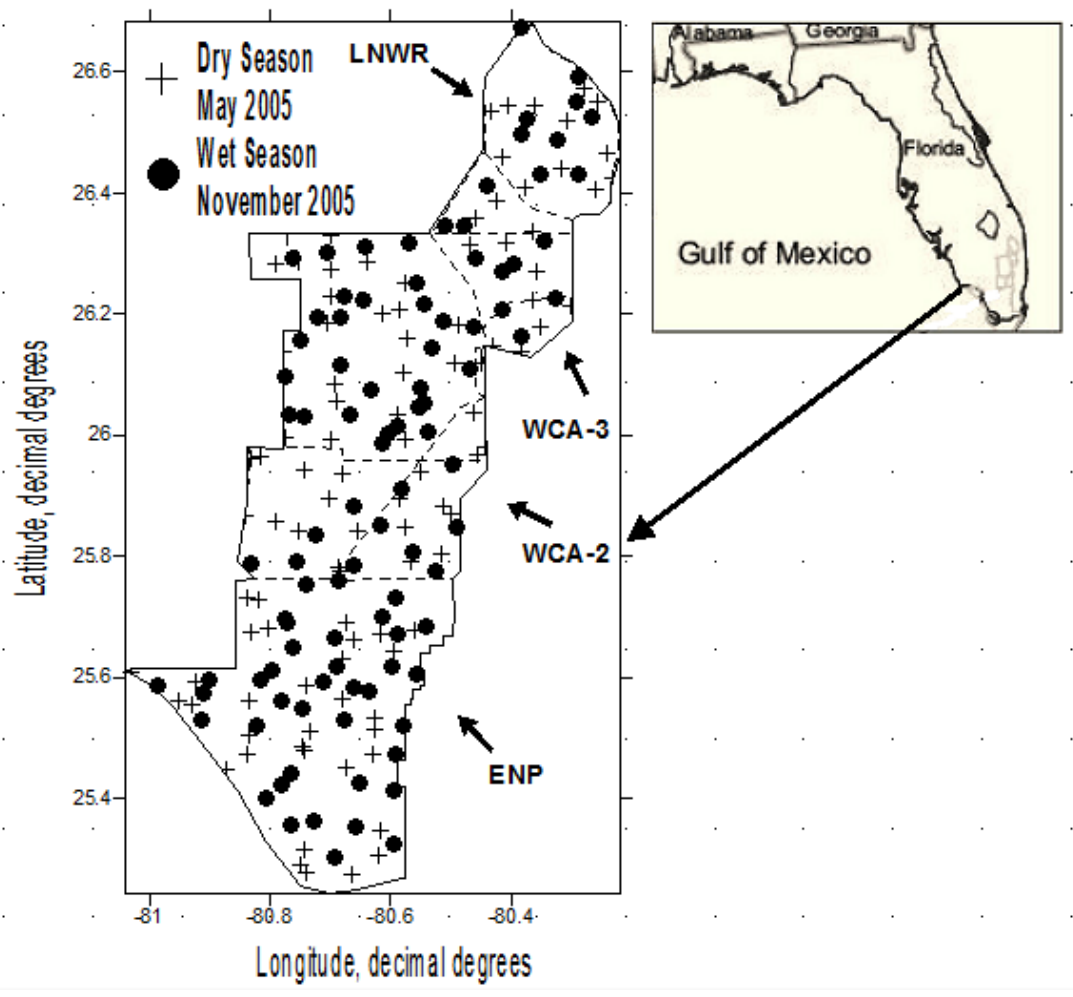

Figure 2-1 A map showing sampling sites in the Florida Everglades. Sites were sampled during the dry (May) and wet season (November). LNWR: Arthur R. Marshall Loxahatchee National Wildlife Refuge; WCA-2 and WCA-3: Water Conservation Areas; ENP: Everglades National Park

\subsubsection{Sample preparation and analysis}

Soil, floc, and periphyton samples were dried in the laboratory oven at $60 \mathrm{C}$ for four days, and then were homogenized using pestle and mortar. Approximately $0.5 \mathrm{~g}$ of each sample was transferred to a clean polypropylene digestion tube $(50 \mathrm{ml})$. Five $\mathrm{ml}$ concentrated nitric acid (trace metal grade) was added to each sample and the mixture was heated at $95 \pm$ $5^{\circ} \mathrm{C}$ on a hot block for an hour. After samples cooled to the room temperature, one $\mathrm{ml}$ of $30 \%$ hydrogen peroxide was added and then the samples were heated again at $95 \pm 5^{\circ} \mathrm{C}$ for 
additional 20 minutes. The samples were diluted with deionized water to $50 \mathrm{ml}$. Prior to analysis, samples were filtered $(0.2 \mu \mathrm{m}$ filter size $)$ and diluted on the basis of their concentrations (rough estimation for each metal analyzed). Twenty $\mu \mathrm{L}$ of yttrium was added to $10 \mathrm{ml}$ of sample solution to serve as the internal standard.

Concentrations of metals were analyzed using an ELAN DRC-E inductively coupled plasma-mass spectrometry system (ICP-MS). Personal Computer-based data acquisition and analysis software (ELAN version 3.4) was used.

Quality assurance/quality control (QA/QC) was taken to ensure data duplicity and highest accuracy possible. For every 20 samples prepared, two additional aliquots of one selected sample were spiked at the level of 1-5 times estimated concentration of metals in samples to serve as matrix spike and matrix spike duplicate (MS/MSD), along with two method blanks (containing only $2 \% \mathrm{HNO}_{3}(\mathrm{v} / \mathrm{v})$ and DIW) to assure quality and reliability of the analysis. For every 20 samples prepared, one sample was selected for triplicate analysis.

\subsubsection{Data analysis}

Concentrations of $\mathrm{Li}, \mathrm{Be}, \mathrm{V}, \mathrm{Mn}, \mathrm{Co}, \mathrm{Cu}, \mathrm{Tl}, \mathrm{Zn}, \mathrm{Sr}, \mathrm{Ba}, \mathrm{Al}, \mathrm{Fe}, \mathrm{K}, \mathrm{Mg}, \mathrm{As}, \mathrm{Cd}, \mathrm{Cr}$, $\mathrm{Ni}$ and $\mathrm{Pb}$ from all matrices collected in both dry and wet seasons were calculated on the basis of dry weight. Total recoverable analytes $(\mathrm{mg} / \mathrm{kg}$, dry weight basis) in solid samples were calculated for each sample analyzed using the equation below:

$\mathrm{C}_{\text {sample }}=\left(\mathrm{C}_{\text {extract }} \times \mathrm{V}_{\text {extract }}\right) / \mathrm{W}_{\text {dry }}$ 
Where $\mathrm{C}_{\text {sample }}$ is the concentration for total recoverable analyte; $\mathrm{C}_{\text {extract }}$ is the concentration of analyte in the extract $(\mathrm{mg} / \mathrm{L}) ; \mathrm{V}_{\text {extract }}$ is the volume of extract $(\mathrm{L}) ; \mathrm{W}_{\text {dry }}$ is the dry weight of sample aliquot extracted $(\mathrm{Kg})$.

Parameters, including maximum, minimum, standard deviation, and median values were calculated as well. Contour maps of each metal from both dry and wet seasons were plotted using SURFER. Pearson's correlation analyses of all metals were conducted intra and inter all matrices using Statistical Package for the Social Sciences (SPSS). The detection limits of ICP-MS techniques for all metals analyzed are listed in Table 2-1.

Table 2-1 Detection Limits of trace metals by ICP-MS

\begin{tabular}{llll}
\hline Element & $\begin{array}{l}\text { Detection Limit } \\
{[\mathrm{mg} / \mathrm{Kg}]}\end{array}$ & Element & $\begin{array}{l}\text { Detection Limit } \\
{[\mathrm{mg} / \mathrm{Kg}]}\end{array}$ \\
\hline $\mathrm{Al}$ & 0.2 & $\mathrm{Li}$ & 0.01 \\
$\mathrm{As}$ & 0.02 & $\mathrm{Mg}$ & 0.06 \\
$\mathrm{Ba}$ & 0.01 & $\mathrm{Mn}$ & 0.004 \\
$\mathrm{Be}$ & $\mathrm{Ni}$ & 0.01 \\
$\mathrm{Cd}$ & $\mathrm{K}$ & 0.3 \\
$\mathrm{Cr}$ & $\mathrm{Sr}$ & 0.001 \\
$\mathrm{Co}$ & 0.001 & $\mathrm{Tl}$ & 0.001 \\
$\mathrm{Cu}$ & 0.02 & $\mathrm{~V}$ & 0.05 \\
$\mathrm{Fe}$ & $\mathrm{Zn}$ & 0.2 \\
$\mathrm{~Pb}$ & 0.003 & & \\
\hline
\end{tabular}


3. Results

3.1 Metal concentrations in Florida Everglades soil, floc, and periphyton

All three matrices, soil, floc and periphyton, had different trends in terms of average concentrations and concentration ranges (Table 3.1 and 3.2). For soil samples, some metals $(\mathrm{Al}, \mathrm{Cu}, \mathrm{Ni}$ and $\mathrm{Pb})$ had higher concentrations in the dry season than in the wet season (Fig 31). Concentrations of $\mathrm{Be}, \mathrm{V}, \mathrm{Co}, \mathrm{Tl}, \mathrm{Zn}, \mathrm{Sr}, \mathrm{Ba}, \mathrm{Fe}, \mathrm{Mg}$ and $\mathrm{Cd}$ varied little during the year, while $\mathrm{Cr}$ and $\mathrm{K}$ was twice more concentrated in the wet season than in the dry season. The dry season also had a larger concentration ranges for most of metals than the wet season. Among all the metals, iron and Al had the highest concentrations in both dry and wet seasons. For floc samples, average concentrations varied significantly from dry season to wet season (Fig 3-2). Copper, $\mathrm{Mg}, \mathrm{Cr}, \mathrm{Ni}, \mathrm{Pb}$ had higher concentrations in the dry season compared to the wet season; $\mathrm{Li}, \mathrm{Co}, \mathrm{Tl}, \mathrm{Cd}$ and As had little concentration variations between seasons. Aluminum and $\mathrm{K}$ had higher mean concentrations in the wet season. Iron had the highest concentrations of all the metals analyzed. Mean concentration of almost all metals analyzed from periphyton varied little between seasons (Fig 3-3). Only $\mathrm{Be}, \mathrm{Al}, \mathrm{Fe}, \mathrm{Pb}, \mathrm{Cd}$ and $\mathrm{Zn}$ exhibited visible concentration changes. Aluminum and $\mathrm{Pb}$ had higher concentrations in the dry season while $\mathrm{Be}, \mathrm{Zn}, \mathrm{Cd}$, and Fe were more concentrated in the wet season. Other metals (Li, V, Mn, Co, Cu, Tl, Sr, Ba, Cr, Cd, Ni and As) had few changes in terms of mean concentrations. Similar to the other two compartments, iron is the most concentrated metal in periphyton. As for the distribution of metals among different compartments, average concentrations of most metals follow the order of soil $>$ floc $>$ periphyton, except for $\mathrm{Mn}, \mathrm{Sr}$, $\mathrm{Ba}, \mathrm{K}, \mathrm{Ni}, \mathrm{Cu}$ and $\mathrm{Zn}$. Floc had the highest concentrations of $\mathrm{Cu}$ and $\mathrm{Zn}$ while periphyton had the most concentrated values for $\mathrm{Mn}, \mathrm{Sr}, \mathrm{Ba}, \mathrm{K}$ and $\mathrm{Ni}$. Aluminum and $\mathrm{Fe}$ had the 
highest concentrations among all metals from sediment samples in both dry season (May 2005) and wet season (November 2005), while $\mathrm{Tl}$ was the least concentrated metal.

Table 3-1 Average concentrations of metals in all matrices (soil, floc, and periphyton) in dry season $(\mathrm{mg} / \mathrm{kg}$ for all metals except for $\mathrm{Al}, \mathrm{Fe}$ and $\mathrm{Mg}$ given in $(\mathrm{mg} / \mathrm{g}))$

\begin{tabular}{lllllll}
\hline Metals & Soil & & Floc & \multicolumn{3}{l}{ Periphyton } \\
\hline Lithium & Mean & Range & Mean & Range & Mean & Range \\
Beryllium & $0.096 \pm 0.109$ & $0.002-0.542$ & $0.07 \pm 0.05$ & $0.001-0.3$ & $0.03 \pm 0.52$ & $0.10-1.90$ \\
Vanadium & $12.23 \pm 9.76$ & $2.40-70.1$ & $7.75 \pm 6.8$ & $0.32-37.0$ & $2.32 \pm 1.89$ & $0.01-0.09$ \\
Manganese & $92.0 \pm 72.1$ & $1.40-363$ & $138 \pm 94.7$ & $16.9-411$ & $586 \pm 570$ & $83.2-1,883$ \\
Cobalt & $0.675 \pm 0.340$ & $0.013-1.72$ & $1.13 \pm 0.41$ & $0.45-2.16$ & $0.68 \pm 0.26$ & $0.24-1.19$ \\
Copper & $6.10 \pm 10.8$ & $0.161-71$ & $17.8 \pm 22.4$ & $2.76-120$ & $4.07 \pm 6.02$ & $0.56-24.0$ \\
Thallium & $0.027 \pm 0.0230$ & $0.001-0.166$ & $0.013 \pm 0.012$ & $0.001-0.087$ & $0.006 \pm 0.01$ & $0.001-0.02$ \\
Zinc & $7.15 \pm 4.87$ & $0.013-26$ & $19.9 \pm 8.82$ & $5.77-59.8$ & $7.16 \pm 4.10$ & $2.42-16.8$ \\
Strontium & $360 \pm 224$ & $13.1-1098$ & $367 \pm 331$ & $20.3-2301$ & $602 \pm 480$ & $150-1,890$ \\
Barium & $42.9 \pm 15.8$ & $12.6-87.5$ & $49.1 \pm 12.4$ & $26.7-84.7$ & $65.0 \pm 50.1$ & $26.1-215$ \\
Aluminum & $4.12 \pm 5,26$ & $.328-46.3$ & $.706 \pm .750$ & $0.015-4.76$ & $1.27 \pm 1,69$ & $0.051-4,84$ \\
Iron & $6,10 \pm 5,04$ & $.602-25.9$ & $5.50 \pm 5.31$ & $0.037-27.1$ & $4.27 \pm 4,11$ & $.242-14.8$ \\
Potassium & $157 \pm 86.2$ & $2.17-368$ & $395 \pm 326$ & $39-2,25$ & $522 \pm 338$ & $186-1,251$ \\
Magnesium & $2.11 \pm 1.86$ & $.0676-17.2$ & $2.24 \pm 1.43$ & $.166-7.59$ & $2.66 \pm 2,04$ & $.240-7.28$ \\
Chromium & $4.28 \pm 4.93$ & $0.065-30.6$ & $5.89 \pm 3.70$ & $2.00-17.9$ & $1.95 \pm 1.31$ & $0.59-5.44$ \\
Nickel & $4.87 \pm 3.83$ & $0.383-19.6$ & $9.35 \pm 7.71$ & $3.51-39.1$ & $16.5 \pm 8.63$ & $4.05-33.7$ \\
Arsenic & $2.82 \pm 1.97$ & $0.142-8.41$ & $4.41 \pm 2.45$ & $0.84-13.7$ & $1.26 \pm 1.00$ & $0.22-4.06$ \\
Cadmium & $0.118 \pm 0.127$ & $0.004-1.07$ & $0.114 \pm 0.108$ & $0.01-0.78$ & $0.03 \pm 0.02$ & $0.01-0.08$ \\
Lead & $18.5 \pm 38.5$ & $0.122-280$ & $2.67 \pm 4.12$ & $0.05-19.3$ & $0.87 \pm 1.29$ & $0.02-4.74$ \\
\hline
\end{tabular}


Table 3-2 Average concentrations of metals in all matrices (soil, floc, and periphyton) in wet season $(\mathrm{mg} / \mathrm{kg}$ for all metals except for $\mathrm{Al}, \mathrm{Fe}$ and $\mathrm{Mg}$ given in $(\mathrm{mg} / \mathrm{g}))$

\begin{tabular}{lllllll}
\hline Metals & Soil & & Floc & \multicolumn{3}{c}{ Periphyton } \\
\hline & Mean & Range & Mean & Range & Mean & Range \\
Lithium & $1.27 \pm 1.65$ & $0.064-10.3$ & $0.80 \pm 0.94$ & $0.17-5.72$ & $0.50 \pm 0.51$ & $0.09-1.75$ \\
Beryllium & $0.084 \pm 0.064$ & $0.007-0.395$ & $0.42 \pm 0.31$ & $0.01-1.55$ & $0.09 \pm 0.09$ & $0.02-0.38$ \\
Vanadium & $11.8 \pm 7.17$ & $1.35-43.6$ & $11.2 \pm 7.18$ & $2.99-32.9$ & $3.23 \pm 1.91$ & $1.21-9.87$ \\
Manganese & $67.7 \pm 46.5$ & $7.09-197$ & $371 \pm 412$ & $17.8-2,278$ & $532 \pm 484$ & $86.9-1,881$ \\
Cobalt & $0.82 \pm 1.1$ & $0.14-8.96$ & $1.07 \pm 0.40$ & $0.43-2.70$ & $0.86 \pm 0.36$ & $0.43-1.67$ \\
Copper & $2.89 \pm 2.02$ & $0.127-9.97$ & $7.39 \pm 4.91$ & $2.54-30.8$ & $4.36 \pm 4.95$ & $0.68-20.3$ \\
Thallium & $0.025 \pm 0.041$ & $0.001-0.264$ & $0.016 \pm 0.01$ & $0.004-0.059$ & $0.01 \pm 0.02$ & $0.001-0.11$ \\
Zinc & $7.29 \pm 4.95$ & $0.404-20.9$ & $16.7 \pm 6.62$ & $6.05-35.2$ & $12.6 \pm 7.79$ & $3.06-30.4$ \\
Strontium & $346 \pm 205$ & $60.0-856$ & $391 \pm 308$ & $76.8-1,579$ & $543 \pm 405$ & $81.9-1,976$ \\
Barium & $43.3 \pm 17.6$ & $9.07-95$ & $68.5 \pm 39.0$ & $24.1-227$ & $67.0 \pm 41.2$ & $18.7-171$ \\
Aluminum & $3.08 \pm 4.30$ & $0.051-21.9$ & $1.13 \pm 1.59$ & $0.058-9.96$ & $0.494 \pm 0.580$ & $0.070-2.97$ \\
Iron & $6.16 \pm 3.99$ & $0.808-20.9$ & $5.98 \pm 4.77$ & $0.524-19.5$ & $5.86 \pm 4.68$ & $0.770-17.5$ \\
Potassium & $335 \pm 225$ & $1.9-958$ & $570 \pm 591$ & $97-4294$ & $742 \pm 511$ & $140-1,988$ \\
Magnesium & $2.04 \pm 1.61$ & $0.0071-13.4$ & $0.961 \pm 0.864$ & $0.127-4.26$ & $2.07 \pm 1.61$ & $0.340-7.04$ \\
Chromium & $12.1 \pm 15.2$ & $1.80-59.8$ & $3.08 \pm 1.26$ & $1.31-9.15$ & $1.62 \pm 0.92$ & $0.62-4.15$ \\
Nickel & $3.423 \pm 2.03$ & $1.06-13.0$ & $3.37 \pm 1.63$ & $1.31-11.12$ & $17.7 \pm 10.9$ & $4.82-46.8$ \\
Arsenic & $3.13 \pm 2.77$ & $0.074-14.9$ & $3.39 \pm 1.91$ & $0.49-8.74$ & $2.12 \pm 1.79$ & $0.38-7.17$ \\
Cadmium & $0.12 \pm 0.12$ & $0.007-0.83$ & $0.092 \pm 0.033$ & $0.022-0.186$ & $0.07 \pm 0.15$ & $0.01-0.99$ \\
Lead & $1.27 \pm 1.65$ & $0.24-146$ & $0.80 \pm 0.94$ & $0.37-21.6$ & $0.50 \pm 2.88$ & $0.02-12.2$ \\
\hline
\end{tabular}




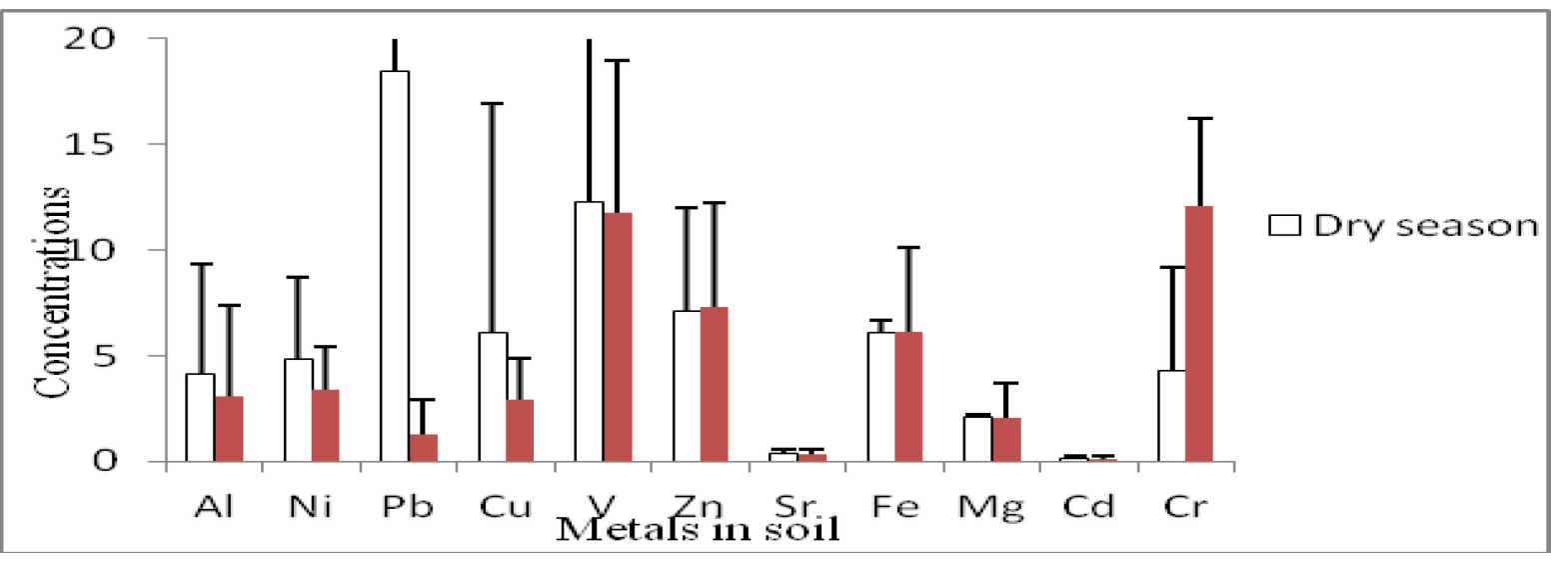

Figure 3-1 Comparison of metal concentrations from soil in dry and wet season

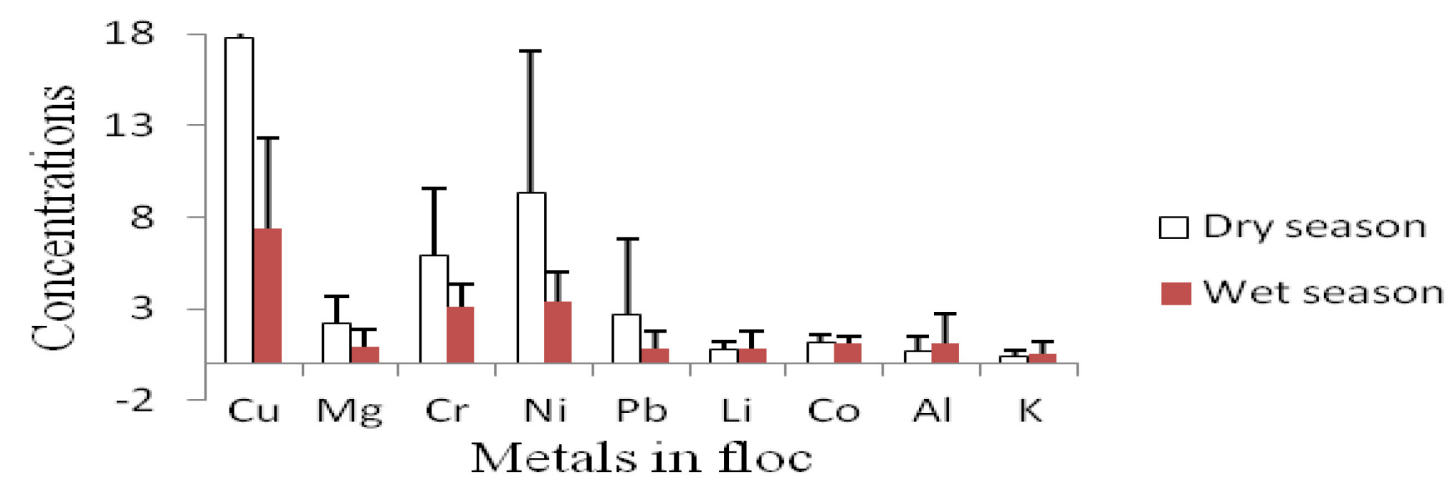

Figure 3-2 Comparison of metal concentrations from floc in dry and wet season

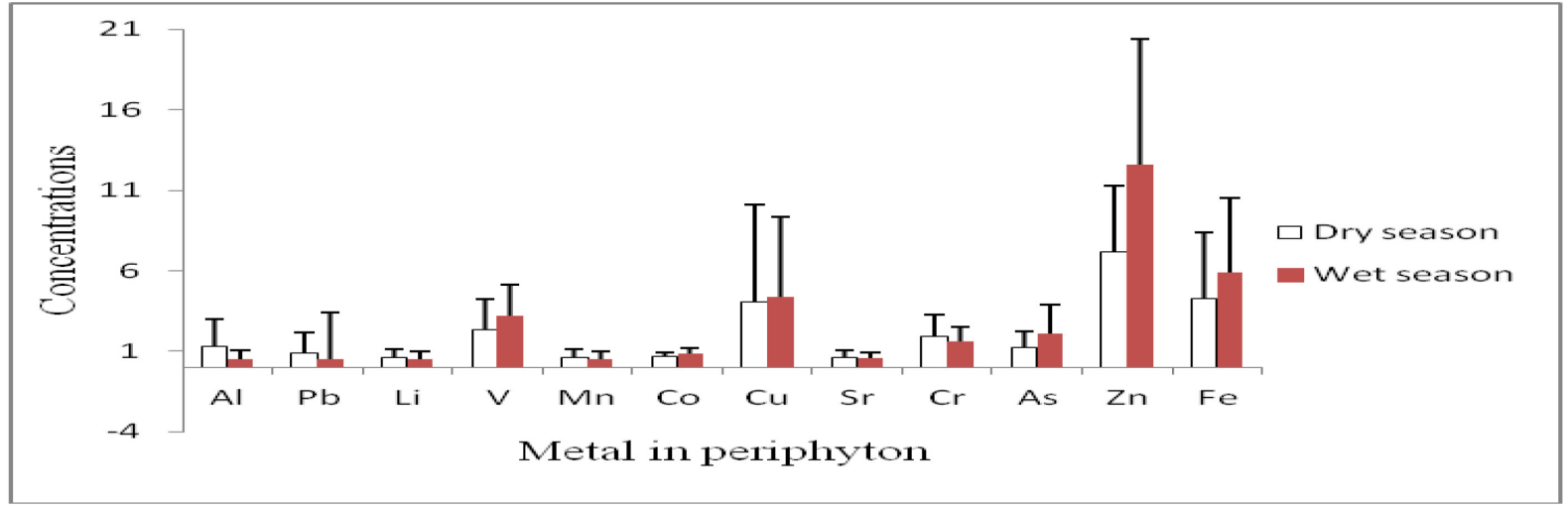

Figure 3-3 Comparison of metal concentrations from periphyton in dry and wet season 
Correlation matrixes for metals present in the three compartments are shown in Tables 3.3, 3.4, and 3.5. Between soil and periphyton metals, soil metals (Mn, As, Cd and Zn) and periphyton metal $(\mathrm{Zn})$ were significantly correlated. Periphyton $\mathrm{Sr}$ and $\mathrm{Mg}$ had strong correlation with soil metals $(\mathrm{Co}, \mathrm{Cu}, \mathrm{Cd}, \mathrm{Tl}, \mathrm{Pb}$ and $\mathrm{Sr}$ ) (Table 3.3). Between soil and floc metals, $\mathrm{Cr}$ in soil correlated well with $\mathrm{Tl}$ and $\mathrm{Pb}$ in floc. Soil metals (Ni and $\mathrm{As}$ ) correlated with floc metals ( $\mathrm{Sr}$ and $\mathrm{Fe}$ ), respectively (Table 3.4). Between floc and periphyton, periphyton metal Ni correlated well with floc metal Zn. Strontium in periphyton correlated significantly with $\mathrm{Sr}, \mathrm{Ba}$ and $\mathrm{Mg}$ in floc (Table 3.5). 
Table 3-3 correlation matrix of metals (soils, $\mathrm{x}$ axis) versus periphyton ( $\mathrm{y}$ axis)

Metals in soil

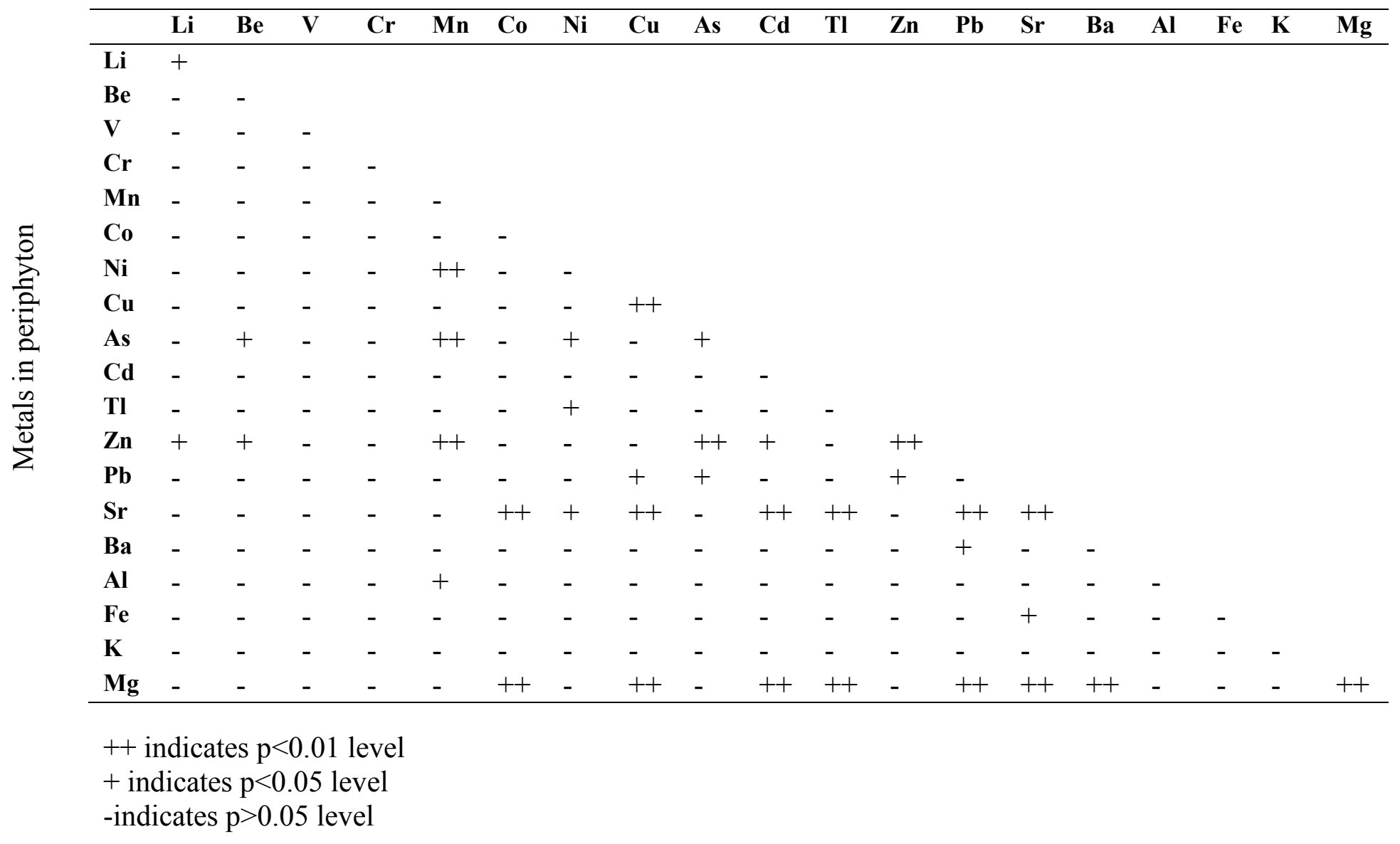


Table 3-4 Correlation matrix of metals (soils, $\mathrm{x}$ axis) versus floc (y axis)

metals in soil

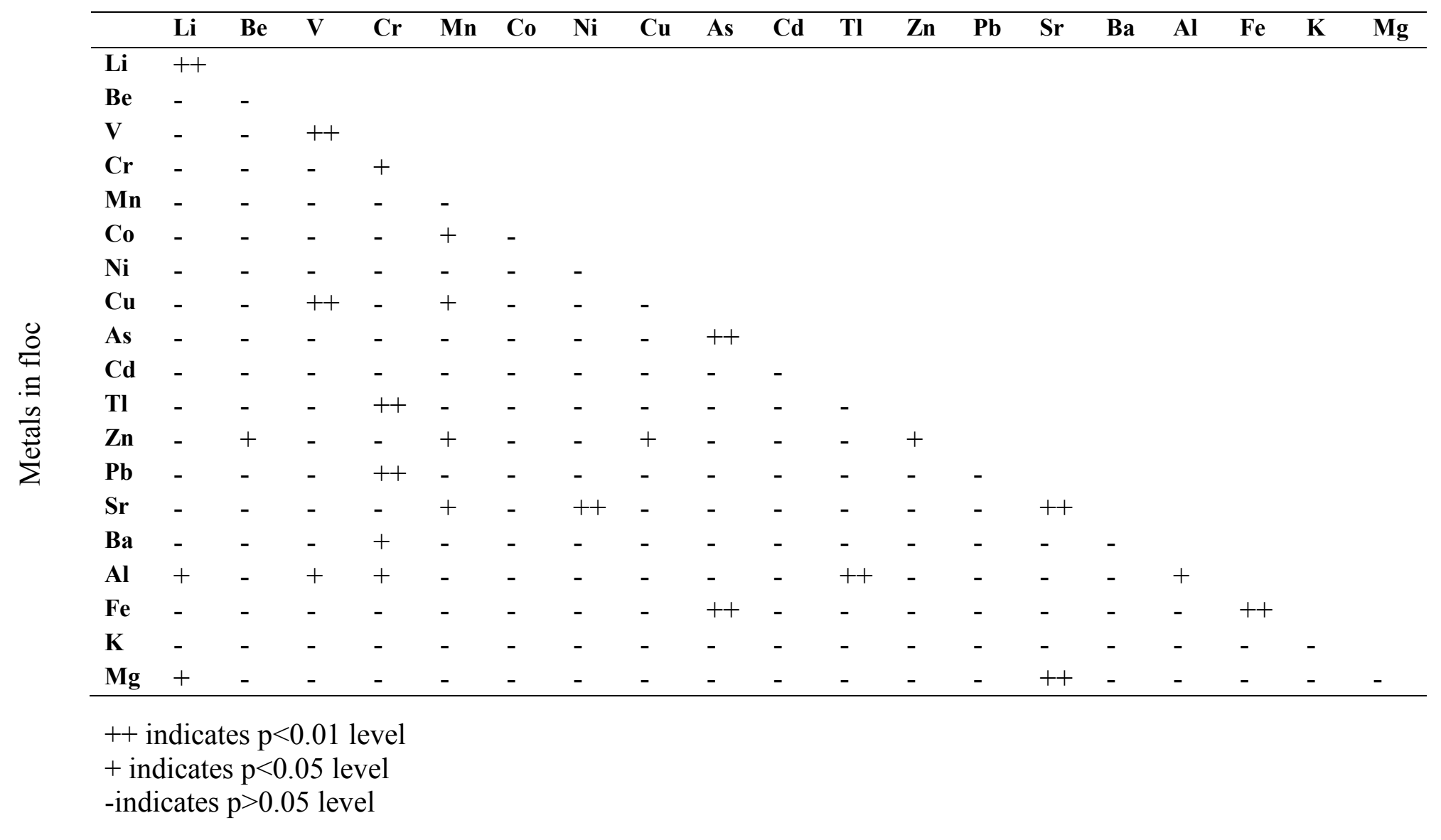


Table 3-5 correlation matrix of metals (floc, $\mathrm{x}$ axis) versus periphyton (y axis)

Metals in floc

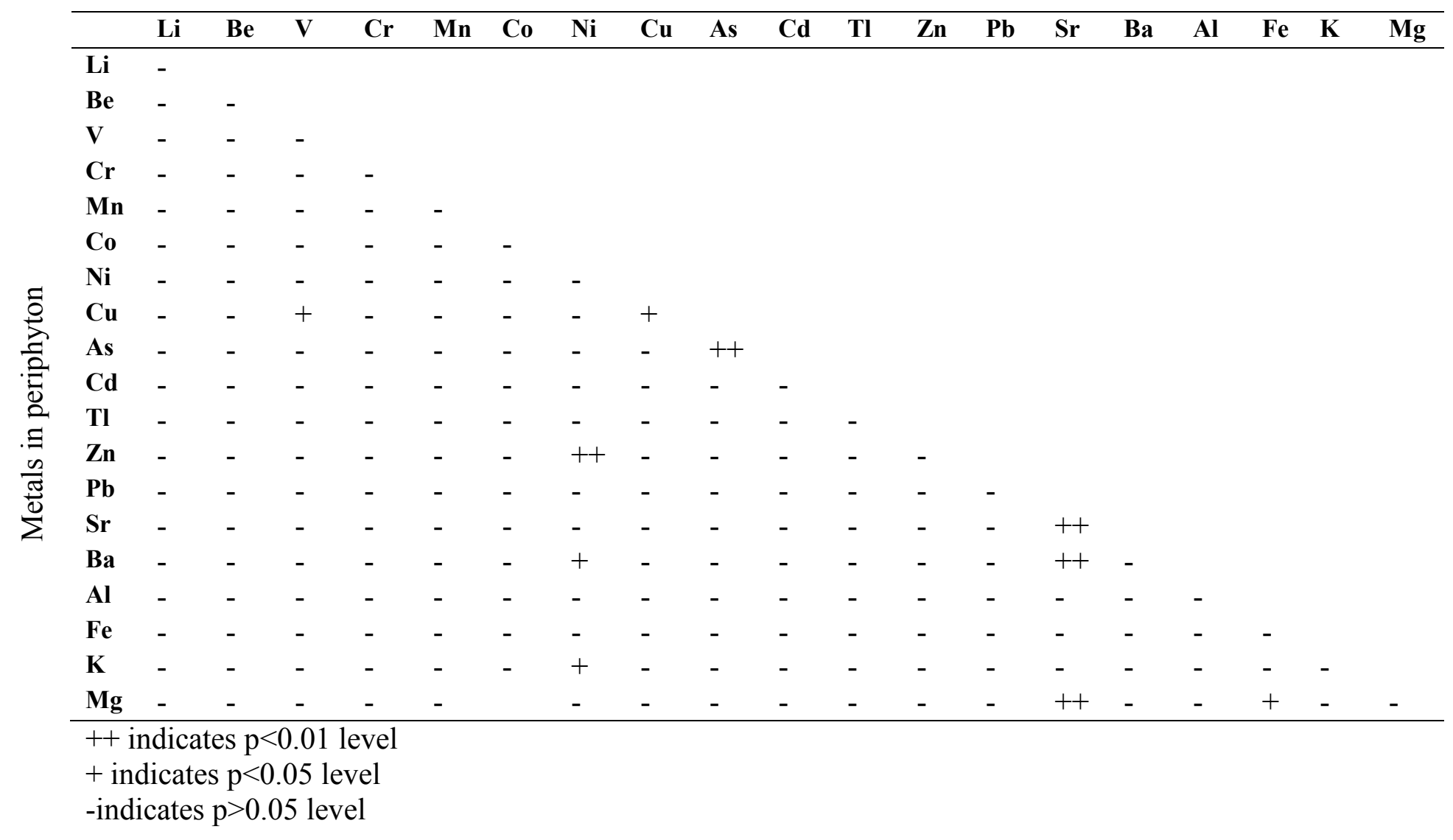


3.2 Spatial distribution of metals in Everglades soil, floc and periphyton

\subsubsection{Spatial distribution of metals in soil}

Spatial distribution patterns of toxic metals $(\mathrm{Cd}, \mathrm{Cr}, \mathrm{Ni}, \mathrm{As}$ and $\mathrm{Pb})$ in soil were grouped together (Fig 3.4 -3.6). Although $\mathrm{Cu}$ and $\mathrm{Zn}$ are considered toxic at high concentrations, the two were mixed with essential metals because 1) those two metals are essential to plants and other organisms at low concentrations; 2) average concentrations of $\mathrm{Cu}$ and $\mathrm{Zn}$ from all matrices were low.

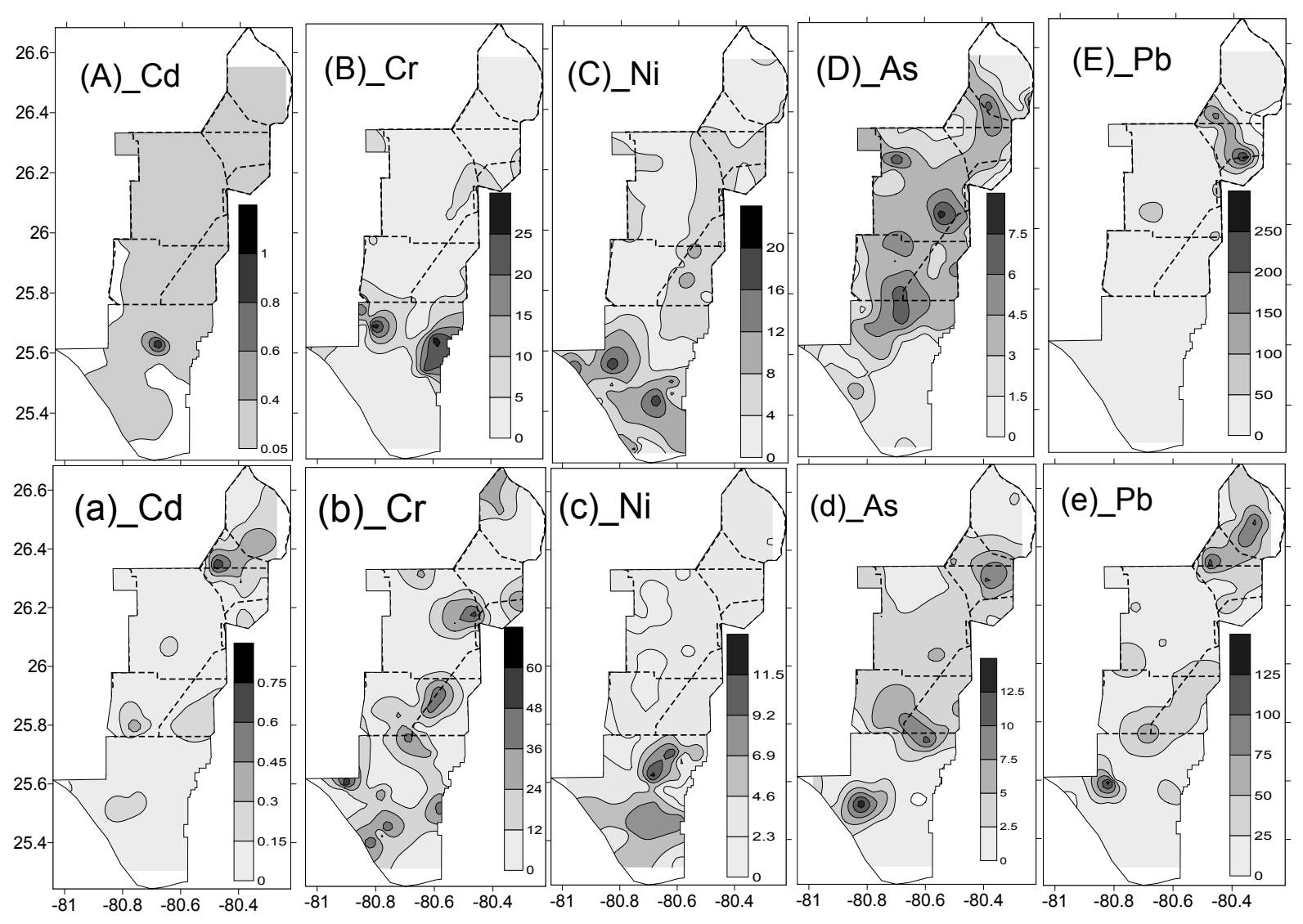

Figure 3-4 Spatial variation of toxic metals in soils of the Florida Everglades (A) Cd, (B) Cr, (C) $\mathrm{Ni}$, (D) As, and (E) Pb during the dry season (Top, labeled with capital letters) and wet season (bottom, labeled with lowercase letters). 


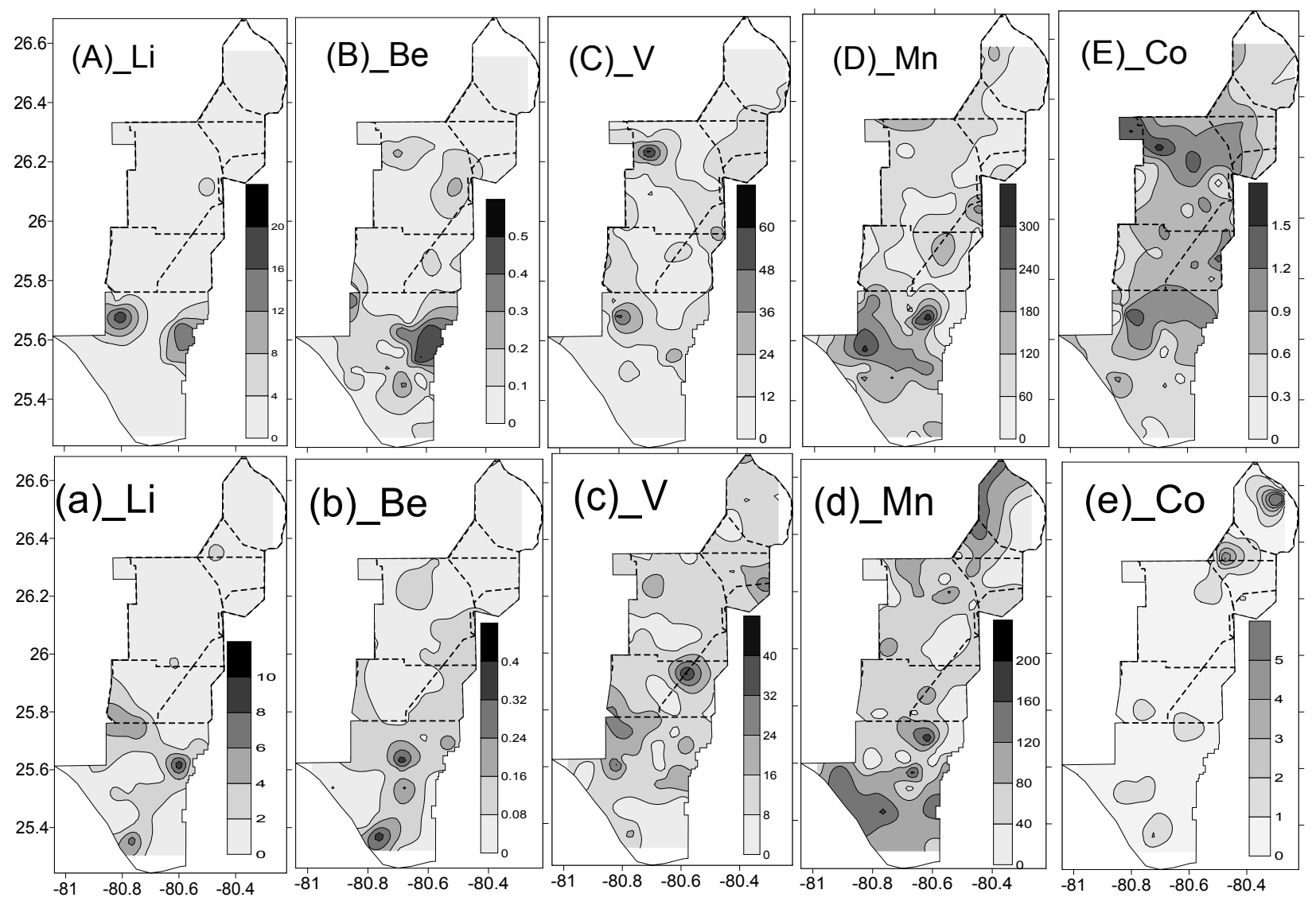

Figure 3-5 Spatial variation of essential metals in soils of the Florida Everglades (A) Li, (B) Be, (C) V, (D) Mn, and (E) Co during the dry season (Top, labeled with capital letters) and wet season (bottom, labeled with lowercase letters). 

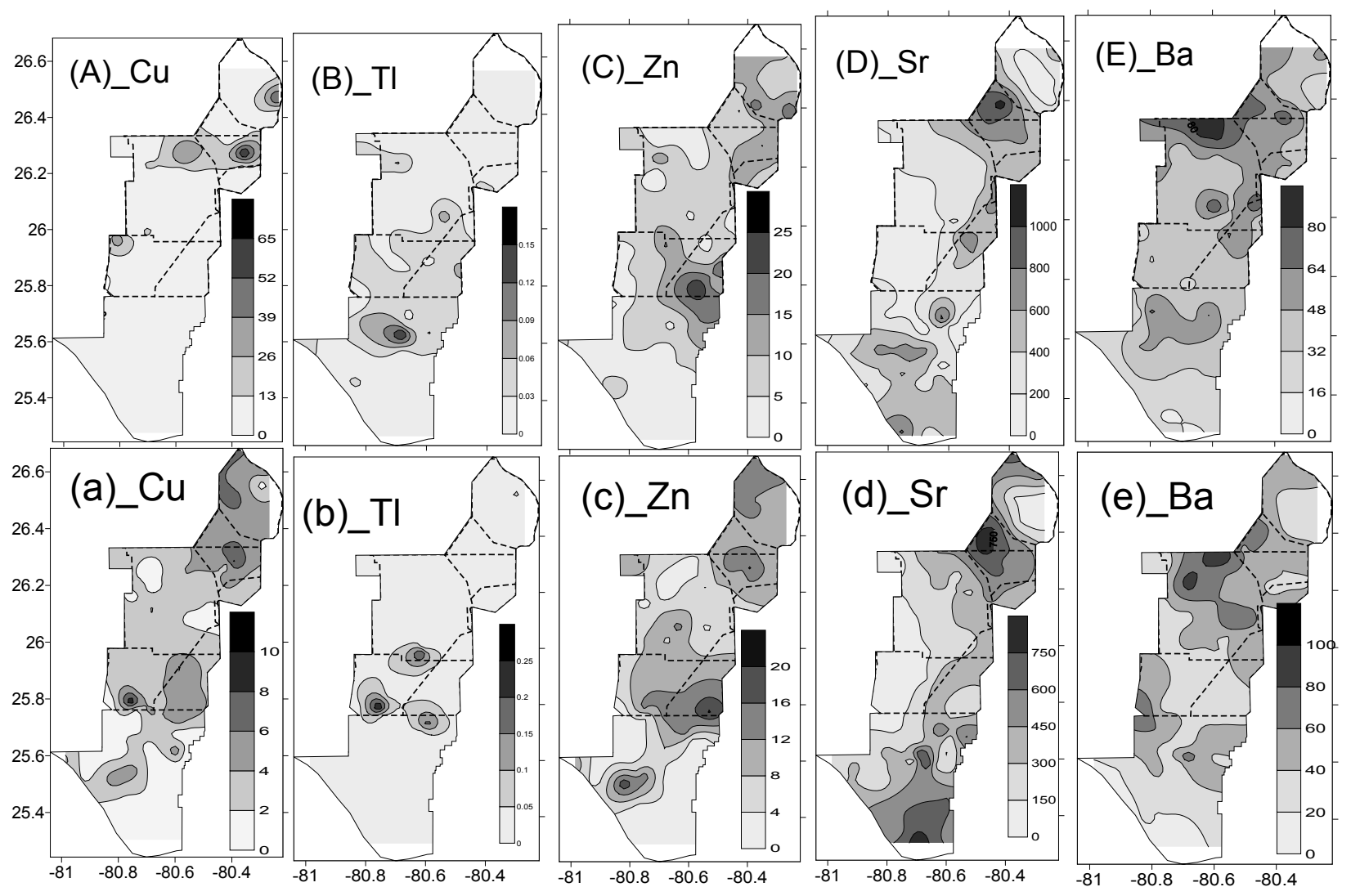

Figure 3-6 Spatial variation of essential metals in soils of the Florida Everglades (A) Cu, (B) Tl, (C) Zn, (D) Sr, and (E) Ba during the dry season (Top, labeled with capital letters) and wet season (bottom, labeled with lowercase letters). 

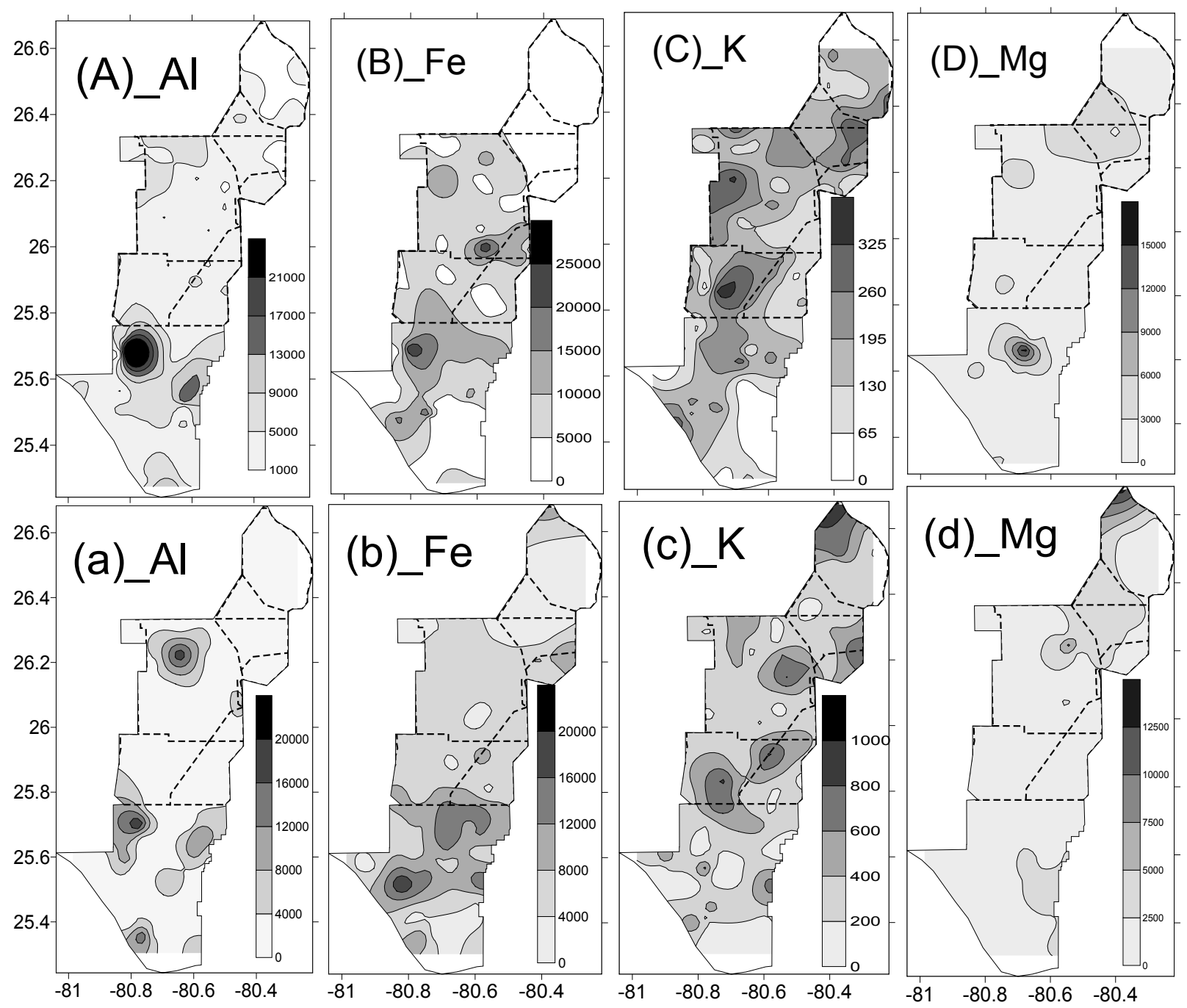

Figure 3-7 Spatial variation of essential metals in soils of Florida Everglades (A) Al, (B) Fe, (C) $\mathrm{K}$ and (D) Mg during the dry season (Top, labeled with capital letters) and wet season (bottom, labeled with lowercase letters). 
Spatial distributions of metals in soils from both seasons are very complex. For example, $\mathrm{Sr}$ decreased in concentration from east to west, while $\mathrm{Pb}$ and $\mathrm{Ba}$ decreased in concentration from north to south (Fig 3-4). In the dry season, hot spots, defined as areas where significantly higher concentrations of metals are observed, were mainly observed in several distinctive areas of LNWR, WCA-2, WCA-3, and ENP (Fig 3-4 through Fig 3-7). Maximum concentrations were observed in the western area of ENP for $\mathrm{Li}, \mathrm{Be}, \mathrm{V}, \mathrm{Mn}, \mathrm{Co}$, $\mathrm{Tl}, \mathrm{Al}, \mathrm{Fe}, \mathrm{Cd}, \mathrm{Cr}$, and $\mathrm{Ni}$; WCA-2 for $\mathrm{Cu}, \mathrm{Sr}, \mathrm{Pb}$, and $\mathrm{Ba}$; eastern area of ENP for $\mathrm{Li}, \mathrm{Be}, \mathrm{V}$, $\mathrm{Mn}$, and $\mathrm{Zn}$; northern area of ENP for Mg. The highest concentration of As was found in the northern area of WCA-3 near the Tamiami Trail. There is no distinctive pattern presented for $\mathrm{K}$. In terms of minimum concentrations, all metals except for $\mathrm{Cu}, \mathrm{Sr}, \mathrm{Ba}$, and $\mathrm{K}$ had cold spots located in Loxahatchee National Wildlife Refuge. The least concentrated samples containing $\mathrm{Cu}$ and $\mathrm{Ba}$ were extracted from south of ENP, while least concentrated $\mathrm{Sr}$ samples came from western area of WCA-3.

The distribution patterns in the wet season were similar to those in the dry season. Some essential metals ( $\mathrm{Li}, \mathrm{V}, \mathrm{Tl}, \mathrm{As}, \mathrm{Pb}, \mathrm{Al}$, and $\mathrm{Fe}$ ) were observed to have hot spots and cold spots in the same locations where the maximum and minimum concentrations occurred in the dry season (Fig 3-4 through Fig 3-7). Hot spots were seen in the western area for Li, V, $\mathrm{Cu}, \mathrm{Tl}, \mathrm{Ba}, \mathrm{Al}$, and $\mathrm{Fe}$, WCA-2 for $\mathrm{Cu}, \mathrm{Pb}, \mathrm{Sr}$, and $\mathrm{Ba}$, northeastern area of ENP for $\mathrm{Be}, \mathrm{Li}$ and $\mathrm{V}$, and $\mathrm{Zn}$; $\mathrm{LNWR}$ for $\mathrm{Cd}, \mathrm{Cr}, \mathrm{Pb}, \mathrm{Mg}$ and $\mathrm{Co}$. The distribution pattern was ambiguous for K and Mn. Minimum concentrations were detected in LNWR for all metals except for Co, $\mathrm{Cu}, \mathrm{Zn}, \mathrm{Sr}, \mathrm{Ba}$, and Magnesium. Cobalt, $\mathrm{Cu}, \mathrm{Zn}, \mathrm{Ba}$ and $\mathrm{Mg}$ had the lowest concentrations in 
the southern part of ENP, whereas the lowest concentrated samples in $\mathrm{Sr}$ and Ba were spotted in the western area of Water Conservation Area-3.

\subsubsection{Spatial distribution of metals in the Florida Everglades floc}

Distributions of metals in floc were group in the same way as did the soil. Dry season and wet season had drastically different spatial patterns. In dry season, concentrations of $\mathrm{Pb}$, $\mathrm{Sr}$ and $\mathrm{Mg}$ attenuated from north to south (Fig 3-8, 3-9 and 3-10). Other metals had more complex spatial distribution patterns. Several regions covered with highly concentrated metals in floc samples. The distribution of metals had hot spots in western area of WCA-3 for $\mathrm{Li}, \mathrm{Be}, \mathrm{V}, \mathrm{Cr}, \mathrm{As}, \mathrm{Mn}, \mathrm{Co}, \mathrm{Cu}, \mathrm{Tl}$ and $\mathrm{Al}$ and WCA-2 for Sr, Ba, Ni and Magnesium (Fig 3-7 through Fig 3-10). Zn and Ba had the lowest concentrations in the mid region of Water Conservation Area-3.

In wet season, concentrations of $\mathrm{Mn}, \mathrm{Sr}, \mathrm{K}$ and $\mathrm{Mg}$ decreased from north towards south (Fig 3-9, 3-10 and 3-11). Chromium, As, and $\mathrm{Pb}$ were similarly distributed as in the dry season. Several metals, including $\mathrm{Li}, \mathrm{Be}, \mathrm{Mn}, \mathrm{Sr}$, and $\mathrm{Mg}$, had the highest concentration discovered in the eastern area of WCA-3, whereas western area of WCA-3 contained maximum concentrations of $\mathrm{V}, \mathrm{Co}, \mathrm{Cu}, \mathrm{Tl}, \mathrm{Zn}, \mathrm{Fe}$, and $\mathrm{K}$ (Fig 3-9 through Fig 3-11). On the other end of spectrum, the minimum concentrations of $\mathrm{Li}$ and Be were located in the western zone of Water Conservation Area-3. The south of ENP contained least concentrated of some metals including $\mathrm{Mn}, \mathrm{Cu}, \mathrm{Zn}, \mathrm{Sr}, \mathrm{Mg}$ and Barium. Western area of the ENP and eastern area of WCA-3 contained minimum concentrations of $\mathrm{V}, \mathrm{Cu}, \mathrm{Tl}, \mathrm{Al}, \mathrm{Fe}$ and Cobalt. 

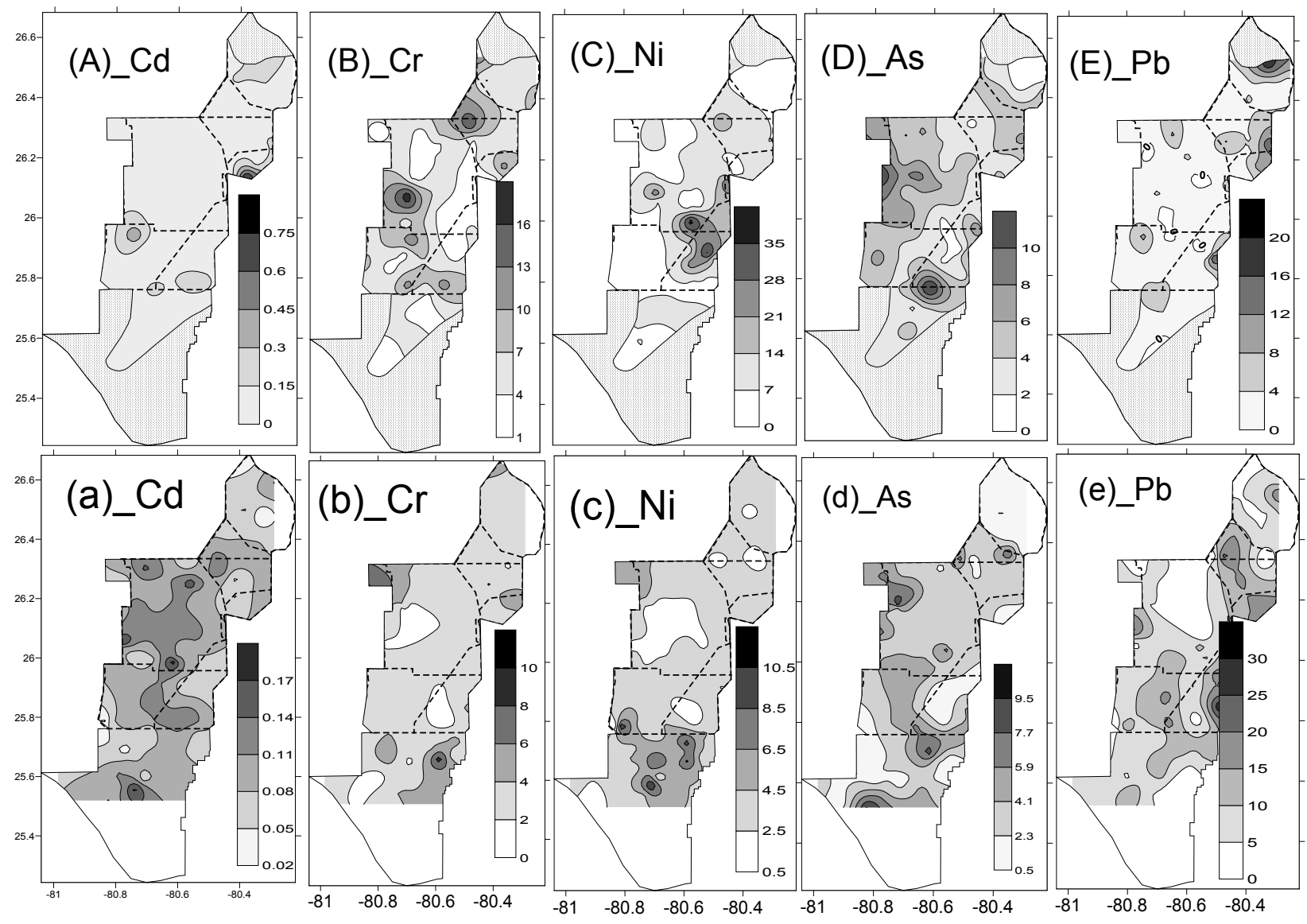

Figure 3-8 Spatial variation of toxic metals in floc of the Everglades (A) Cd, (B) $\mathrm{Cr},(\mathrm{C}) \mathrm{Ni}$, (D) $\mathrm{As}$, and (E) $\mathrm{Pb}$ during the dry season (Top, labeled with capital letters) and wet season (bottom, labeled with lowercase letters). 


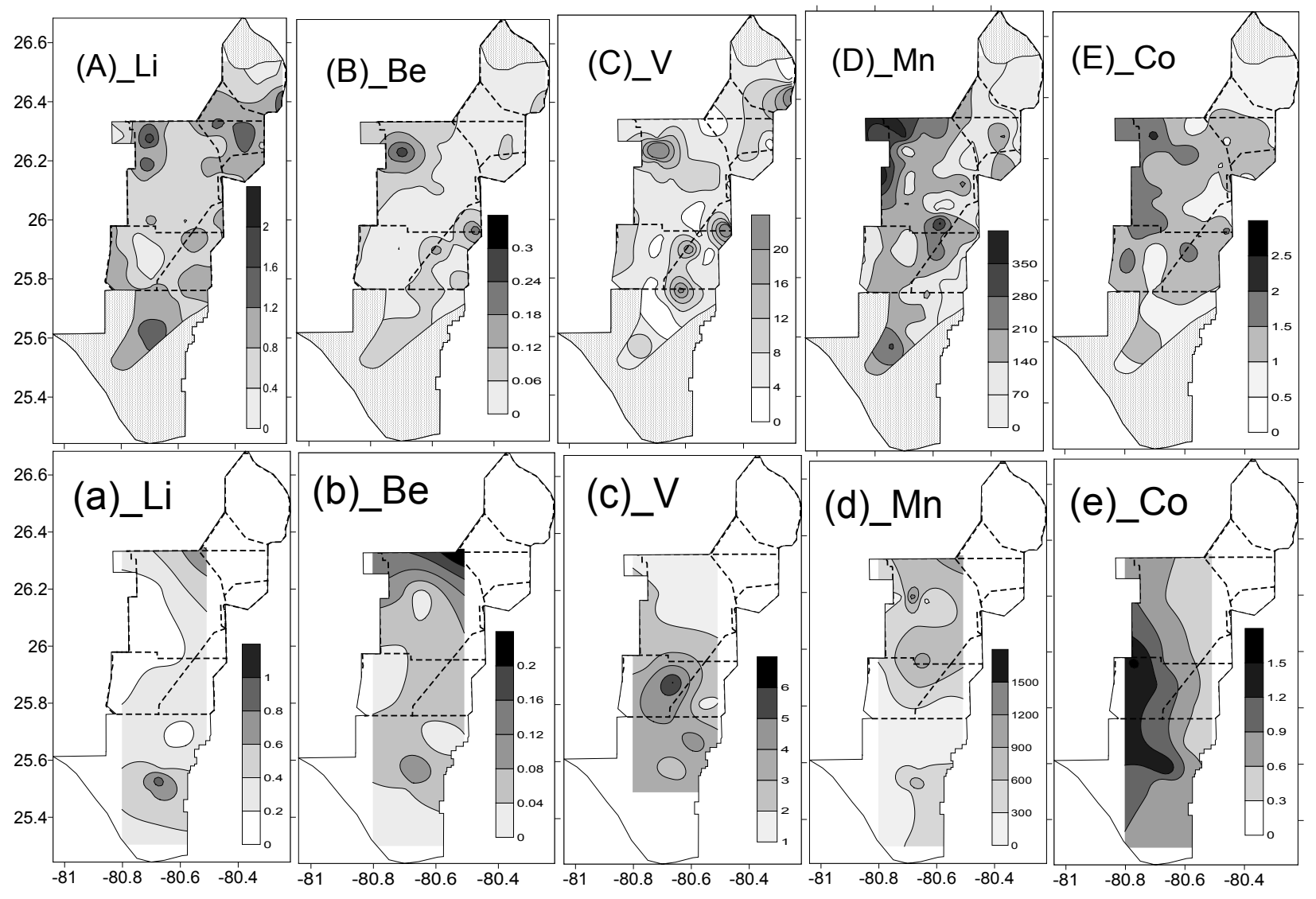

Figure 3-9 Spatial variation of essential metals in floc of Florida Everglades (A) Li, (B) Be, (C) V, (D) Mn, and (E) Co during the dry season (Top, labeled with capital letters) and wet season (bottom, labeled with lowercase letters). 


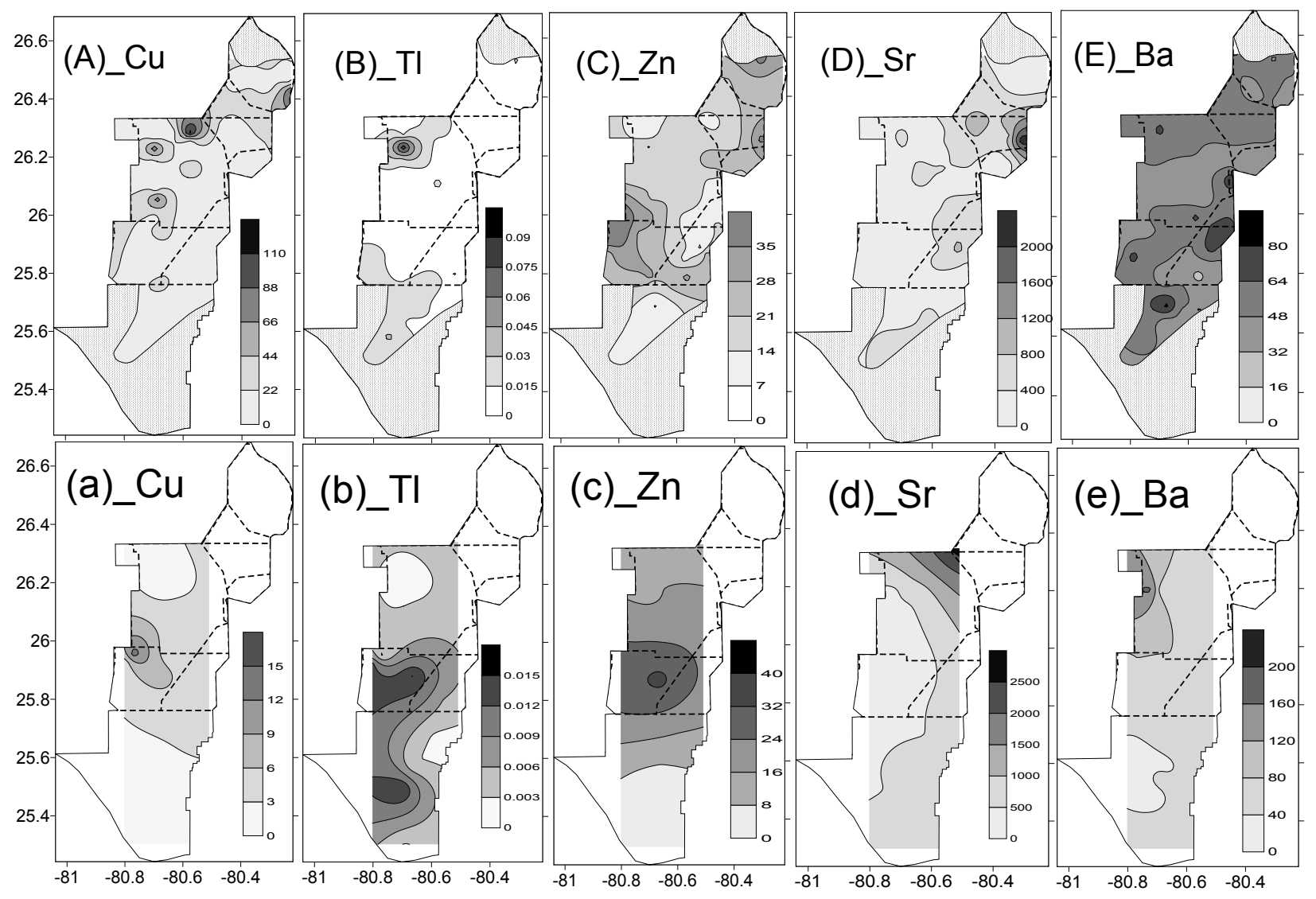

Figure 3-10 Spatial variation of essential metals in floc of Florida Everglades (A) $\mathrm{Cu},(\mathrm{B}) \mathrm{Th}$, (C) Zn, (D) Sr, and (E) Ba during the dry season (Top, labeled with capital letters) and wet season (bottom, labeled with lowercase letters). 


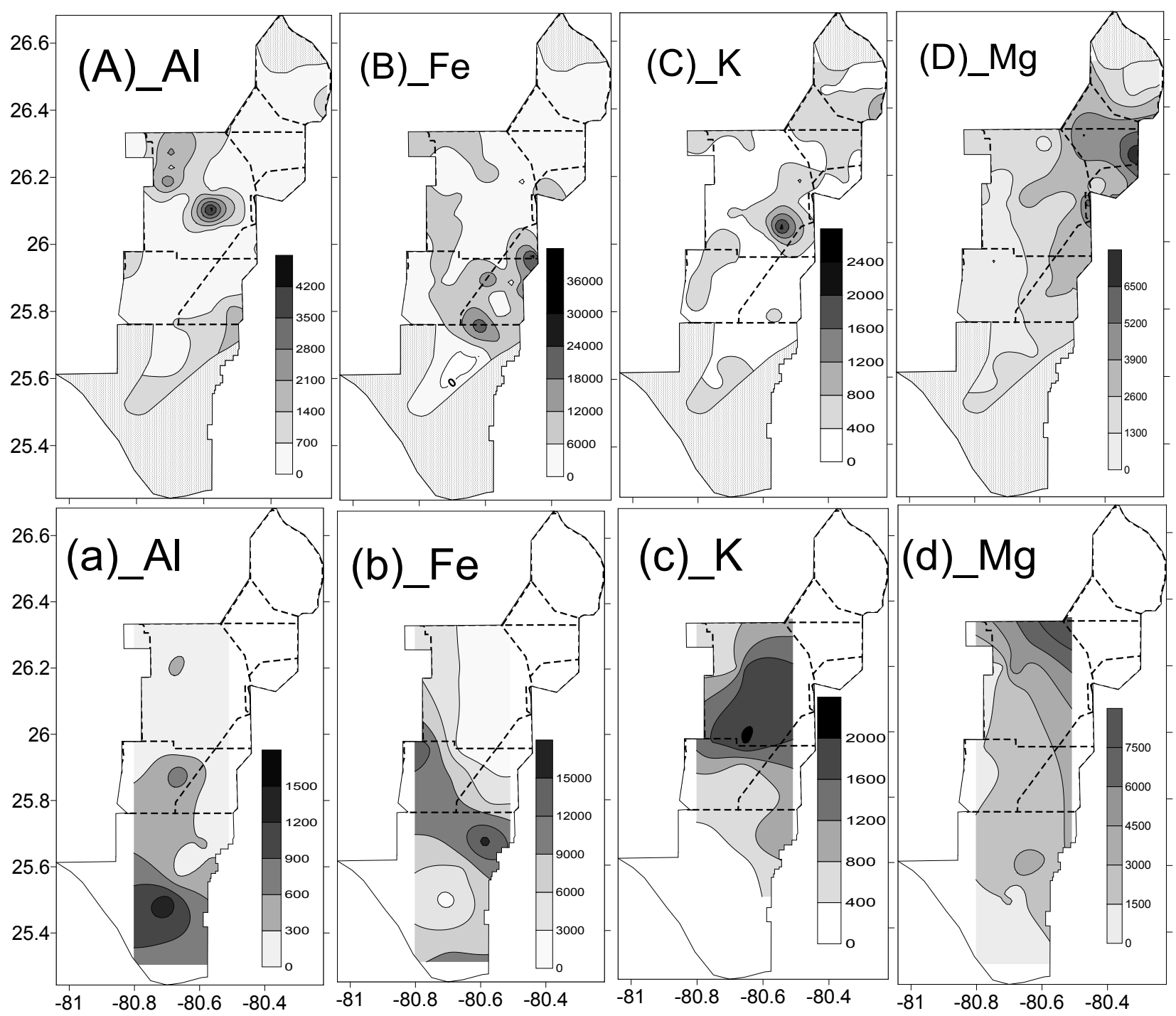

Figure 3-11 Spatial variation of essential metals in floc of Florida Everglades (A) Al, (B) Fe, (C) $\mathrm{K}$, and (D) Mg during the dry season (Top, labeled with capital letters) and wet season (bottom, labeled with lowercase letters). 


\subsubsection{Spatial distribution of metals in periphyton}

Spatial distribution patterns were plotted for benthic periphyton (Fig 3-12 through Fig 3-14), epiphytic periphyton (Fig 3-15 through 3-17) and floating periphyton (Fig 3-18through 3-20). Toxic and essential metals were categorized in the same way as soil and floc. Hot and cold spots were shown on each figure. 

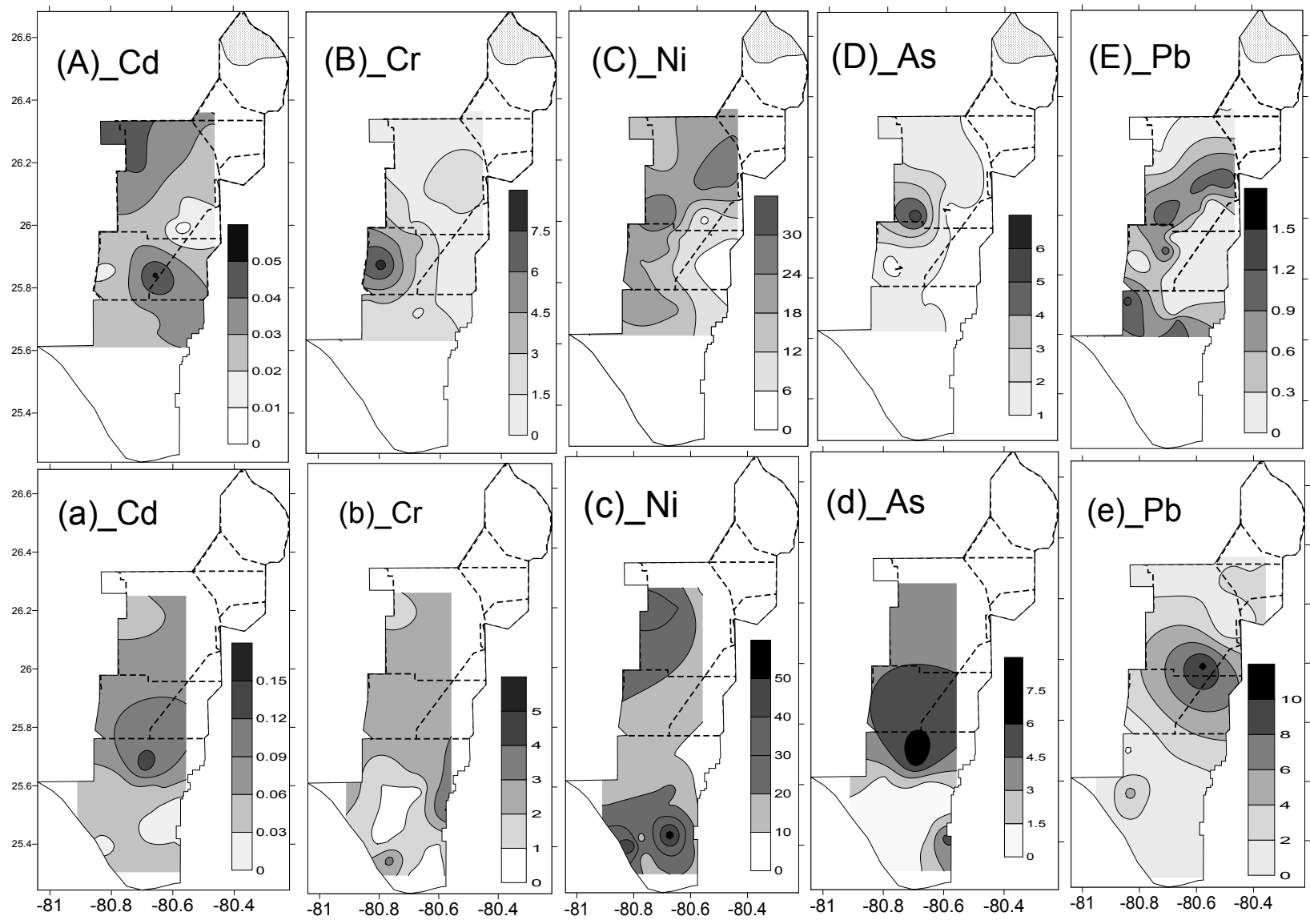

Figure 3-12 Spatial variation of toxic metals in Benthic Periphyton of Florida Everglades (A) $\mathrm{Cd}$, (B) $\mathrm{Cr}$, (C) $\mathrm{Ni}$, (D) As, and (E) $\mathrm{Pb}$ during the dry season (Top, labeled with capital letters) and wet season (bottom, labeled with lowercase letters). 


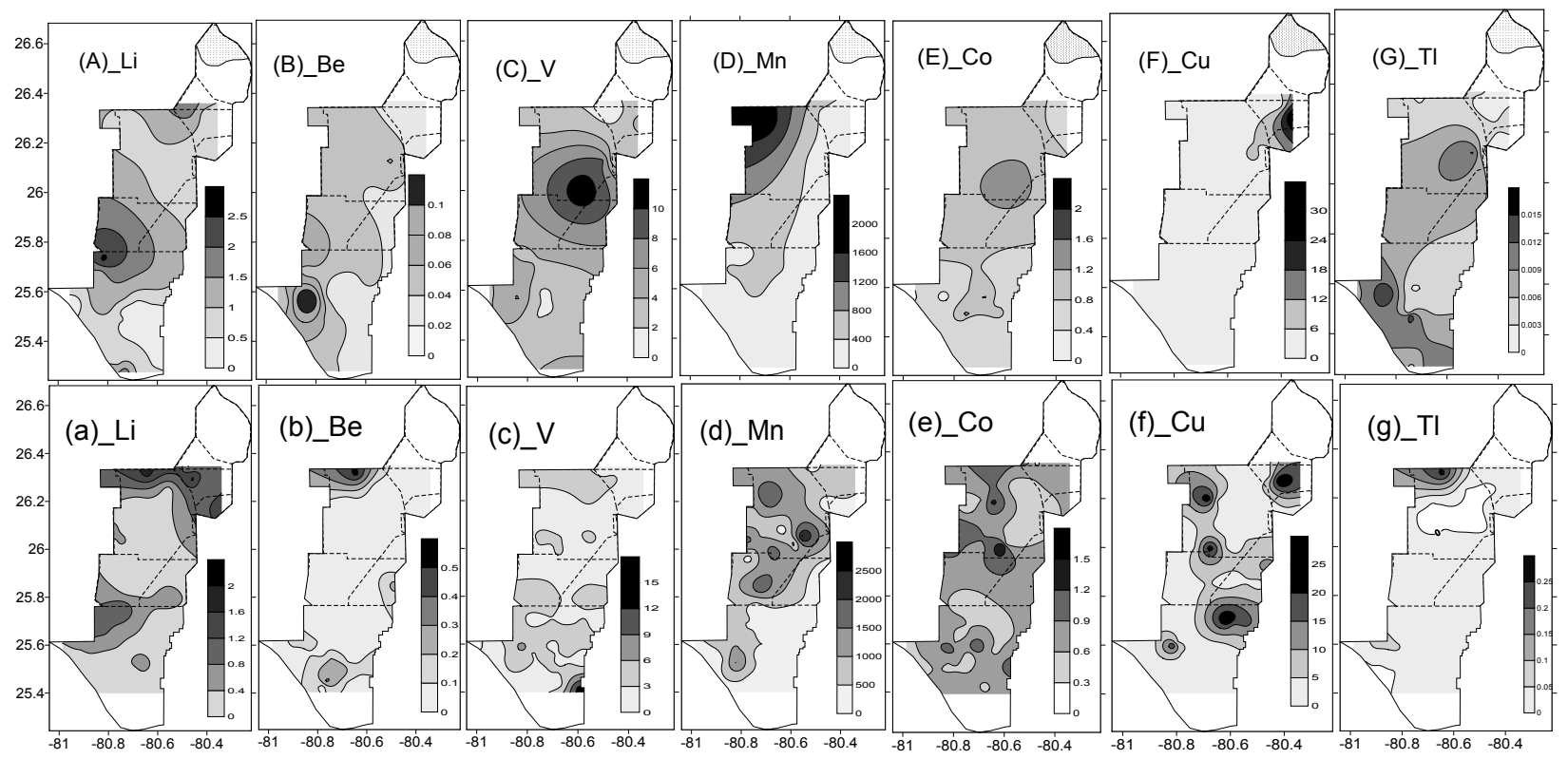

Figure 3-13 Spatial variation of essential metals in benthic periphyton of Florida Everglades (A) $\mathrm{Li},(\mathrm{B}) \mathrm{Be},(\mathrm{C}) \mathrm{V}$, (D) Mn, (E) Co, (F) Cu (G) Tl during the dry season (Top, labeled with capital letters) and wet season (bottom, labeled with lowercase letters). 

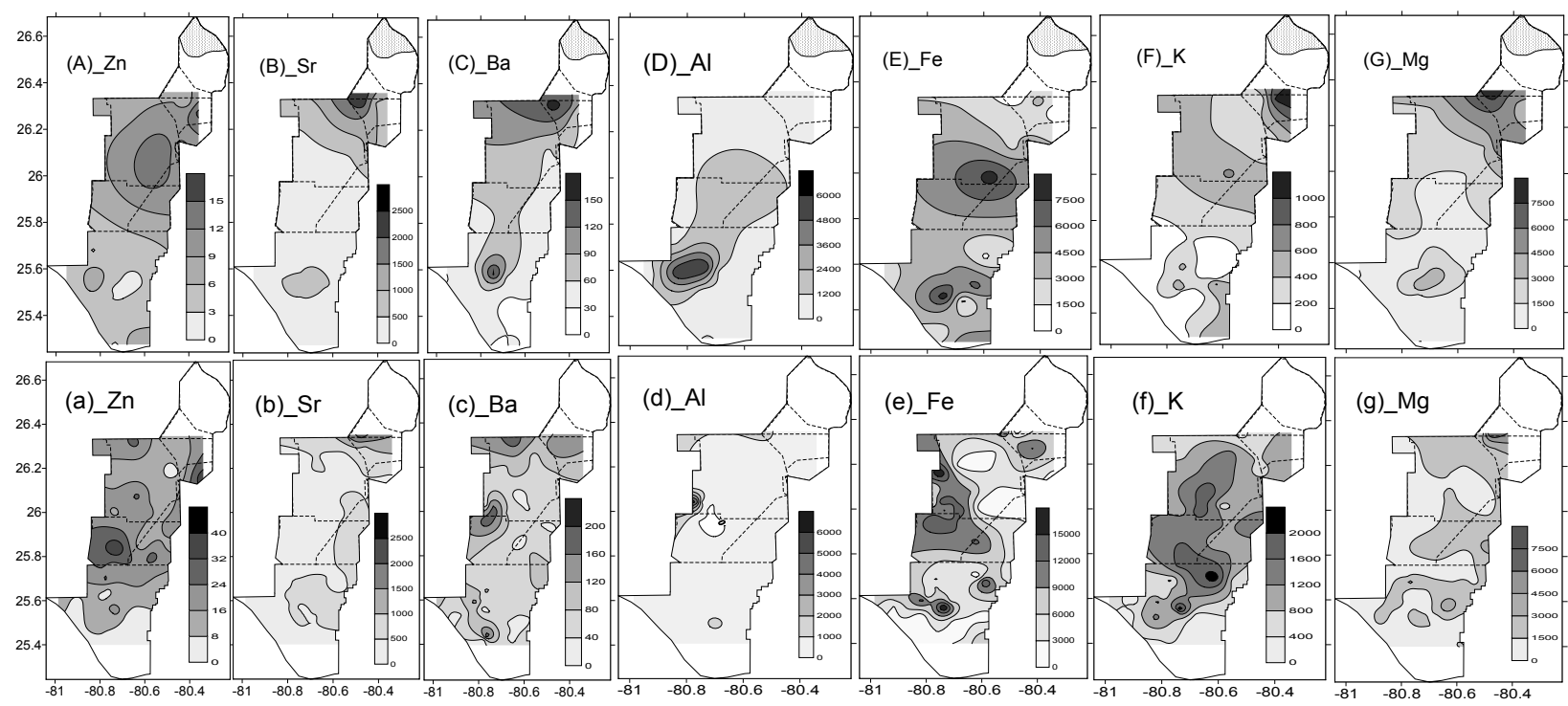

(d)_Al (e)_Fe
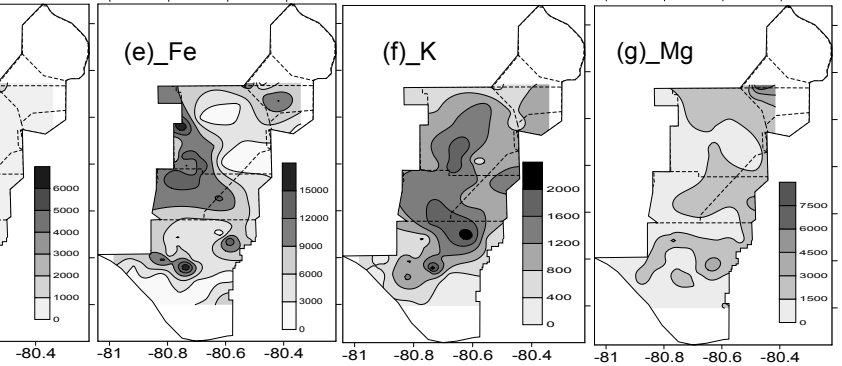

Figure 3-14 Spatial variation of essential metals in benthic periphyton of Florida Everglades (A) Zn, (B) Sr, (C) Ba, (D) Al, (E) Fe, (F) K, (G) Mg during the dry season (Top, labeled with capital letters) and wet season (bottom, labeled with lowercase letters). 

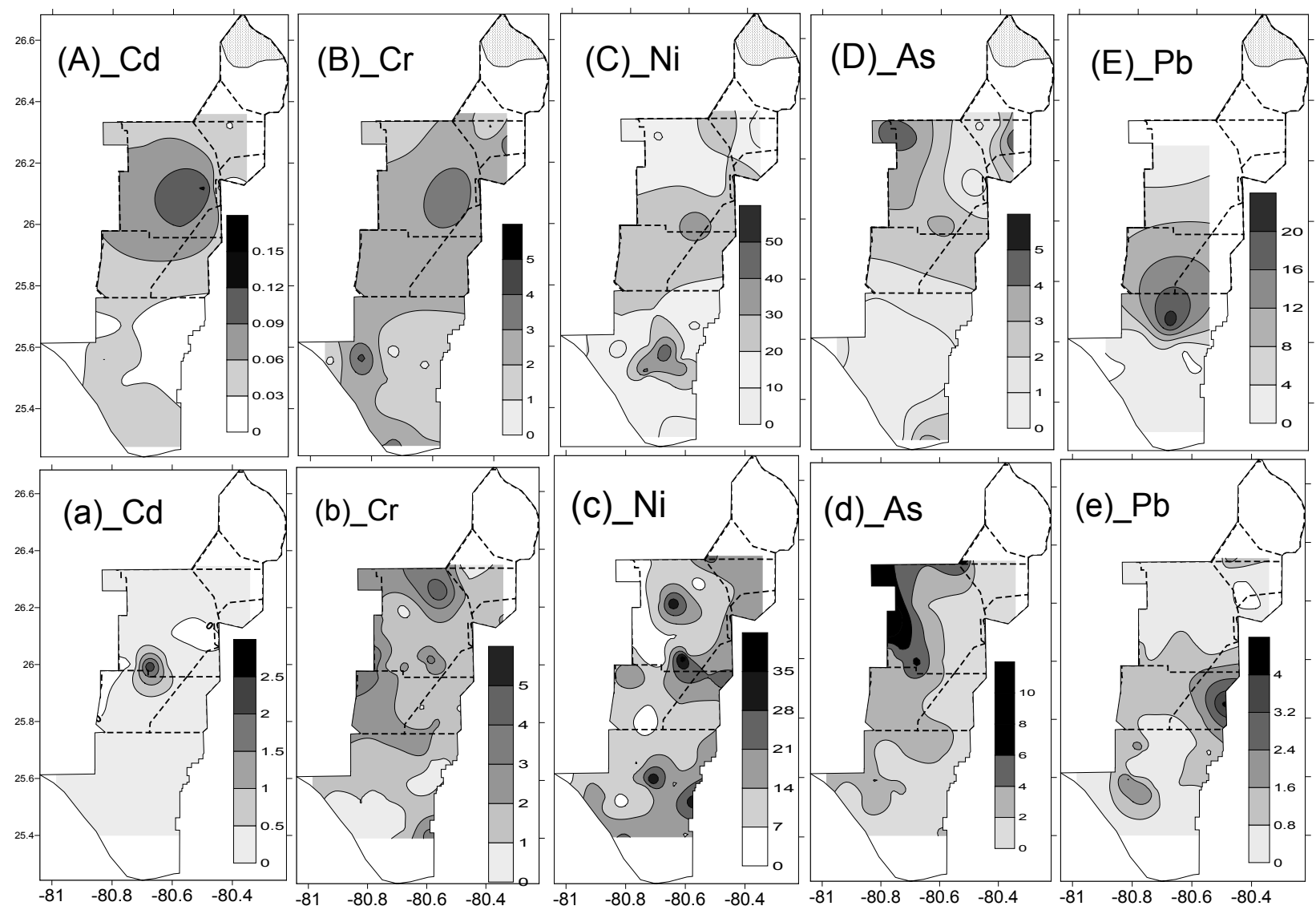

Figure 3-15 Spatial variation of toxic metals in Epiphytic periphyton of Florida Everglades (A) $\mathrm{Cd}$, (B) $\mathrm{Cr}$, (C) Ni, (D) As, and (E) Pb during the dry season (Top, labeled with capital letters) and wet season (bottom, labeled with lowercase letters). 

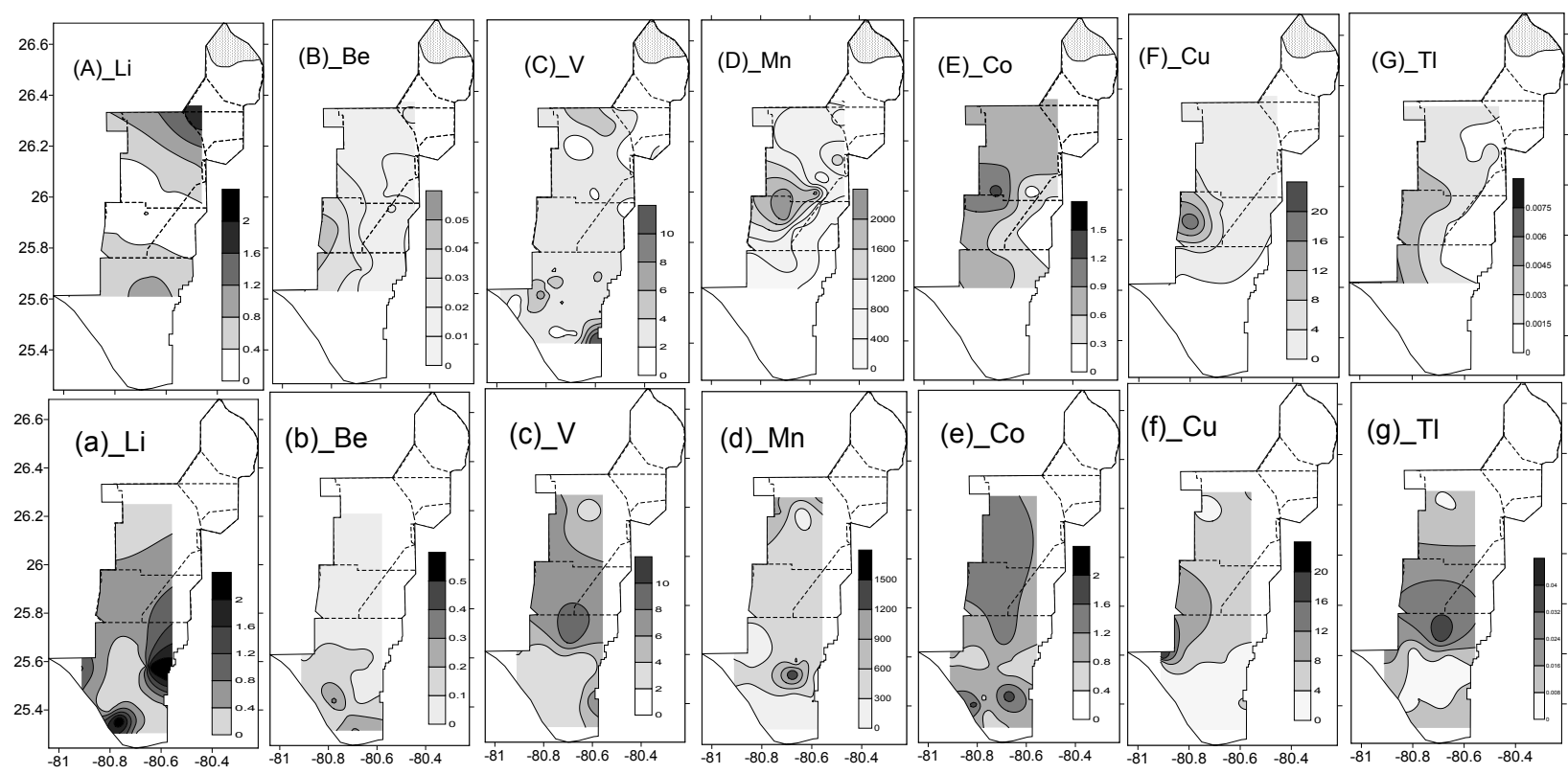

Figure 3-16 Spatial variation of essential metals in epiphytic periphyton of Florida Everglades (A) Li, (B) Be, (C) V, (D) Mn, (E) Co, (F) Cu (G) Tl during the dry season (Top, labeled with capital letters) and wet season (bottom, labeled with lowercase letters). 

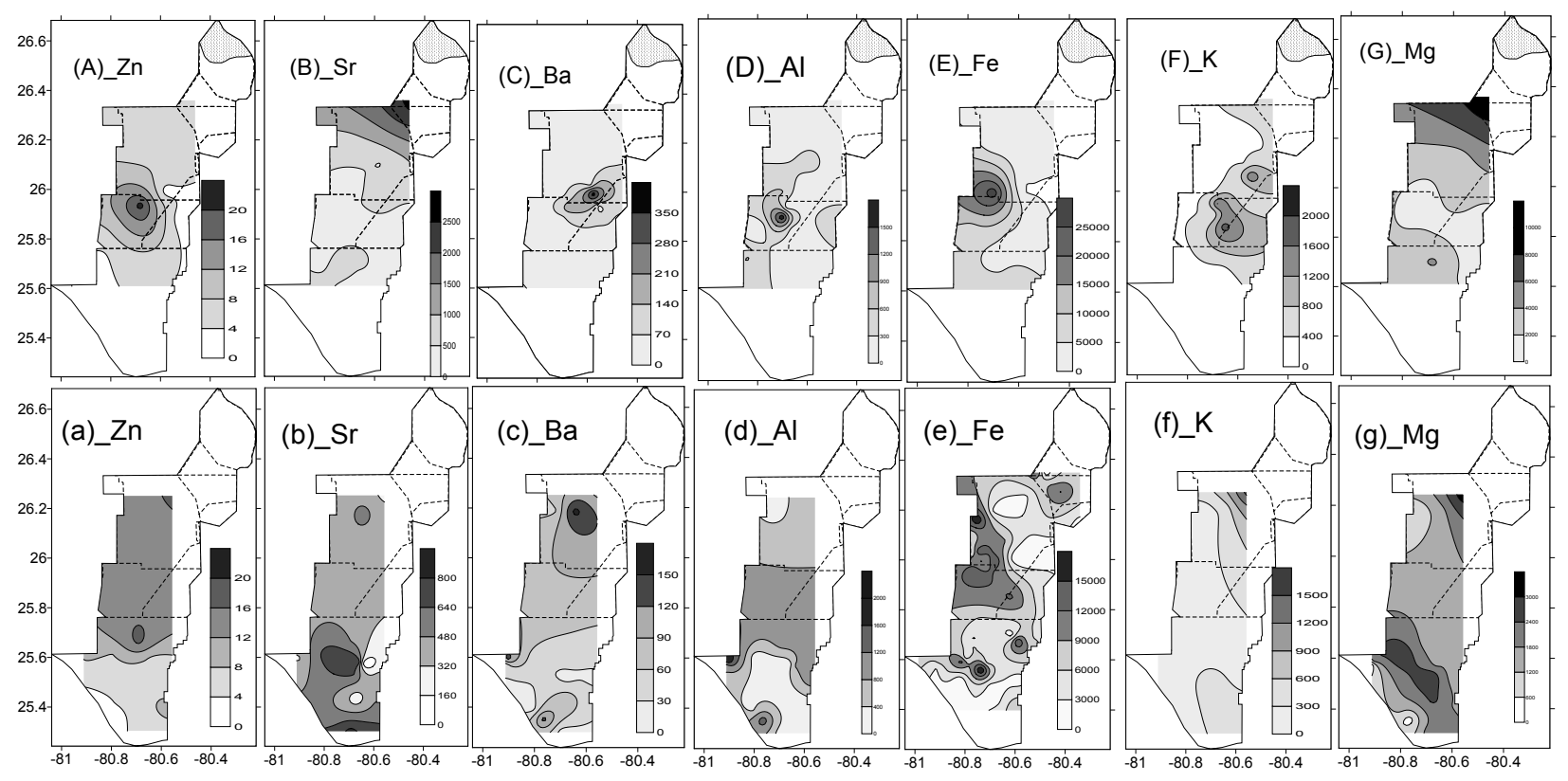

Figure 3-17 Spatial variation of essential metals in epiphytic periphyton of Florida Everglades (A) Zn, (B) Sr, (C) Ba, (D) Al, (E) Fe, (F) K, (G) Mg during the dry season (Top, labeled with capital letters) and wet season (bottom, labeled with lowercase letters). 


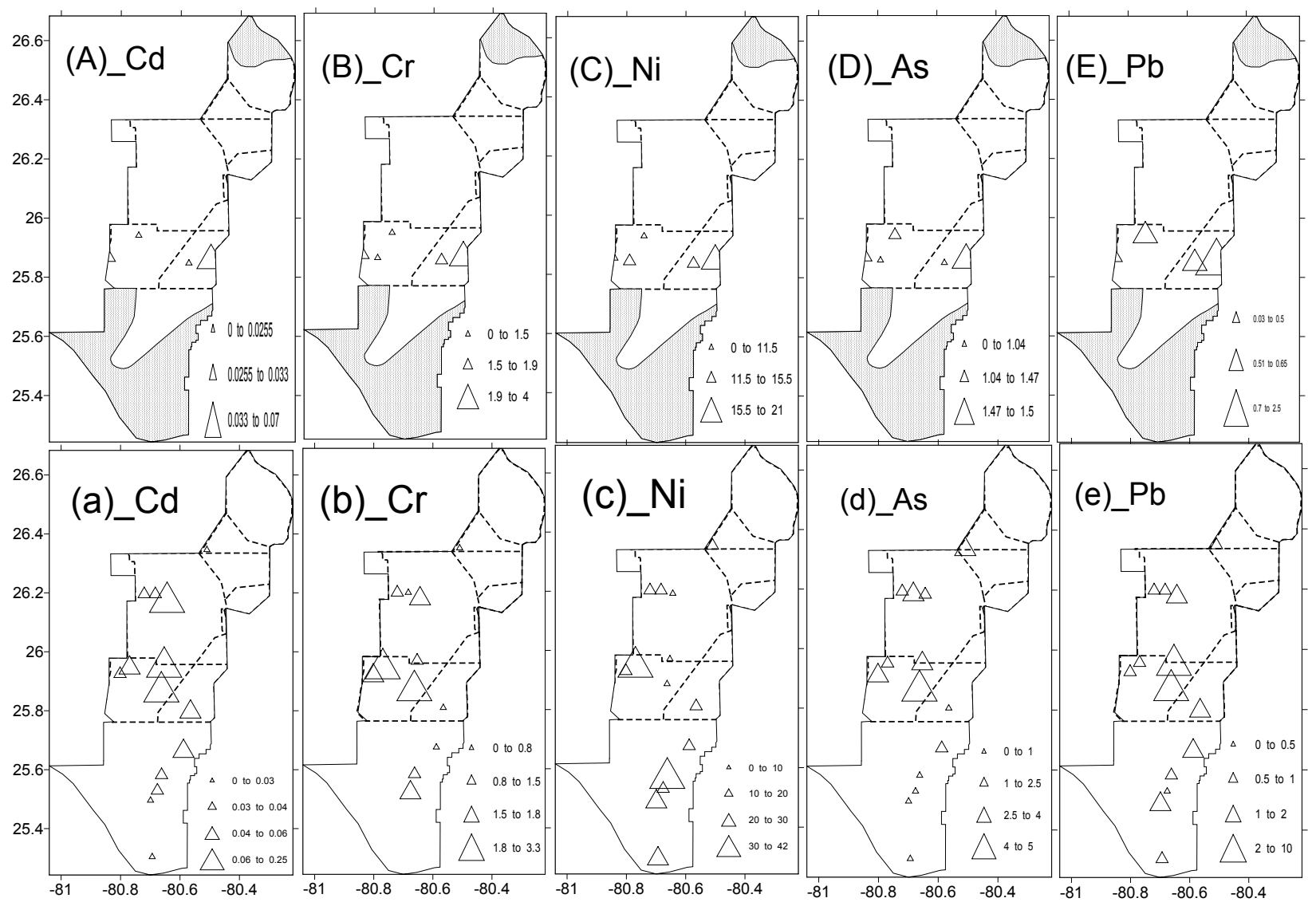

Figure 3-18 Spatial variation of toxic metals in floating periphyton of Florida Everglades (A)

$\mathrm{Cd}$, (B) Cr, (C) Ni, (D) As, and (E) Pb during the dry season (Top, labeled with capital letters) and wet season (bottom, labeled with lowercase letters). 

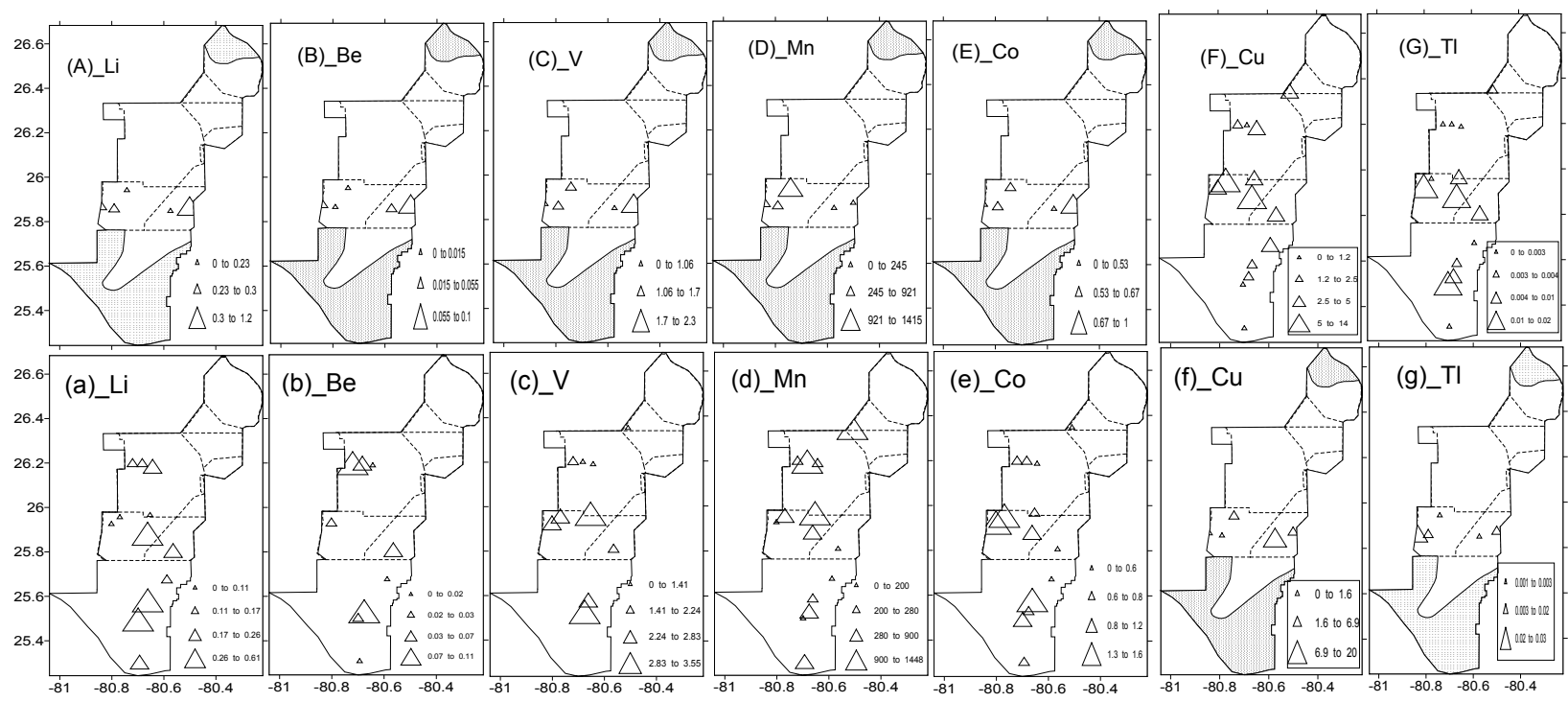

Figure 3-19 Spatial variation of essential metals in floating periphyton of Florida Everglades (A) Li, (B) Be, (C) V, (D) Mn, (E) Co, (F) Cu (G) Tl during the dry season (Top, labeled with capital letters) and wet season (bottom, labeled with lowercase letters). 

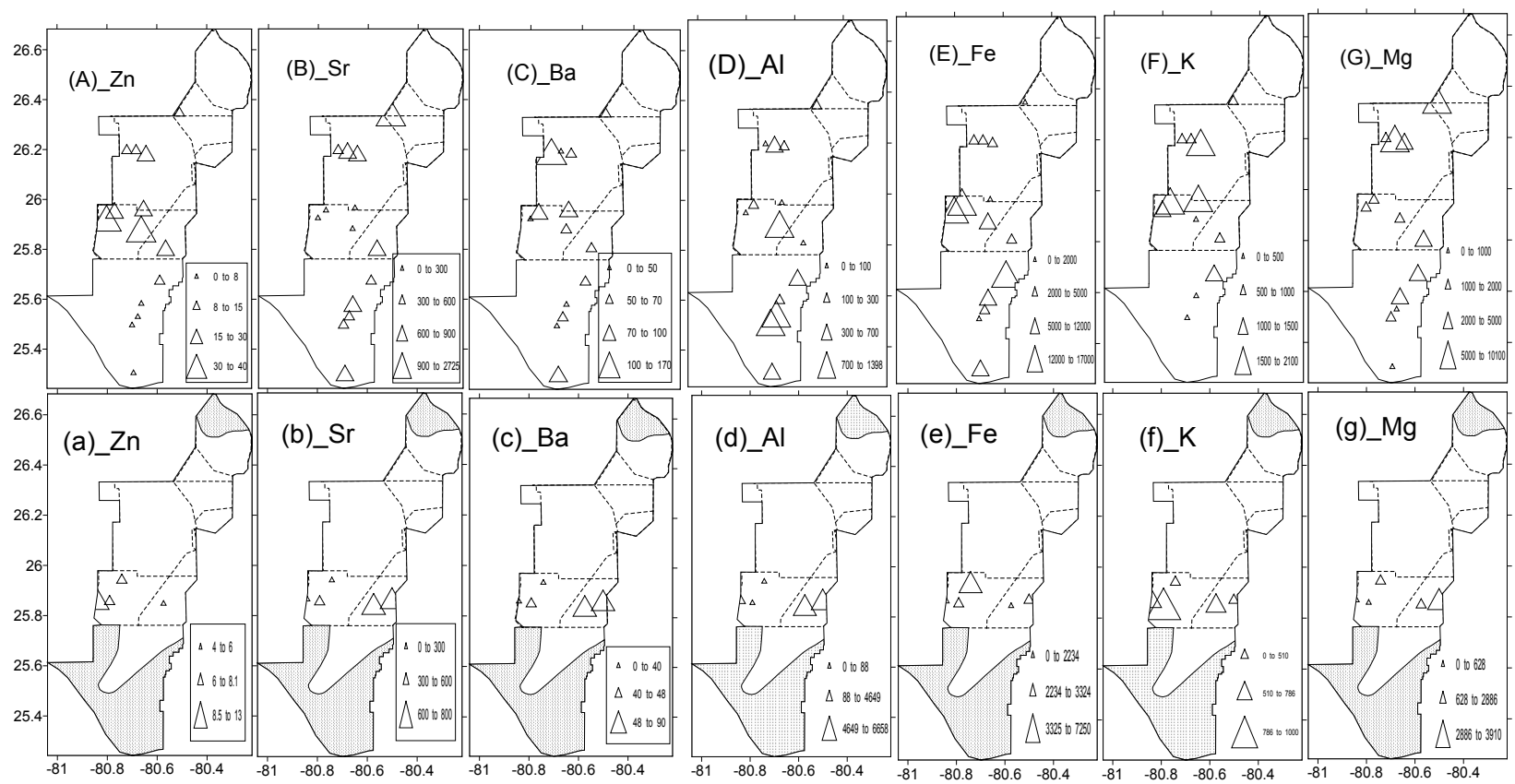

Figure 3-20 Spatial variation of essential metals in floating periphyton of Florida Everglades (A) Zn, (B) Sr, (C) Ba, (D) Al, (E) Fe, (F) K, (G) Mg during the dry season (Top, labeled with capital letters) and wet season (bottom, labeled with lowercase letters). 
In the dry season, $\mathrm{Ni}, \mathrm{Sr}$ and $\mathrm{Mg}$ exhibited clear spatial distribution pattern in which the concentration decreased from north to south for benthic periphyton (Fig 3-11 and 3-13). For epiphytic periphyton, concentrations of $\mathrm{Sr}$ and $\mathrm{Mg}$ decreased also from north to south. The distribution patterns were less clear for floating periphyton. The maximum concentrations were observed in several distinct locations in the dry season for all periphyton samples involved (Fig 3-12 though 3-14). In epiphytic periphyton, two locations, eastern and western area of WCA-3, contained hot spots for $\mathrm{Li}, \mathrm{V}, \mathrm{Sr}, \mathrm{Mg}, \mathrm{Cd}, \mathrm{Cr}$ and $\mathrm{Ni}$ as well as $\mathrm{Be}$, $\mathrm{Mn}, \mathrm{Co}, \mathrm{Cu}, \mathrm{Tl}, \mathrm{Zn}, \mathrm{Al}, \mathrm{Fe}$ and $\mathrm{Pb}$, respectively (Fig 3-15 through 3-17). In benthic periphyton, the eastern area ( $\mathrm{Li}, \mathrm{Cu}, \mathrm{Sr}, \mathrm{Ba}, \mathrm{K}, \mathrm{Mg}, \mathrm{Pb}, \mathrm{V}, \mathrm{Co}, \mathrm{Tl}, \mathrm{Zn}$ and $\mathrm{Fe}$ ) of WCA-3 contained most of hot spots (Fig 3-12 through 3-14). Other hot spots were location in areas including western ENP (Be, Tl, Al, Fe), western WCA-3 (Mn, Cd, As) (Fig 3-13 and 3-14). In floating periphyton, west ( $\mathrm{Li}, \mathrm{V}, \mathrm{Mn}, \mathrm{Co}, \mathrm{Cu}, \mathrm{Tl}, \mathrm{Zn}, \mathrm{AL}, \mathrm{Fe}$ and $\mathrm{K}$ ) and east ( $\mathrm{Sr}$ and $\mathrm{Mg}$ ) of WCA-3 were home to most hot spots (Fig 3-19 and 3-20). Two metals, Be and Ba, were mostly concentrated in the western area of WCA-3 (Fig 3-19 and 3-20).

In the wet season, no clear trends of spatial distribution patterns of metals were observed for periphyton. The distribution patterns for the wet season varied significantly when compared with the dry season (Fig 3-12 through 3-20). For epiphytic periphyton, maximum concentrations of metals $(\mathrm{Li}, \mathrm{Be}, \mathrm{Mn}, \mathrm{Co}, \mathrm{Al}, \mathrm{Fe}, \mathrm{Mg}$ ) were observed in the western corner of ENP (Fig 3-16 and 3-17). Other areas, such as mid ENP (V, Mn, Tl, Zn, Sr), west of ENP $(\mathrm{Cu})$ as well as east of WCA-3 (Ba and $\mathrm{K})$, were also home to hot spots (Fig 3-16 and 3-17). Toxic metals ( $\mathrm{Cr}$, Ni and As) had maximum concentrations near EAA (Fig 3-17). For benthic periphyton, the maximum concentrations were spotted in several 
places: west ( $\mathrm{Li}, \mathrm{Be}, \mathrm{Mn}, \mathrm{Co}, \mathrm{Tl}, \mathrm{Ba}$ and $\mathrm{Cd})$ and east $(\mathrm{Cu}, \mathrm{Sr}, \mathrm{Mg}$, Ni and $\mathrm{Pb})$ of $\mathrm{WCA}-3$

(Fig 3-13 and 3-14). For floating periphyton, hot spots were located in either east or west of WCA-3 under limited data (Fig 3-18 through 3-20).

\section{Discussion}

4.1 Factors influencing the spatial distribution of metals in the Florida Everglades 4.1.1 Effects of possible sources on metal distribution in the Everglades

Metals in the Everglades could originate from natural sources as well as anthropogenic sources. The Everglades is a 500,000 ha freshwater wetland mainly composed of sawgrass and open water slough (Craft and Richardson 1997). The soil matrix is composed of the most abundant metals in the earth's crust such as $\mathrm{Al}, \mathrm{Fe}, \mathrm{Mg}, \mathrm{K}$ and $\mathrm{Ca}$ (Schulze 1989). Peat soils, primarily found in the central Everglades, and marl soils, found in the shallow peripheral marshes, are two major soil types in the Everglades (Scheidt and Kalla 2007). Peat soils are formed as results of plant matter decay while marl soils are more calcitic in composition in association with calcitic algae mat (periphyton) (MePherson and Halley 1996), which contributes to the natural concentrations of $\mathrm{Cr}, \mathrm{Mn}, \mathrm{Co}, \mathrm{Ni}, \mathrm{Cu}, \mathrm{Zn}, \mathrm{Cd}$ and $\mathrm{Pb}$ (Nagajyoti et al. 2010). Under the soils, a large volume of carbonate sediments composed exclusively of limestone dolomite and anhydrite serve as sources to minerals such as $\mathrm{Fe}, \mathrm{Al}$ and Magnesium. Two major sloughs in the Everglades, Taylor and Shark Sloughs, carry surface water sheet flow from WCAs and EAA to Everglades National Park. They might serve as sinks for elements from erosion of soils and weathering of the underlain sediment rocks (Gough et al. 2000). 
Anthropogenic sources could include farming activities in the EAA area, atmospheric deposition, road traffic, tourism (airboat), and the regional airport. The distribution of metals could partially be explained by the impact of these potential sources. Everglades Agricultural Area is about 7,000 acres (account for $27 \%$ of total historic Everglades) with major productions in sugarcanes (Light 2010). A large amount of fertilizer was used to enhance the growth of sugarcanes, snap beans, cabbage, and other crops in EAA area (Förstner and Wittmann 1981; MePherson and Halley 1996). Nitrogen and phosphate containing fertilizers are widely used in the agricultural production at the rate of 7 tons $/ \mathrm{mi}^{2}$ for nitrogen and 3 tons $/ \mathrm{mi}^{2}$ for phosphate. Average concentrations of toxic metals $(\mathrm{Pb}, \mathrm{As}, \mathrm{Cd}, \mathrm{Cr}$ and $\mathrm{Ni})$ presented in the phosphate (P) fertilizers in the U.S. are shown in Table 4.1. Since currently there are no data on the background concentrations of toxic metals in the Everglades area, toxic metals in the $\mathrm{P}$ fertilizers were compared with sediment quality guidelines (SQGs) designed for freshwater sediment assessment. All toxic metals from fertilizers exceeded limits of "no effect" category, and some metals surpassed limits set for "probable effect" category. Several major canals including Miami canal, North new river canal and Hillsboro canal, along with large capacity pump stations, were constructed in an effort to prevent flooding in EAA by diverting water into WCAs and LNWR (Figure 4-3). Toxic metals from fertilizers might be carried by the canals and enter WCAs and LNWR. Because of the absence of background concentrations of toxic metals in the Everglades, The concentrations of $\mathrm{As}, \mathrm{Pb}, \mathrm{Cu}$ and $\mathrm{Zn}$ from the current study were compared to Sediment Quality Guideline values. All metals compared exceeded no-effect category of SQGs. The high concentrations found in WCAs and LNWR varied for $\mathrm{Cu}(52-65 \mathrm{mg} / \mathrm{Kg})$, As $(7.5-10 \mathrm{mg} / \mathrm{Kg}), \mathrm{Pb}(125-250$ $\mathrm{mg} / \mathrm{Kg}$ ) and $\mathrm{Zn}(20-25 \mathrm{mg} / \mathrm{Kg}$ ) for the dry season (Fig 4-1). The detected concentrations 
were well above FL SQGs in the no effect category which might be attributed to agricultural applications (e.g. fertilizers) in the Everglades Agricultural Area.

Table 4-1 Comparison of toxic metals in $\mathrm{P}$ fertilizers and in sediment quality guidelines (SQGs) LEL=Lowest Effect Levels; TEL= threshold effect levels; $S E L=$ severe effect level; PEL=probable effect levels

\begin{tabular}{l|l|l|l|l|l}
\hline SQGs & $\begin{array}{l}\mathrm{As} \\
(\mathrm{mg} / \mathrm{Kg})\end{array}$ & $\begin{array}{l}\mathrm{Cd} \\
(\mathrm{mg} / \mathrm{kg})\end{array}$ & $\begin{array}{l}\mathrm{Cr} \\
(\mathrm{mg} / \mathrm{kg})\end{array}$ & $\begin{array}{l}\mathrm{Ni} \\
(\mathrm{mg} / \mathrm{kg})\end{array}$ & $\begin{array}{l}\mathrm{Pb} \\
(\mathrm{mg} / \mathrm{kg})\end{array}$ \\
\hline $\begin{array}{l}\text { No effects } \\
\text { LEL(Florida) }\end{array}$ & 6 & 0.6 & 26 & 16 & 31 \\
TEL(Florida) & 5.9 & 0.6 & 37 & 18 & 35 \\
$\begin{array}{l}\text { Probable } \\
\text { effects }\end{array}$ & & & & \\
$\begin{array}{l}\text { SEL(Florida) } \\
\text { PEL(Florida) }\end{array}$ & 33 & 10 & 110 & 75 & 250 \\
P fertilizers & 12 & 90 & 197 & 36 & 91.3 \\
\hline
\end{tabular}



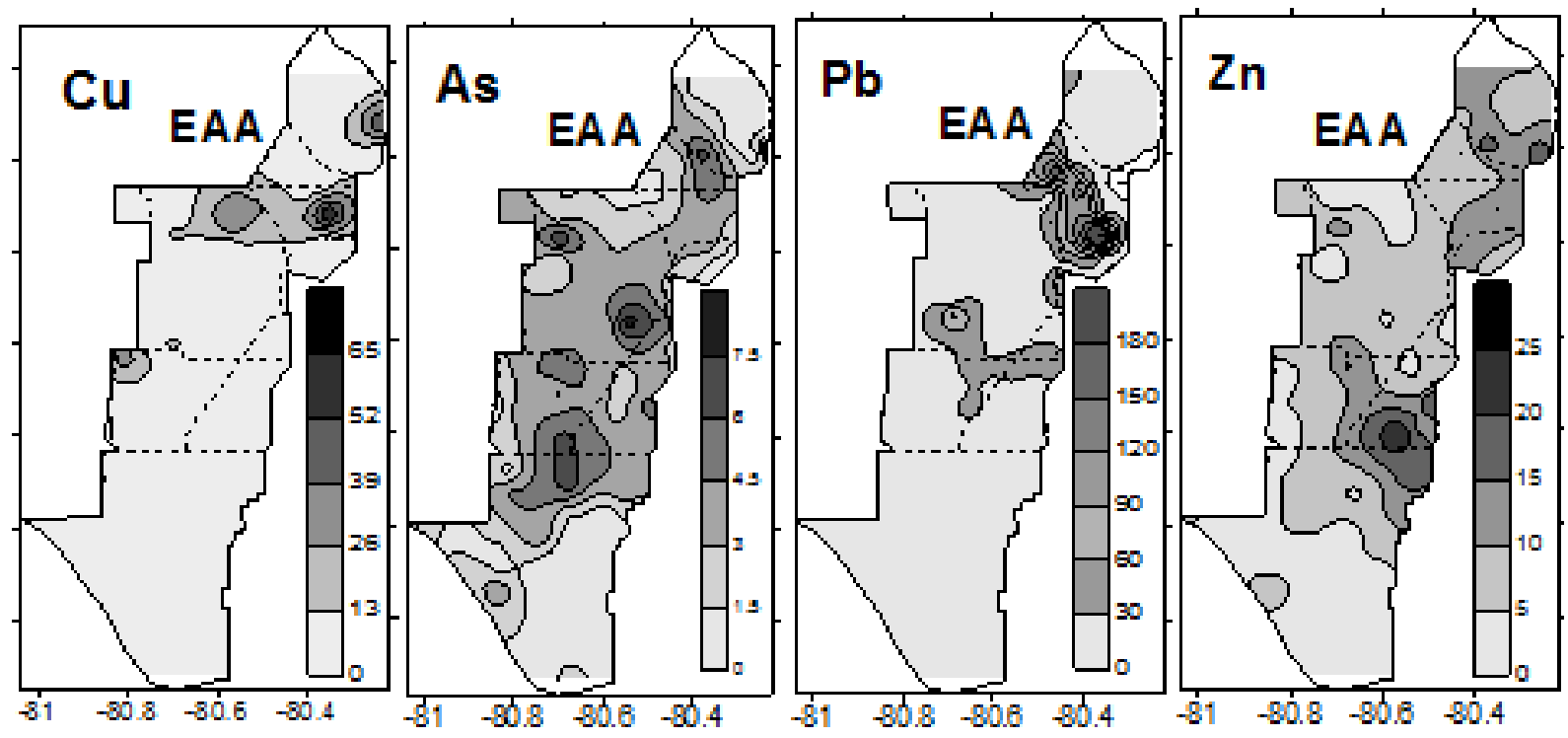

Figure 4-1 Metals with elevated concentrations $(\mathrm{mg} / \mathrm{Kg})$ for $\mathrm{Cu}, \mathrm{As}, \mathrm{Pb}$ and $\mathrm{Zn}$ in soils from the dry season that are possibly affected by fertilizers applied in EAA

Areas in the immediate vicinity of major roads could be under stress of metals that result from the elevated heavy metal concentrations from roadway emissions generated mainly from vehicle component and equipment (brakes, tires, parts wear and lubricant oil in engine) (Pagotto et al. 2001; Viard et al. 2004; Apeagyei et al. 2011). The deposited metals from roads might be accumulated on the road surface and eventually be transported via resuspension or carried by runoff to the nearby soil (Turer et al. 2001). Schauer et al. (2006) studied metals in crushed brake pads and housing dust and confirmed $\mathrm{Fe}, \mathrm{Cu}$ and $\mathrm{Ba}$ to be the most abundant elements. The tire analyses from the same study found that $\mathrm{Zn}$ concentrations were about 15 times higher than concentrations of $\mathrm{Zn}$ in brakes. Other parts of the motor vehicles such as rotor (made from cast iron) or drum against which the brake pad presses can contribute to the elevated concentrations of iron. In addition, Ba was found in a large amount in brake wear emissions. Zinc and Ba components are employed extensively in lubricant oils 
for diesel and other combustion engines (deMiguel et al. 1997). Exhaustive studies have shown correlations between metal concentrations and road side soils (Turer et al. 2001; Apeagyei et al. 2011; Mejia et al. 2011; Mikalajune and Jakucionyte 2011; Zafra et al. 2011). Lead and $\mathrm{Zn}$ originated from vehicular traffic were detected at high concentrations 26, 988 and $6,156 \mathrm{ug} / \mathrm{g}$, which became the major components of metal pollutions to Sydney estuary catchment soils (Birch et al. 2011). Turer et al. (2001) determined that Pb sampled in the roadside soil could mainly originate from vehicle exhaust when leaded fuel was still used in Cincinnati, Ohio. Concentrations of $\mathrm{Zn}, \mathrm{Cu}, \mathrm{K}, \mathrm{Ti}, \mathrm{Sr}$ and $\mathrm{Ca}$ found in brake pads were found to correlate with elevated concentrations in road dust (Apeagyei et al. 2011). Previous studies indicated that road dusts associated with high traffic road could contain high concentrations of $\mathrm{Cr}, \mathrm{Fe}, \mathrm{Cu}, \mathrm{Pb}$, and $\mathrm{Zn}$, in both urban and rural area (Pagotto et al. 2001; Viard et al. 2004; Apeagyei et al. 2011). Similar results of elevated metal concentrations were found in my study: several of toxic metals including $\mathrm{Cr}$, As and Zn (Figure 4-2) showed several "hot spots" in soil samples near two major roadways, US I-75 and US Route 41. US Route 41 is a major road that extends from Miami in the east of South Florida to Naples in the west of South Florida, The highest Cr level varied between 48 to $60 \mathrm{mg} / \mathrm{kg}$ was found in the vicinity of I-75, a major interstate highway traveled from south of Florida to Michigan. Elevated concentration of $\mathrm{Zn}(20 \mathrm{mg} / \mathrm{Kg})$ was also found near both roads, implying that road dusts might play an important role in the distributions of both $\mathrm{Cr}$ and $\mathrm{Zn}$ in the Everglades. 


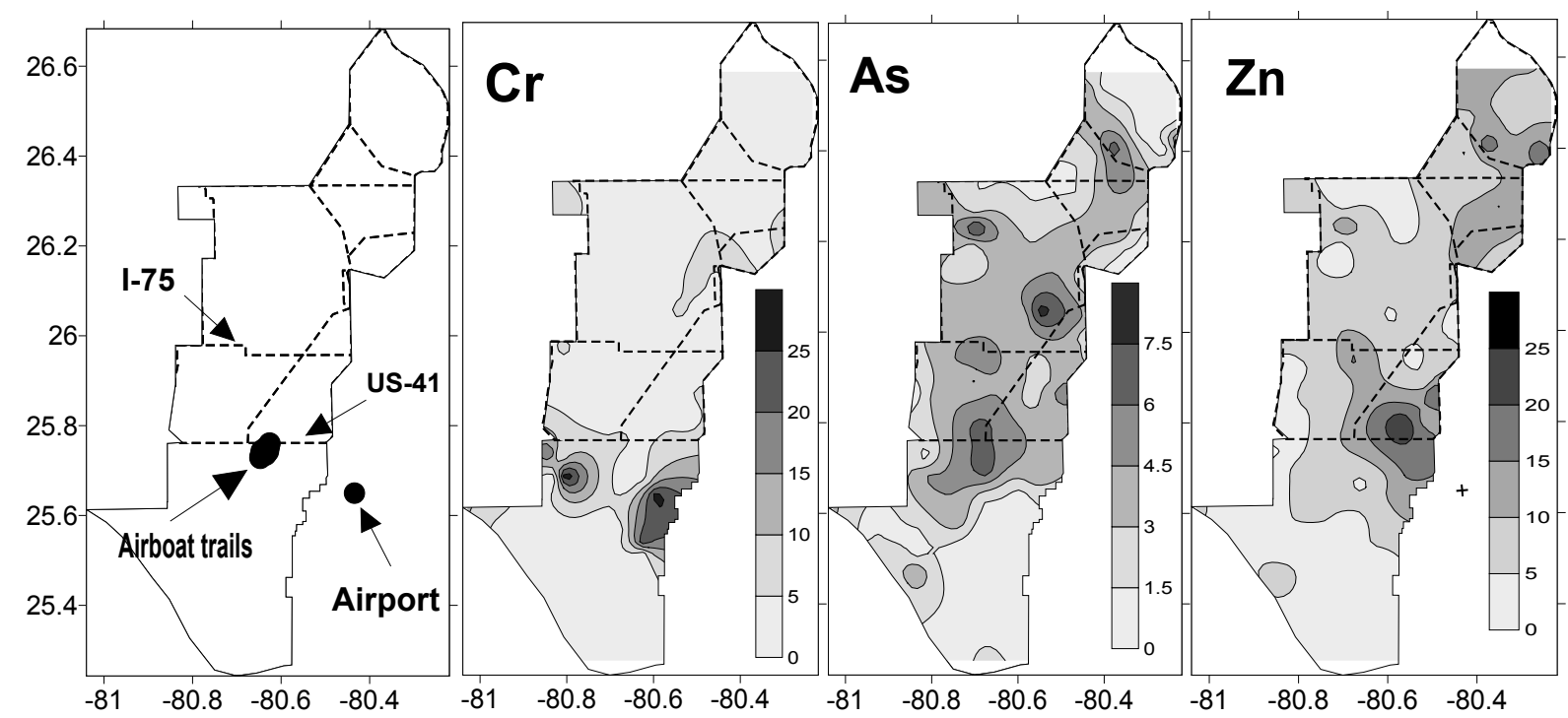

Figure 4-2 Distribution of metals (Cr, As and $\mathrm{Zn})$ in soil $(\mathrm{mg} / \mathrm{kg})$ from the dry season possibly influenced by road traffic, airboat trails and airport

Airboats have been used extensively in the marshes of the Everglades. Numbers of airboats have been increased since the 80 s of last century (Johnston 1984). Several studies have done on adverse impact of airboat activities on the hydrology (Weeks 1989), soils (Yamataki 1994) and vegetation (KcKee 1993). Alongside of U.S. Route 41, multiple businesses offer airboat tours with routes regulated under the state laws (FWC 2012). Routes taken by commercial airboats in the Everglades were indicated in Figure 4-2. Although few studies were conducted on the metal pollutions in the Everglades area in association with airboat activities, use of airboats would probably cause alterations of flow pattern, soil displacement (oxidation), and change in plant composition (Wright 2000; Rehage and Trexler 2006). The oxidation in the soil and change in vegetation communities might negatively impact the cycling of metals in different matrices (soil, floc and periphyton). Boat paint and parts involved in airboat operation and emission from gas burning could also 
contribute to the elevated levels of As and Zinc (Figure 4-2). Arsenic (>7.5 mg/kg) and Zn $(>20 \mathrm{mg} / \mathrm{kg}$ ) showed elevated concentrations in the immediate surrounding areas of the regulated airboat trails, suggesting potential correlations with airboat activities.

Aircraft emissions containing toxic metals can potentially harm both the environment and animal health (Lee et al. 2010). The main emitted species are generated from combustion of kerosene with ambient air in the engine combustion chamber. Some emitted species may contain metals $(\mathrm{Cu}$ and $\mathrm{Zn})$ from fuel system (Lee et al. 2010), and from erosion of metal parts (Demirdjian et al. 2007). Chromium plating has been used in gas turbine engine maintenance operations to repair worn Darts and replace worn or damaged Cr used (Schell and Rechsteiner 2000). High emissions of Cr (VI) were found from aircraft engines (Agrawal et al. 2008). The elevated concentrations of $\mathrm{Cr}(>25 \mathrm{mg} / \mathrm{Kg})$ and $\mathrm{Zn}(>25 \mathrm{mg} / \mathrm{Kg})$ were detected near Kendall-Tamiami Executive Airport (KTMB) located in the vicinity of northwestern region of Everglades National Park (Fig 4-2). As one of the busiest general aviation airports in Florida (KTMB 2012), the aviation activities from KTMB might contribute to the high concentrations of $\mathrm{Cr}$ and $\mathrm{Zn}$ in the nearby Everglades area.

The eastern panhandle of the ENP, along with Shark River slough, and Taylor River slough regularly receive water from canal constructed in the 70s as part of Central and South Florida (C\&SF) project (Sklar et al. 1999). Shark River slough receives water from canal (L67A) that was originated in Everglades Agricultural Area. Furthermore, canal S-332 was constructed to deliver water from north (EAA) into Taylor river slough (Figure 4-3). Manganese, $\mathrm{K}$ and $\mathrm{Sr}$ in soil all had high concentrations in the surrounding areas of EAA in the north and in the south of Everglades National Park (Figs 3.4 through 3.6). The elevated 
concentrations of $\mathrm{Mn}, \mathrm{K}$ and $\mathrm{Sr}$ in the surrounding areas of EAA could be attributed to the terrestrial input and runoff from EAA, as water move from north of Everglades to the south carrying input influenced by agricultural and rural development area (EAA). The arid regions of North Africa are inordinate source of soil dust. Large amounts of soil containing toxic metals are taken during the dust storm and transported to other continents on the prevailing winds (Perry et al. 1997). Atmospheric deposit of African dust may contribute to the elevated concentrations of $\mathrm{Pb}, \mathrm{As}, \mathrm{Cu}$ and $\mathrm{Fe}$ in the Florida Bay area during the low tide flux (Thornberry 2008).

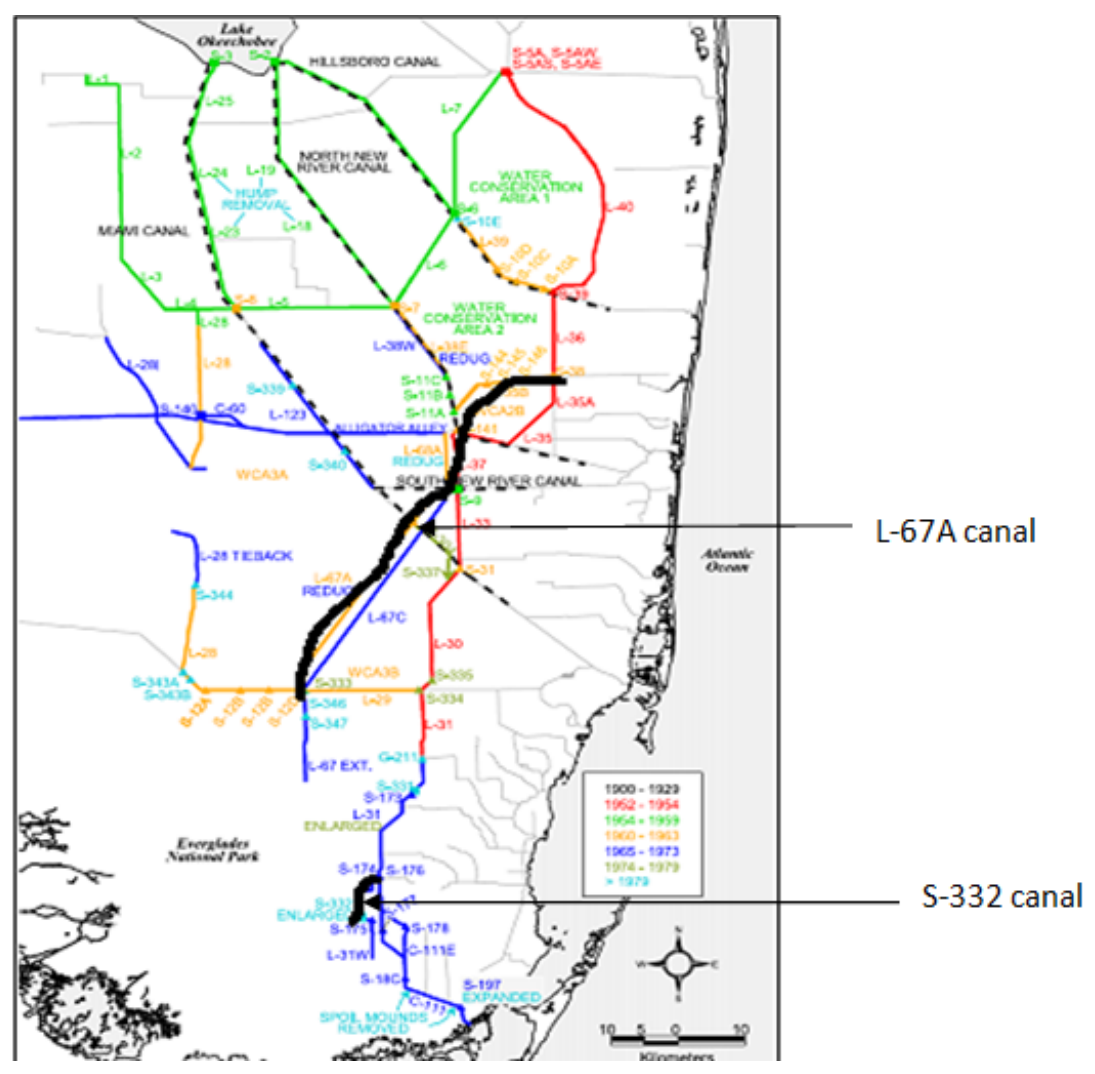

Figure 4-3 Diagram showing canals and levees in the Everglades (Light and Dineer 1994). 


\subsubsection{Effects of environmental parameters and metal-metal interactions on the}

distribution of metals in the Florida Everglades

In addition to the above-mentioned sources, some important environmental factors, such as soil natural organic matter $(\mathrm{NOM})$, soil $\mathrm{pH}$, oxidation-reduction potential (redox) and dissolved organic matter (DOM) could potentially impact on the distributions of metals. NOM is mainly composed of carbon, oxygen and small amount of N and P (EPA 2007). It is formed by all detrital organic matter in a natural system, making it an important component of the majority of freshwater environment (Warren and Haack 2001). Aquatic NOM could be categorized based on size: DOM and particular organic matter (POM). DOM is defined as the organic matter that passes through a $0.45 \mu \mathrm{m}$ pore filter while POM does not. Organic matter is known to have strong binding ability to retain inorganic soil contaminants (metals) (Hesterberg 1998; Perkins et al. 2000). In the Everglades, the highest organic matter content was found in LNWR with median of 94\%, followed by WCA-3 and WCA-2 with $75 \%$ organic matter. The peat soils in the north are generally rich in organic while the marl soils in the south are minerals (Scheidt and Kalla 2007). Humic substances are major parts of NOM in soil and water. (Frimmel 1998). Peat soils are also highly enriched in humic substances (Hajje and Jaffe 2006). Humic substances bind with metals either through forming soluble organic complexes to retain metals in soil or forming insoluble complexes resulting in reduction in bioavailability of metals (Logan et al. 1997). Mineral surface reaction with metals occurs mainly through sorption process (Brown et al. 1999). Variables controlling rate of sorption depend on several factors including $\mathrm{pH}$, mineral surface charge, and type of sorption complex formed, among others (Brown et al. 1999). As pH increases, metals (such as $\mathrm{Pb}$ ) existing as cations over a wide $\mathrm{pH}$ range have higher affinities for a mineral surface, 
while metals (such as As) behaving as anions have lower affinities. In contrast, NOM is always negatively charged under normal environmental conditions and show high affinity for cationic metal species (Warren and Haack 2001).

Dissolved organic matter has a strong influence on the fate of dissolved metal in metal-organic complexes (Sauve et al. 2000). DOM is known to strongly bind toxic metals such as $\mathrm{Cu}, \mathrm{Pb}, \mathrm{Cd}, \mathrm{Zn}$ and $\mathrm{Ni}$ (Weng et al. 2002). In the aquatic environment, humic substance makes up majority of DOM (Weng et al. 2002). Humic-metal complexes can be categorized into two groups: outer sphere complexes, which are favored by alkali and alkaline (e.g., $\mathrm{Be}, \mathrm{Mg}, \mathrm{Ca}, \mathrm{Sr}, \mathrm{Ba}$ ) earth metals that metal is held more loosely than inner sphere complexes, which is preferred by transition elements (e.g., $\mathrm{Cu}, \mathrm{Cd}, \mathrm{Zn}$ and $\mathrm{Pb}$ ) based on formation of a covalent bond between ligands and metal ions (Logan et al. 1997). Metal cations (e.g., $\mathrm{Mg}^{2+}, \mathrm{Al}^{3+}$ ) that are compact and not very polarizable prefer reactions with ligands that are also less polarizable (e.g., O-containing ligands). These are known as hard acids and bases. Large and more polarizable metals (e.g., $\mathrm{Cd}^{2+}, \mathrm{Cu}^{2+}$ ) are likely to react with more polarizble ligands (e.g., S-, P- and N-containing ligands. Table 4-2 illustrated some examples of both hard and soft acids as well as bases. Significant correlation were observed between DOC and metals in soils $(\mathrm{Ni}, \mathrm{Cu}, \mathrm{As}, \mathrm{K}$ and $\mathrm{Mg})($ Table 4.3) $(\mathrm{p}<0.01)$. The close correlation between $\mathrm{DOM}$ and $\mathrm{Pb}$ confirmed the statement that organic matter content plays an essential role in the $\mathrm{Pb}$ sorption by soil (Lee et al. 1998). Other study showed that $\mathrm{Pb}$ was preferably associated with soil organic fraction, as verified by the current study (Dragovic et al. 2008). Ash free weight represents the content of organic matter in soils. The significant correlations found between ash free weight $(\mathrm{OM}$ in soil) and transitional metals $(\mathrm{Cu}, \mathrm{As}, \mathrm{Pb}$ 
and $\mathrm{Zn}$ ) were probably resulted from formation of inner sphere complexes of those two groups (Fig. 4-4). Most metals were significantly correlated with ash free weight of the soil (except for $\mathrm{V}, \mathrm{Cr}, \mathrm{Fe}, \mathrm{K}$ and $\mathrm{Mg}$ ), indicating the important role that $\mathrm{NOM}$ play in regulating metal distribution.

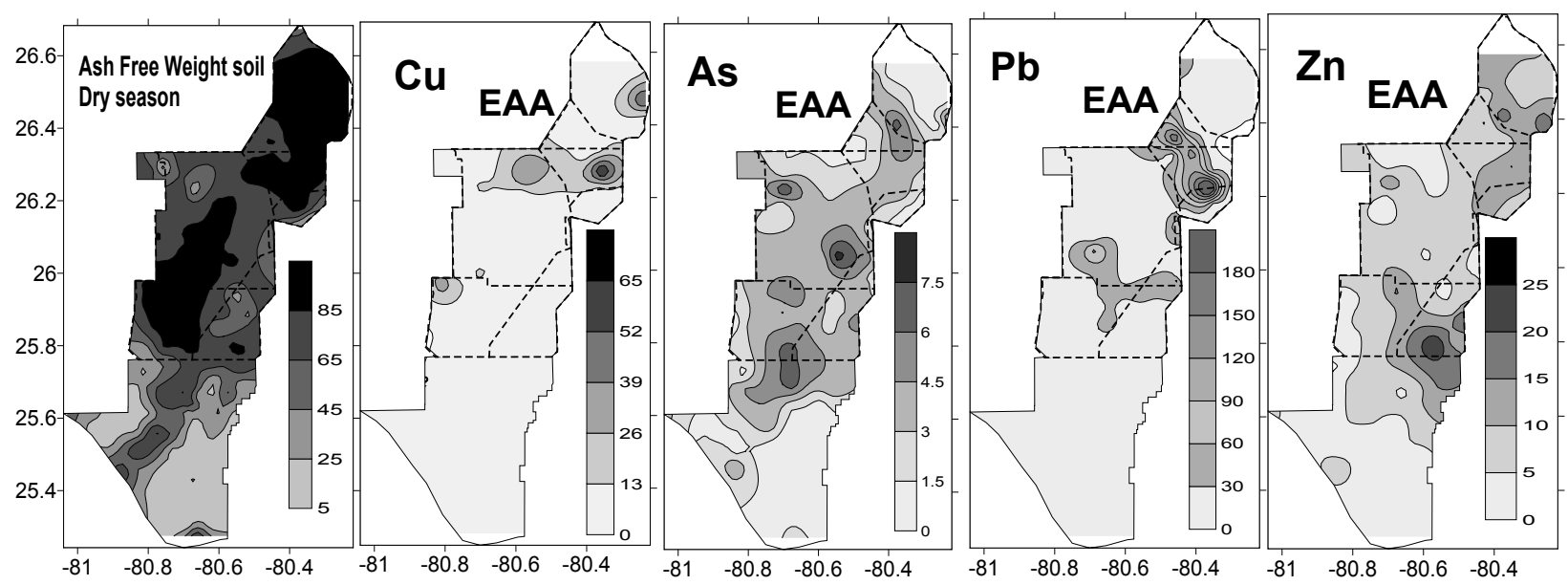

Figure 4-4 Distributions of $\mathrm{Cu}, \mathrm{As}, \mathrm{Pb}$ and $\mathrm{Zn}(\mathrm{mg} / \mathrm{Kg})$ as well as ash free weight (\%) from the dry season. 
Table 4-2 Hard and soft acids (metal ions) and bases (ligands) (EPA 2007).

\begin{tabular}{|c|c|}
\hline Hard acids & $\mathrm{Al}^{2+}, \mathrm{Ba}^{2+}, \mathrm{Be}^{2+}, \mathrm{Co}^{3+}, \mathrm{Cr}^{3+}, \mathrm{Fe}^{3+}, \mathrm{Mn}^{2+}, \mathrm{Sr}^{2+}$ \\
\hline Borderline acids (between hard and soft) & $\mathrm{Cu}^{2+}, \mathrm{Fe}^{2+}, \mathrm{Ni}^{2+}, \mathrm{Pb}^{2+}, \mathrm{Zn}^{2+}$ \\
\hline Soft acids & $\mathrm{Cd}^{2+}, \mathrm{Cu}^{+}, \mathrm{Tl}^{3+}, \mathrm{Tl}^{+}$ \\
\hline Hard bases & $\mathrm{F}^{-}, \mathrm{H}_{2} \mathrm{O}, \mathrm{OH}^{-}, \mathrm{SO}^{2-}, \mathrm{HCO}^{-}$ \\
\hline Borderline bases (between hard and soft) & $\mathrm{Cl}, \mathrm{Br}^{-}, \mathrm{NO}_{2}^{-}, \mathrm{SO}_{3}^{2-}$ \\
\hline Soft bases & $\begin{array}{l}\mathrm{I}, \mathrm{HS}, \mathrm{S}^{2-}, \mathrm{CN}, \mathrm{SCN}, \mathrm{Se}^{2-}, \mathrm{S}_{2} \mathrm{O}_{3}^{2-}, 2-,-\mathrm{SH}, \\
-\mathrm{SCH}_{3},-\mathrm{NH}_{2}, \mathrm{R}-, \mathrm{C}_{2} \mathrm{H}_{4}, \mathrm{C}_{6} \mathrm{H}_{6}, \mathrm{RNC}_{2} \mathrm{CO}, \\
\mathrm{R}_{3} \mathrm{P},(\mathrm{RO})_{3} \mathrm{P}, \mathrm{R}_{3} \mathrm{As}, \mathrm{R}_{2} \mathrm{~S}, \mathrm{RSH}, \mathrm{RS}-\end{array}$ \\
\hline
\end{tabular}

Soil $\mathrm{pH}$ is probably the most important property regulating solubility of metals in soils (Hesterberg 1998). The soil $\mathrm{pH}$ influences virtually the solubility of all metals and their biogeochemical processes in soil, including complexation and acid-base reactions of metal species, dissolution and precipitation of metal solid phases as well as metal sorption. Furthermore, $\mathrm{pH}$ controls binding and speciation of metals by affecting distribution of dissolved ligands (e.g., phosphate, sulfate, carbonate, humic substances) as well as surface charge of binding sites on DOM and solid phases (EPA 2007). In the sediment, sorption to the solid phase controls the concentration of metals in the dissolved phase (common phase of metals exist in oxic sediment pore water). Metal cations (e.g. Mn, Al and Fe) usually increase in solubility (less adsorption) with decreasing in $\mathrm{pH}$ as the surface binding sites are protonated. Conversely, metal cations decrease in solubility (more adsorption) with increasing in $\mathrm{pH}$ (Adriano 1986). The sorption and dissolution patterns are opposite for anionic species such as oxyanions of $\mathrm{As}$, $\mathrm{Mo}$, Se, and $\mathrm{Cr}$, since at high $\mathrm{pH}$ oxyanions competes with $\mathrm{OH}^{-}$ions for sorption sites. In my study, the $\mathrm{pH}$ values in soil were around 5-6 
in LNWR, 7-7.5 in WCA-3, 6.5-7 in WCA-2, and 7-7.5 in ENP (Scheidt and Kalla 2007). Cations, including $\mathrm{Ni}, \mathrm{Mn}, \mathrm{Li}$ and $\mathrm{Be}$ in soil, had elevated concentrations from dry season in ENP where the $\mathrm{pH}$ is the highest (Fig 4-5). The explanation was mentioned earlier. The correlation study showed significant correlations between $\mathrm{pH}$ and most of metals analyzed (Li, Be, Mn, Ni, Cu, As, $\mathrm{Cd}, \mathrm{Zn}, \mathrm{Pb}, \mathrm{Sr}, \mathrm{Al}$ and $\mathrm{K})(\mathrm{p}<0.01)$ in soil (Table 4.3).

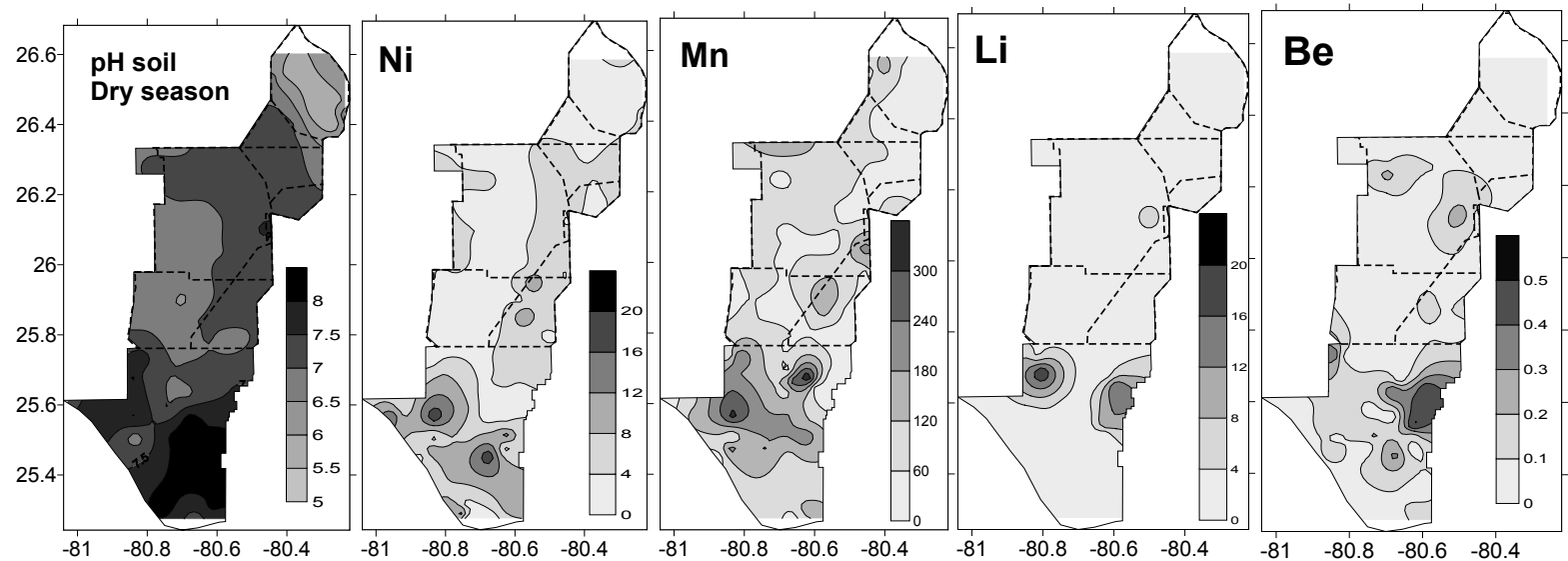

Figure 4-5 Distributions of $\mathrm{Ni}, \mathrm{Mn}, \mathrm{Li}$ and $\mathrm{Be}(\mathrm{mg} / \mathrm{Kg})$ as well $\mathrm{pH}$ from the dry season.

Redox potential affects metal dynamics through metals redox species with more than one possible oxidation state (Warren and Haack 2001). Redox status can impact partitioning of elements between solution and solid phase, resulting in the changes of solubilities of associated toxic metals (Hesterberg 1998). For example, oxyhydroxides solid Fe (III) phase as a result of $\mathrm{Fe}^{3+}$ hydroxylation and precipitation could provide a highly reactive surface for trace metals in aqueous environment. Reduction of Fe and Mn, under reducing conditions, could release associated metals into the water or pore water. Ultimately, those dissolved metals probably would be carried upward by diffusion or downward by precipitation (EPA 2007). In the aquatic environment, oxidation/reduction potential (Eh) measures tendency of 
the solution to gain/lose electrons. High Eh values are maintained in oxidizing or aerobic conditions while low Eh values are maintained in reducing and anaerobic conditions (EPA 2007). Correlations between Eh and most of metals analyzed were not significant except for $\operatorname{Sr}(\mathrm{p}<0.01)$. The weak correlations between metal concentrations in the Everglades and Eh are probably results of stronger influence from other environmental factors (NOM and $\mathrm{pH}$ ). 
Table 4-3 Correlations between metals in matrices (soil and floc) and environmental parameters (DOM, pH, ash free weight (AFW) and Eh)

\begin{tabular}{|c|c|c|c|c|c|c|}
\hline Metals & $\mathrm{pH}$ (r value) & $\mathrm{pH}$ & Eh (r value) & Eh & Ash free weight(r) & Ash free weight \\
\hline $\mathrm{Li}$ & 0.216 & ++ & & & -0.250 & ++ \\
\hline $\mathrm{Be}$ & 0.301 & ++ & & & -0.263 & ++ \\
\hline \multicolumn{7}{|l|}{ V } \\
\hline \multicolumn{7}{|l|}{$\mathrm{Cr}$} \\
\hline $\mathrm{Mn}$ & 0.45 & ++ & & & -0.548 & ++ \\
\hline $\mathrm{Co}$ & & & & & 0.186 & + \\
\hline $\mathrm{Ni}$ & 0.461 & ++ & & & -0.476 & ++ \\
\hline $\mathrm{Cu}$ & -0.184 & + & & & 0.303 & ++ \\
\hline As & -0.197 & ++ & & & 0.489 & ++ \\
\hline $\mathrm{Cd}$ & -0.267 & ++ & & & 0.360 & ++ \\
\hline $\mathrm{Tl}$ & & & & & 0.156 & + \\
\hline $\mathrm{Zn}$ & -0.419 & ++ & & & 0.556 & ++ \\
\hline $\mathrm{Pb}$ & -0.199 & ++ & & & 0.289 & ++ \\
\hline $\mathrm{Sr}$ & 0.458 & ++ & -0.256 & ++ & -0.377 & ++ \\
\hline $\mathrm{Ba}$ & & & -0.169 & + & 0.187 & + \\
\hline $\mathrm{Al}$ & 0.216 & ++ & & & -0.216 & ++ \\
\hline \multicolumn{7}{|l|}{$\mathrm{Fe}$} \\
\hline $\mathrm{K}$ & -0.302 & ++ & & & & \\
\hline $\mathrm{Mg}$ & & & -0.159 & + & & \\
\hline
\end{tabular}


The key parameters affecting metal bioavailability in soils, besides organic matter, soil $\mathrm{pH}, \mathrm{Eh}$, are Fe and Mn oxyhydroxides (EPA 2007). Iron oxyhydroxides include oxides, hydroxides, and oxide hydroxide forms. All forms are very stable and exhibit high energies of crystallization. $\mathrm{Fe}^{3+}$ hydrolyzes and precipitates as oxyhydroxides solid $\mathrm{Fe}$ (III) phase which provides a very reactive surface for trace metals in aqueous environment (Warren and Haack 2001). Like Fe oxides, Mn oxides are very stable state with low solubility. Overall, Mn oxyhydroxides are considered more reactive than Fe oxides. Both $\mathrm{Mn}$ and Fe oxides have high affinities for trace metals, contributing to the variations in concentrations of those metals (Warren and Haack 2001). Both adsorption and co-precipitation (solid solution) might occur between metals and $\mathrm{Fe}$ hydroxides as well as Mn hydroxides under oxidizing conditions; then reduction and dissolution reactions under reducing conditions (EPA 2007). My study showed strong correlations between metals (Ni, As, Cd, Tl, Zn and $\mathrm{Sr}$ ) and $\mathrm{Mn}$ or Fe (Fig 4-4), which may be explained by the strong affinities of Mn or Fe oxides for those metals.

Concentrations of metals in periphyton might be strongly influenced by soil metals uptake by plants (Albers and Camardese 1993). The processes governing availability of trace metals to plants include complexation with organic and inorganic ligands and adsorptions, precipitation and dissolution of solids. Adsorption and precipitation could occur in the uptake of soil metals in roots and shoots (EPA 2007). In strongly acidic soils, plant uptake of $\mathrm{Zn}$, $\mathrm{Mn}$ and Co increase, which might explain the elevated concentrations of those metals in epiphytic periphyton (typically associated with macrophyte) in my study. Manganese, $\mathrm{Zn}$ and Co in epiphytic periphyton all had the highest concentrations in soil with $\mathrm{pH}$ less than 7 (Fig 
4-6). In the benthic periphyton, the distribution of metals might under strong influence of $\mathrm{OM}$ content because of its close association with soils. High concentrations of $\mathrm{Cu}, \mathrm{As}, \mathrm{Pb}$ and $\mathrm{Zn}$ were detected in the soil with highest OM content (Fig 4-7).

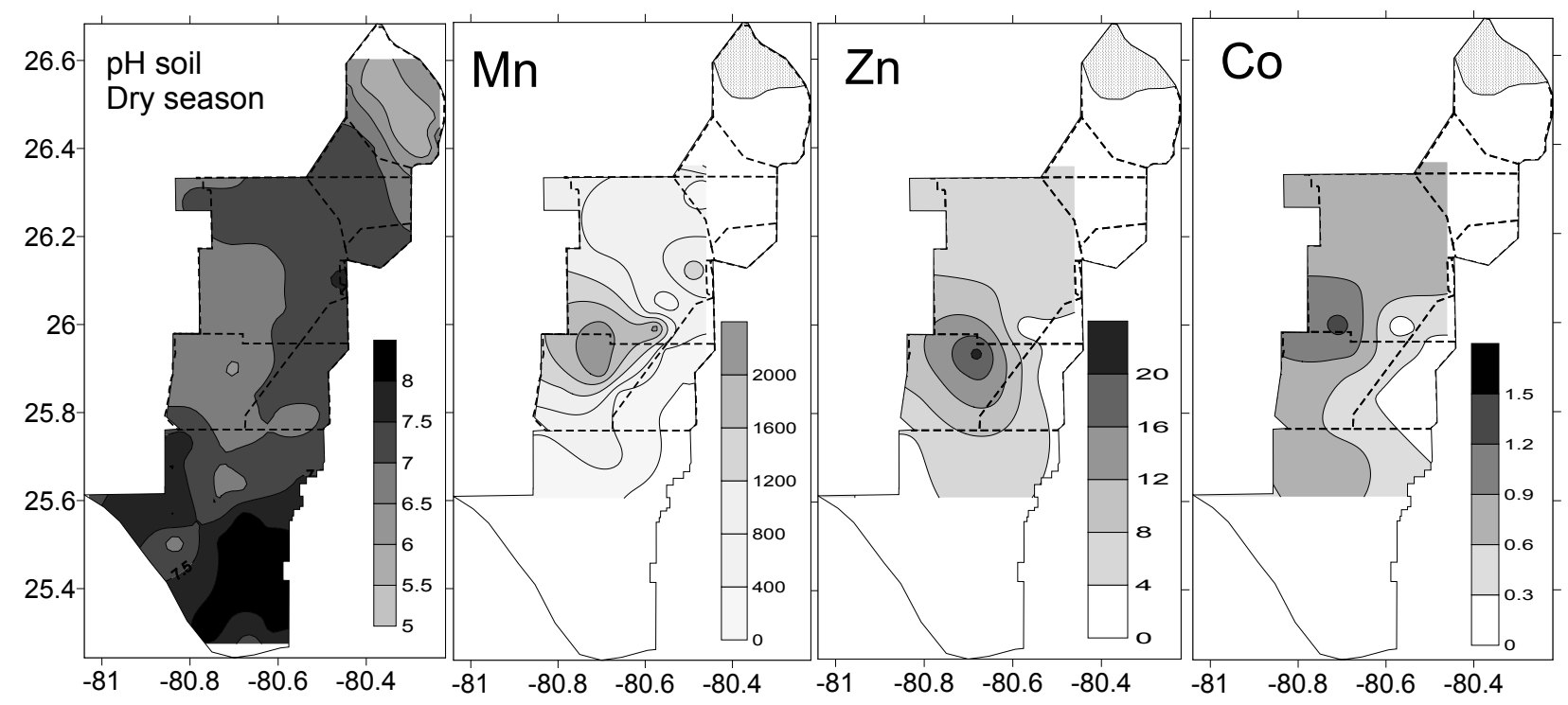

Figure 4-6 Distributions of $\mathrm{Mn}, \mathrm{Zn}$ and $\mathrm{Co}(\mathrm{mg} / \mathrm{Kg})$ in epiphytic periphyton from the dry season 


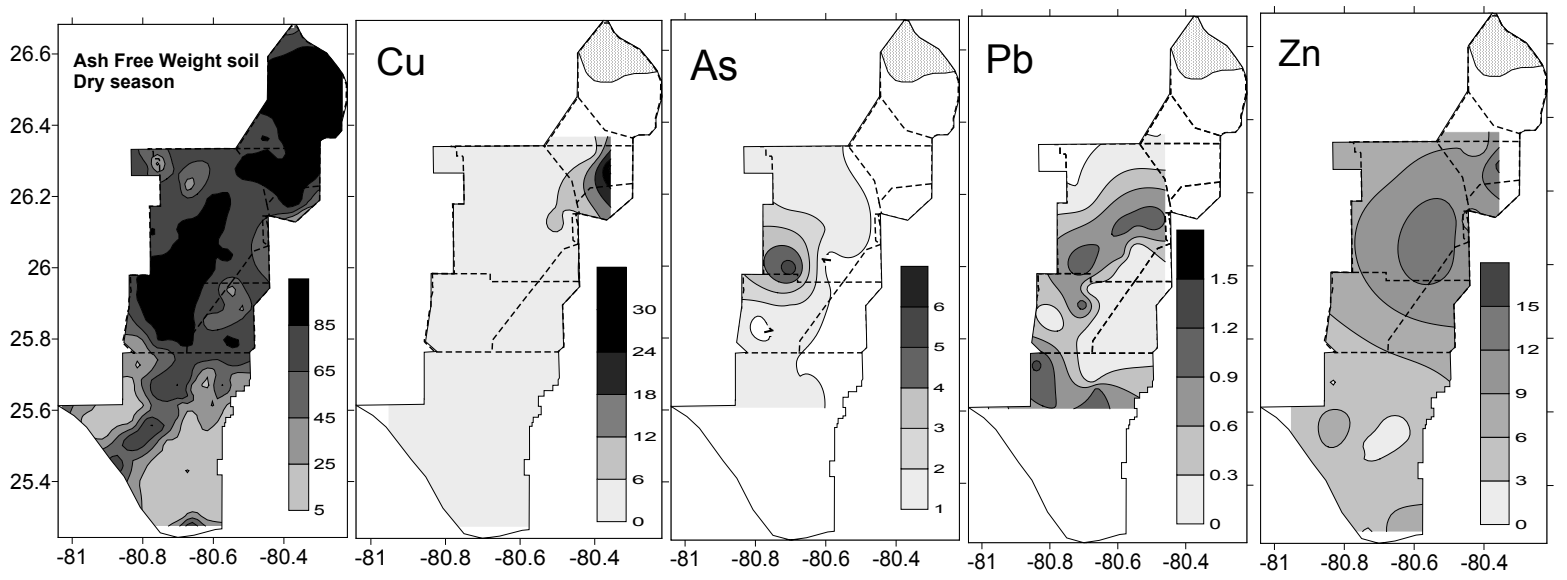

Figure 4-7 Distributions of $\mathrm{Cu}, \mathrm{As}, \mathrm{Pb}$ and $\mathrm{Zn}(\mathrm{mg} / \mathrm{Kg})$ in benthic periphyton from the dry season

In soil (Table 4.4), Zn was significantly correlated with $\mathrm{Mn}, \mathrm{Co}, \mathrm{Cu}, \mathrm{As}, \mathrm{Cd}$ and $\mathrm{Tl}$ $(\mathrm{P}<0.01)$. Pb was correlated with $\mathrm{Mn}, \mathrm{Co}, \mathrm{Cu}, \mathrm{As}, \mathrm{Cd}, \mathrm{Tl}$ and $\mathrm{Zn}(\mathrm{p}<0.05)$. Iron had strong correlation with $\mathrm{Cr}$ and $\mathrm{As}(\mathrm{P}<0.01)$. Copper, $\mathrm{Zn}$, and As are all elements contained in fertilizers, bactericides, and fungicides used in the agriculture. It might explain the close associations among those metals. Underground flow as well as atmospheric deposition from nearby agriculture area might lead to the elevated levels of those metals (Chen et al. 2000). Manganese correlated well with $\mathrm{Ni}, \mathrm{As}, \mathrm{Cd}, \mathrm{Tl}, \mathrm{Zn}$ and Sr. Results imply that potentially toxic metals $\mathrm{Pb}, \mathrm{As}, \mathrm{Ni}, \mathrm{Cd}$ and $\mathrm{Zn}$ maybe closely associated with $\mathrm{Mn}$ - and $\mathrm{Fe}$ - oxides minerals as reported in the literature (Hesterberg 1998). Toxic metals $(\mathrm{Cd}, \mathrm{Pb}, \mathrm{Ni}, \mathrm{As}$ and $\mathrm{Cu})$ correlated among themselves. The possible colloids formed between toxic metals $(\mathrm{Cr}, \mathrm{As}$, $\mathrm{Cd})$ and micronutrients ( $\mathrm{Zn}$ and $\mathrm{Fe}$ ) might explain the indicative correlations between these two groups. In floc (Table 4.5), $\mathrm{Zn}$ was correlated well with $\mathrm{Cu}$, As and $\mathrm{Al}(\mathrm{P}<0.01)$. Iron had strong correlation with As. Manganese in floc only correlated with As $(\mathrm{P}<0.05)$, maybe 
as a result of low concentrations in surface peats in the Everglades (Craft and Richardson 1997). In periphyton (Table 4.6), zinc correlated strongly with $\mathrm{Ni}, \mathrm{Cu}$, As and $\mathrm{Cd}(\mathrm{p}<0.01$ ). $\mathrm{Pb}$ correlated significantly with $\mathrm{As}, \mathrm{Cd}$ and $\mathrm{Zn}$. Iron correlated with $\mathrm{As}, \mathrm{Cd}, \mathrm{Zn}$ and $\mathrm{Al}$. It is probably because of strong affinity of Fe hydroxides for these metals. Living algae and other organism are part of floc and periphyton (Smith 2004). The close correlation among Zn, Fe, $\mathrm{Cu}, \mathrm{Pb}$ might indicate that same origins exist for those metals. 
Table 4-4 Correlation of metals among soil

\begin{tabular}{|c|c|c|c|c|c|c|c|c|c|c|c|c|c|c|c|c|c|c|c|}
\hline & $\mathbf{L i}$ & $\mathbf{B e}$ & $\mathbf{V}$ & $\mathbf{C r}$ & Mn & Co & $\mathrm{Ni}$ & $\mathbf{C u}$ & As & Cd & Tl & $\mathbf{Z n}$ & $\mathbf{P b}$ & $\mathbf{S r}$ & $\mathbf{B a}$ & Al & $\mathbf{F e}$ & $\mathbf{K}$ & $\mathbf{M g}$ \\
\hline $\mathbf{L i}$ & 1 & & & & & & & & & & & & & & & & & & \\
\hline $\mathbf{B e}$ & - & 1 & & & & & & & & & & & & & & & & & \\
\hline V & ++ & - & 1 & & & & & & & & & & & & & & & & \\
\hline $\mathrm{Cr}$ & ++ & + & ++ & 1 & & & & & & & & & & & & & & & \\
\hline Mn & - & - & + & - & 1 & & & & & & & & & & & & & & \\
\hline Co & - & - & - & - & - & 1 & & & & & & & & & & & & & \\
\hline $\mathbf{N i}$ & - & - & - & - & ++ & ++ & 1 & & & & & & & & & & & & \\
\hline $\mathbf{C u}$ & - & - & - & - & + & + & - & 1 & & & & & & & & & & & \\
\hline As & - & - & - & - & ++ & ++ & - & + & 1 & & & & & & & & & & \\
\hline Cd & - & - & - & - & ++ & ++ & ++ & ++ & ++ & 1 & & & & & & & & & \\
\hline $\mathbf{T l}$ & - & - & - & - & ++ & ++ & ++ & ++ & ++ & ++ & 1 & & & & & & & & \\
\hline $\mathbf{Z n}$ & - & - & - & - & ++ & ++ & - & ++ & ++ & ++ & ++ & 1 & & & & & & & \\
\hline $\mathbf{P b}$ & - & - & - & - & + & ++ & - & + & + & + & + & ++ & 1 & & & & & & \\
\hline $\mathrm{Sr}$ & - & - & + & - & ++ & - & ++ & - & - & + & + & + & - & 1 & & & & & \\
\hline $\mathbf{B a}$ & - & + & ++ & - & - & - & - & - & - & - & - & - & - & ++ & 1 & & & & \\
\hline Al & ++ & - & ++ & - & - & - & - & - & - & - & - & ++ & - & - & + & 1 & & & \\
\hline $\mathbf{F e}$ & ++ & - & ++ & + & + & - & - & - & ++ & - & - & - & - & - & - & ++ & 1 & & \\
\hline $\mathbf{K}$ & - & + & ++ & ++ & - & - & ++ & - & - & - & + & - & - & - & + & ++ & - & 1 & \\
\hline Mg & - & - & - & - & - & - & - & - & - & ++ & - & - & - & ++ & ++ & - & - & ++ & 1 \\
\hline
\end{tabular}


Table 4-5 Correlation of metals among floc

\begin{tabular}{|c|c|c|c|c|c|c|c|c|c|c|c|c|c|c|c|c|c|c|c|}
\hline & $\mathbf{L i}$ & $\mathbf{B e}$ & $\mathbf{V}$ & $\mathrm{Cr}$ & Mn & Co & $\mathbf{N i}$ & $\mathbf{C u}$ & As & Cd & Tl & $\mathbf{Z n}$ & $\mathbf{P b}$ & $\mathbf{S r}$ & $\mathbf{B a}$ & Al & $\mathbf{F e}$ & $\mathbf{K}$ & Mg \\
\hline $\mathbf{L i}$ & 1 & & & & & & & & & & & & & & & & & & \\
\hline Be & - & 1 & & & & & & & & & & & & & & & & & \\
\hline V & ++ & - & 1 & & & & & & & & & & & & & & & & \\
\hline $\mathrm{Cr}$ & - & ++ & - & 1 & & & & & & & & & & & & & & & \\
\hline Mn & - & - & - & - & 1 & & & & & & & & & & & & & & \\
\hline Co & - & ++ & - & ++ & - & 1 & & & & & & & & & & & & & \\
\hline $\mathbf{N i}$ & - & - & + & - & - & + & 1 & & & & & & & & & & & & \\
\hline $\mathbf{C u}$ & + & - & + & - & - & - & - & 1 & & & & & & & & & & & \\
\hline As & - & - & - & - & + & ++ & - & - & 1 & & & & & & & & & & \\
\hline Cd & - & - & - & - & - & - & - & - & - & 1 & & & & & & & & & \\
\hline Tl & - & ++ & - & ++ & - & ++ & - & - & - & - & 1 & & & & & & & & \\
\hline $\mathrm{Zn}$ & ++ & - & - & - & - & - & - & ++ & ++ & - & - & 1 & & & & & & & \\
\hline $\mathbf{P b}$ & - & ++ & - & ++ & - & ++ & - & - & - & - & ++ & - & 1 & & & & & & \\
\hline $\mathbf{S r}$ & - & - & - & - & - & - & ++ & - & - & - & - & ++ & - & 1 & & & & & \\
\hline $\mathbf{B a}$ & - & ++ & - & ++ & - & ++ & - & - & - & - & ++ & - & ++ & - & 1 & & & & \\
\hline Al & ++ & - & ++ & - & - & - & - & - & - & - & - & ++ & - & - & - & 1 & & & \\
\hline $\mathbf{F e}$ & - & - & + & - & - & - & - & - & ++ & - & - & - & - & - & - & + & 1 & & \\
\hline $\mathbf{K}$ & - & - & ++ & - & - & - & + & - & - & - & - & - & - & - & - & - & - & 1 & \\
\hline Mg & - & - & + & - & - & - & ++ & - & - & - & - & - & - & ++ & - & - & - & - & 1 \\
\hline
\end{tabular}

Table 4-6 Correlation of metals among periphyton 


\begin{tabular}{|c|c|c|c|c|c|c|c|c|c|c|c|c|c|c|c|c|c|c|c|}
\hline & $\mathbf{L i}$ & $\mathbf{B e}$ & $\mathbf{V}$ & $\mathbf{C r}$ & Mn & Co & $\mathbf{N i}$ & $\mathbf{C u}$ & As & Cd & Tl & $\mathrm{Zn}$ & $\mathbf{P b}$ & $\mathbf{S r}$ & $\mathbf{B a}$ & Al & $\mathbf{F e}$ & $\mathbf{K}$ & Mg \\
\hline $\mathbf{L i}$ & 1 & & & & & & & & & & & & & & & & & & \\
\hline Be & + & 1 & & & & & & & & & & & & & & & & & \\
\hline V & - & - & 1 & & & & & & & & & & & & & & & & \\
\hline $\mathrm{Cr}$ & ++ & - & ++ & 1 & & & & & & & & & & & & & & & \\
\hline Mn & - & - & - & - & 1 & & & & & & & & & & & & & & \\
\hline Co & - & - & - & - & - & 1 & & & & & & & & & & & & & \\
\hline $\mathbf{N i}$ & - & - & + & - & - & ++ & 1 & & & & & & & & & & & & \\
\hline $\mathbf{C u}$ & - & - & - & - & - & - & + & 1 & & & & & & & & & & & \\
\hline As & - & - & + & + & - & + & ++ & ++ & 1 & & & & & & & & & & \\
\hline Cd & - & ++ & ++ & ++ & - & + & ++ & - & ++ & 1 & & & & & & & & & \\
\hline Tl & + & ++ & + & - & - & - & - & - & - & ++ & 1 & & & & & & & & \\
\hline $\mathbf{Z n}$ & - & + & - & ++ & - & - & ++ & ++ & ++ & ++ & + & 1 & & & & & & & \\
\hline $\mathbf{P b}$ & - & - & ++ & - & - & + & - & - & ++ & ++ & - & ++ & 1 & & & & & & \\
\hline $\mathbf{S r}$ & ++ & - & ++ & - & - & - & + & - & - & - & - & - & - & 1 & & & & & \\
\hline $\mathbf{B a}$ & - & + & - & - & ++ & - & - & - & - & - & - & - & - & + & 1 & & & & \\
\hline Al & + & + & - & + & - & - & - & - & - & - & ++ & - & - & - & - & 1 & & & \\
\hline $\mathrm{Fe}$ & - & ++ & + & - & - & + & - & - & ++ & ++ & ++ & ++ & - & - & - & ++ & 1 & & \\
\hline $\mathbf{K}$ & - & - & - & - & - & - & - & - & - & - & - & - & - & - & - & - & - & 1 & \\
\hline $\mathbf{M g}$ & - & - & + & - & - & - & ++ & - & - & - & - & - & - & ++ & - & - & - & - & 1 \\
\hline
\end{tabular}




\subsection{Risk assessment of toxic metals in the Florida Everglades}

Soil is an essential part of ecosystem as it serves as home to most of aquatic plants and animals (Dragovic et al. 2008). Furthermore, toxic metals existing in water at trace level can be accumulated in the sediment. Risk of metals in aquatic systems is commonly evaluated by measuring metal concentrations in soils (Lourino-Cabana et al. 2011). To assess the risk of metals, the background levels of trace metal have to be determined. One of the common ways for conducting risk assessment on metals in sediment is to compare experimental data in sediment with Sediment Quality Guidelines (SQGs). Sediment Quality Guidelines were originally derived using a database generated from studies conducted in both saltwater and freshwater, later better quality data were added to the database (Long et al. 1995). Sediment Quality Guidelines could be divided into two classes, mechanically and empirically based guidelines (Chapman et al. 1998). The mechanical approach accounts for bioavailability through monitoring the chemical and biological processes. Mechanistically based guidelines are derived from theoretical understanding of factors that control the bioavailability of sediment contaminants (Wenning and Ingersoll 2002), which addresses the sources of sediment toxicity, not whether or not the existence of toxic substances in the sediment. Empirical approach utilizes database of sediment chemistry and their biological effects. The most commonly used methods from this approach includes Effects Rangemedian (ERM), Apparent Effects Threshold (AET), Sediment Quality Guideline Quotient 1 (SQGQ1) and Logistic Regression Model (LRM) (Buchman 1999). Out of those methods, SQGQ1 was derived from less number of chemicals than other approaches. Logistic Regression Model approach is difficult to apply because of complex of regression must be utilized to determine probability of toxicity. All guidelines, which can be roughly categorized, 
are used as screening tools for the assessment of potential toxic metals. Table 4.7 listed SQGs used to compare with the current studies, including those derived from U.S., Australia, New Zealand, Italy and Netherland. The category includes: background (BK), which depicts background levels of a constituent in a region or nation; empirically derived (ED), which utilizes sediment chemistry and their biological effects; equilibrium partitioning (EP), which based on aquatic toxicity values; consensus based (CB), which was defined as the average of various SQGs from the same class (Apitz et al. 2007).

When compared average concentrations of potentially toxic metals from the current study (As, $\mathrm{Cd}, \mathrm{Cr}, \mathrm{Ni}, \mathrm{Pb}, \mathrm{Cu}$, and $\mathrm{Zn}$ ) with those of the background-based guidelines, the results from current study are closest to Flemish reference, a background-based guideline (Table 4.7). All results, except for $\mathrm{Pb}$, were below the limit of Flemish reference. The average concentration of toxic metal, $\mathrm{Pb}$, was still less than other background-based guideline. None of toxic metals had mean concentrations exceeded criteria set in the noneffects guidelines as well as probable-effects guidelines. In addition, the results of current study were on par with LEL and TEL values from similar studies conducted in Florida for each compound investigated (Table 4.7). Limited studies have been conducted on the risk assessment of metals in the Everglades. 
Table 4-7 Summary of sediment quality guidelines (SQGs) summary SQG derivation: BK= background based; $\mathrm{ED}=$ empirically derived; $\mathrm{CB}=$ Consensus based. (Apitz et al. 2007)

\begin{tabular}{|c|c|c|c|c|c|c|c|c|}
\hline SQGs & Type & $\begin{array}{l}\text { As } \\
(\mathrm{mg} / \mathrm{Kg})\end{array}$ & $\begin{array}{l}\mathrm{Cd} \\
(\mathrm{mg} / \mathrm{kg})\end{array}$ & $\begin{array}{l}\mathrm{Cr} \\
(\mathrm{mg} / \mathrm{kg})\end{array}$ & $\begin{array}{l}\mathrm{Ni} \\
(\mathrm{mg} / \mathrm{kg})\end{array}$ & $\begin{array}{l}\mathrm{Pb} \\
(\mathrm{mg} / \mathrm{kg})\end{array}$ & $\begin{array}{l}\mathrm{Cu} \\
(\mathrm{mg} / \mathrm{kg})\end{array}$ & $\begin{array}{l}\mathrm{Zn} \\
(\mathrm{mg} / \mathrm{kg})\end{array}$ \\
\hline \multicolumn{9}{|l|}{$\begin{array}{l}\text { Background- } \\
\text { based }\end{array}$} \\
\hline $\begin{array}{l}\text { Flemish ref. } \\
\text { No effects }\end{array}$ & $\mathrm{BK}$ & 11 & 0.4 & 17 & 11 & 14 & 8 & 67 \\
\hline LEL(Florida) & ED & 6 & 0.6 & 26 & 16 & 31 & 16 & 120 \\
\hline TEL(Florida) & ED & 5.9 & 0.6 & 37 & 18 & 35 & 36 & 123 \\
\hline TEL & ED & 7.2 & 0.7 & 52.3 & 15.9 & 30.2 & 18.7 & 124 \\
\hline ERL & ED & 8.2 & 1.2 & 81 & 20.9 & 46.7 & 34 & 150 \\
\hline US TEC & $\mathrm{CB}$ & 7.7 & 0.9 & 66.7 & 18.4 & 38.5 & 26.4 & 137 \\
\hline \multicolumn{9}{|l|}{$\begin{array}{l}\text { Probable } \\
\text { effects }\end{array}$} \\
\hline ERM & ED & 70 & 9.6 & 370 & 52 & 220 & 270 & 410 \\
\hline SEL(Florida) & ED & 33 & 10 & 110 & 75 & 250 & 110 & 820 \\
\hline PEL(Florida) & ED & 17 & 90 & 197 & 36 & 91.3 & 197 & 315 \\
\hline PEL & ED & 41.6 & 4.2 & 160.4 & 42.8 & 112.2 & 108.2 & 271 \\
\hline AET & ED & 35 & 3 & 62 & 110 & 400 & 390 & 410 \\
\hline $\operatorname{PEC}(\mathrm{I})$ & $\mathrm{CB}$ & 54.3 & 5.8 & 268.5 & 58.3 & 296 & 214.6 & 396.2 \\
\hline US PEC & $\mathrm{CB}$ & 56.2 & 5.5 & 208.8 & 68.1 & 253.4 & 256.1 & 363.7 \\
\hline
\end{tabular}

Table 4-8 Percentages of toxic metals over the SQG's limit from sediment and floc samples

\begin{tabular}{llllllll}
\hline Soil (N=195) & As & Cd & Cr & Ni & Pb & Cu & Zn \\
\hline LEL(FL) & $8.2(16)$ & $0.5(1)$ & $10.1(20)$ & $1.5(3)$ & $16.9(33)$ & $3.6(7)$ & None \\
US TEC & $2.1(4)$ & none & none & & $6.7(13)$ & $1.5(3)$ & None \\
TEC (I) & None & None & none & & $5.1(10)$ & $1.5(3)$ & None \\
SEL(FL) & None & none & none & & $0.5(1)$ & & None \\
floc (N=151) & & & & & & & \\
LEL(FL) & $15.2(23)$ & $0.7(1)$ & None & $5.3(8)$ & None & $11.3(17)$ & None \\
US TEC & $2.6(4)$ & none & none & $2.6(4)$ & none & $9.3(14)$ & None \\
TEC (I) & None & None & none & $1.3(2)$ & none & $3.3(5)$ & None \\
SEL(FL) & None & none & none & none & none & $0.7(1)$ & None \\
\hline
\end{tabular}

Although the mean values of the toxic metals did not exceed the no-effects SQGs, multiple samples had concentrations of toxic metals over several SQGs (LEL (FL), US TEC, TEC (I) and SEL (FL)) in the no-effect category (Table 4.8). Given relatively high 
background concentrations of As in the Everglades soils compared to rest of the state of Florida with $7.02 \mathrm{mg} / \mathrm{Kg}$ being the highest concentration in the state (Chen et al. 2001), both wet and dry seasons' As concentrations in soils didn't exceed the background value. Other toxic metals $(\mathrm{Cd}, \mathrm{Cr}, \mathrm{Ni}$ and $\mathrm{Pb})$ have no known background concentrations information. Both LEL and SEL are guidelines made specifically based on sediment samples from state of Florida. Both TECs were average values of guidelines made in domestic and international respectively. Lead and $\mathrm{Cr}$ from sediments, as well as $\mathrm{As}$ and $\mathrm{Cu}$ from Floc, had concentrations over LEL level set in Florida in more than $10 \%$ of total sample. However, only one sample from each compartment contained concentrations of toxic metals $(\mathrm{Pb}$ and $\mathrm{Cu}$ ) over criteria of probable-effects SQGs. The use of various SQGs, derived both domestically and internationally, has been utilized to evaluate the possibility of toxicity levels of COPECs in the Everglades. Even though most surveyed area contained samples with concentrations well under the limit set by SQGs from the probable-effects class, some areas, such as LNWR, northwestern part of WCA-3 in the surrounding area of EAA) should be subjected to site-specific risk assessment for carrying high concentration of toxic metals at several sites. Arsenic, $\mathrm{Cr}$, and $\mathrm{Pb}$ from sediment contained concentration levels that pose dangers to ecological and human receptors as multiple samples exceeded background SQGs (Table 17) in the northern region in ENP and part of LNWR and Water Conservation Area-2. For floc, samples were found in the northern area of WCA-3 with elevated concentrations in As, $\mathrm{Ni}$ and $\mathrm{Cu}$ (Figure 4-8). The elevated level of those toxic metals (As, $\mathrm{Pb}$ and $\mathrm{Ni}$ ) might affect aquatic plants and animals in the vicinity of contaminated area, causing biological harms such as metabolite degradation, enzyme activity inhibition, calcium metabolism problem, among others. 


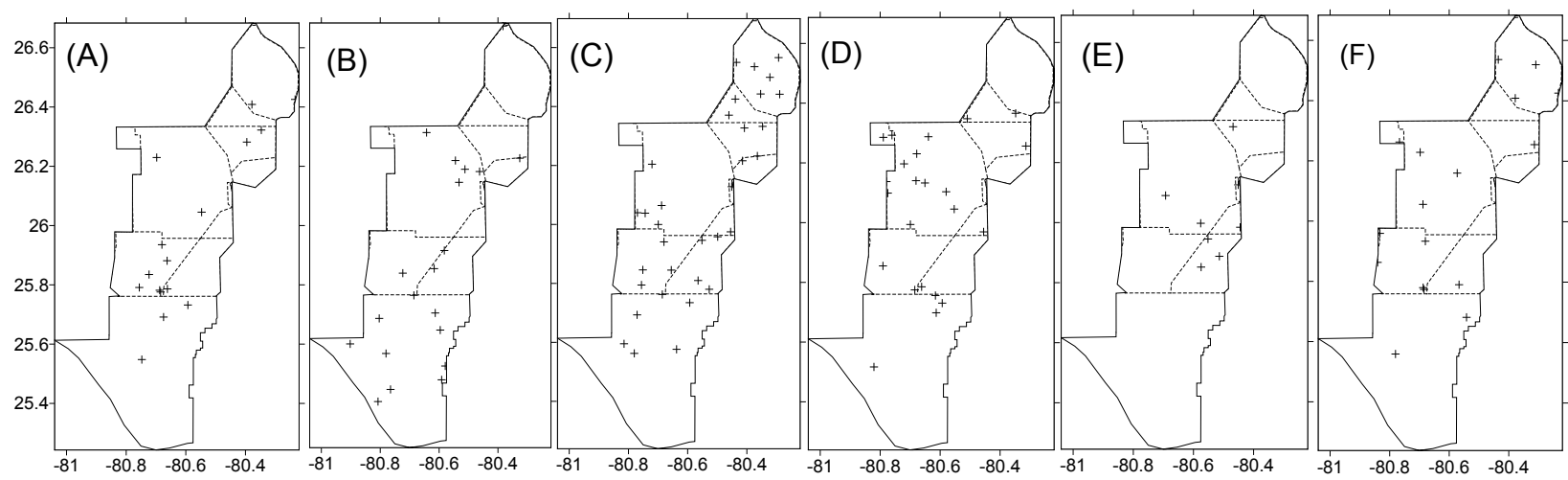

Figure 4-8 Spatial distribution of selected toxic metals with concentrations exceeding SQGs in soils (A) As, (B) Cr, (C) Pb, and in floc of Florida Everglades (D) As, and (E) Ni, (F) Cu

\section{Conclusions}

The highest mean concentrations of all metals analyzed in the Everglades were detected in soil, followed by floc and periphyton. Most of metals in soil exhibited maximum concentrations in the dry season. The nearly opposite occurred for floc, where only $\mathrm{Cr}, \mathrm{Ni}$, and $\mathrm{Cu}$ were more concentrated in the dry season. Seasonal variation had little influence on the concentration in metals from periphyton. Most metals exhibited random spatial distribution patterns.

The distribution and concentration of dissolved metals in soils are possibly under the influence of major anthropogenic sources: agriculture and development activities $(\mathrm{Cu}, \mathrm{Pb}, \mathrm{Zn}$, and As), road dusts and associated pollutions ( $\mathrm{Cr}$ and $\mathrm{Zn}$ ), air-boat tours (As and $\mathrm{Zn}$ ) and air trafficking $(\mathrm{Cr}$ and $\mathrm{Zn})$. The environmental parameters, including $\mathrm{NOM}$ and $\mathrm{pH}$, are essential in the control over the distribution of metals in the Everglades as well. The highest concentrations of $\mathrm{Cu}, \mathrm{As}, \mathrm{Pb}$ and $\mathrm{Zn}$ were found in the peat soil where $\mathrm{OM}$ content is high. 
Cations ( $\mathrm{Ni}, \mathrm{Mn}, \mathrm{Li}$ and $\mathrm{Be}$ ) had elevated concentrations in the south of the Everglades where $\mathrm{pH}$ is the highest.

Risk assessment using SQGs concluded that all toxic metals $(\mathrm{Cd}, \mathrm{Cr}, \mathrm{Pb}, \mathrm{Ni}, \mathrm{Cu}, \mathrm{Zn}$ and As) exhibited average concentrations that were well below FL guidelines as well as other domestic and international guidelines. Although none of concentrations of toxic metals exceeded SQGs levels defined by "probable effects", several metals (As, $\mathrm{Cr}, \mathrm{Pb}, \mathrm{Ni}$ and $\mathrm{Cu}$ ) had elevated concentrations at several sampling sites in northern ENP, WCA-2 and LNWR. Overall, based on the current study, the Everglades can be considered a pristine environment. This study can serve as a baseline for future analysis of metals in the Everglades area.

\section{Future work}

Some areas, such as northwestern and northeastern zone of ENP, contained elevated concentrations of toxic metals $(\mathrm{Cr}$, As and $\mathrm{Ni}$ ) which warrant further investigation into their sources and impacts. High concentrations of toxic metals $(\mathrm{Cd}, \mathrm{Cr}$ and $\mathrm{Pb})$ in the surrounding areas of EAA encourage the additional study of the influence on the toxic metals from the agricultural and developmental activities. A screening level Ecological Risk Assessment (ERA) with metals is recommended to quantify the likelihood that detrimental effects will incur in the sediment from metal exposures. The study of toxic metal pollutions in the Everglades fish and plants should be conducted as to assess the potential risk associated with metals. Future sediment-toxicity studies should also be carried out to distinguish between natural and anthropogenic effects on distributions of metals. 


\section{Reference}

Adriano, D. C. (1986). Trace Elemtns in the Terrestrial Environment. New York, Springer-Verlag.

Agrawal, H., Sawant, A. A., Jansen, K., Miller, J. W., et al. (2008). "Characterization of chemical and particulate emissions from aircraft engines." Atmospheric Environment 42(18): 4380-4392.

Aiken, G. R., Gilmour, C. C., Krabbenhoft, D. P. and Orem, W. (2011). "Dissolved Organic Matter in the Florida Everglades: Implications for Ecosystem Restoration." Critical Reviews in Environmental Science and Technology 41: 217-248.

Aiken, G. R., Hsu-Kim, H. and Ryan, J. N. (2011). "Influence of Dissolved Organic Matter on the Environmental Fate of Metals, Nanoparticles, and Colloids." Environmental Science \& Technology 45(8): 3196-3201.

Albers, P. H. and Camardese, M. B. (1993). "Effects of acidification on metal accumulation by aquatic plants and invertebrates .2. wetlands, ponds and small lakes." Environmental Toxicology and Chemistry 12(6): 969-976.

Apeagyei, E., Bank, M. S. and Spengler, J. D. (2011). "Distribution of heavy metals in road dust along an urban-rural gradient in Massachusetts." Atmospheric Environment 45(13): 2310-2323.

Apitz, S. E., Barbanti, A., Bernstein, A. G., Bocci, M., et al. (2007). "The assessment of sediment screening risk in Venice lagoon and other coastal areas using international sediment quality guidelines." Journal of Soils and Sediments 7(5): 326-341.

Aposhian, H. V. and Aposhian, M. M. (2006). "Arsenic toxicology: Five questions." Chemical Research in Toxicology 19(1): 1-15.

Birch, G. F., Vanderhayden, M. and Olmos, M. (2011). "The Nature and Distribution of Metals in Soils of the Sydney Estuary Catchment, Australia." Water Air and Soil Pollution 216(1-4): 581-604.

Brown, G. E., Foster, A. L. and Ostergren, J. D. (1999). "Mineral surfaces and bioavailability of heavy metals: A molecular-scale perspective." Proceedings of the National Academy of Sciences of the United States of America 96(7): 3388-3395.

Buchman, M. F. (1999). "NOAA Screening Quick Reference Tables. Seattle WA,: Coastal Protection and Restorartion Division, National Ocenaic and Atmosphyeric Administration." NOAA HAZMAT Report 99-1.

Burger, J. (2008). "Assessment and management of risk to wildlife from cadmium." Science of the Total Environment 389(1): 37-45.

Caccia, V. G. and Millero, F. J. (2003). "The distribution and seasonal variation of dissolved trace metals in Florida Bay and adjacent waters." Aquatic Geochemistry 9(2): 111-144.

Caccia, V. G., Millero, F. J. and Palanques, A. (2003). "The distribution of trace metals in Florida Bay sediments." Marine Pollution Bulletin 46(11): 1420-1433. 
Cai, Y., Jaffe, R. and Jones, R. D. (1999). "Interactions between dissolved organic carbon and mercury species in surface waters of the Florida Everglades." Applied Geochemistry 14(3): 395-407.

Calace, N., Caliandro, L., Petronio, B. M., Pietrantonio, M., et al. (2012). "Distribution of Pb, Cu, Ni and $\mathrm{Zn}$ in urban soils in Rome city (Italy): effect of vehicles." Environmental Chemistry 9(1): 69-76.

Carnahan, E. A., Hoare, A. A., Hallock, P., Lidz, B. H., et al. (2008). "Distribution of heavy metals and foraminiferal assemblages in sediments of Biscayne Bay, Florida, USA." Journal of Coastal Research 24(1): 159-169.

Carriger, J. F., Rand, G. M., Gardinali, P. R., Perry, W. B., et al. (2006). "Pesticides of potential ecological concern in sediment from south Florida canals: An ecological risk prioritization for aquatic arthropods." Soil \& Sediment Contamination 15(1): 21-45.

Chaney, R. L. and Ryan, J. A. (1993). Heavy metals and toxic organic pollutants in MSW-composts: Research results on phytoavailability, bioavailability, fate, etc., Keener (ed) Science and Engineering of Composting: Design, Environmental.

Chapman, P. M., Wang, F. Y., Janssen, C., Persoone, G., et al. (1998). "Ecotoxicology of metals in aquatic sediments: binding and release, bioavailability, risk assessment, and remediation." Canadian Journal of Fisheries and Aquatic Sciences 55(10): 2221-2243.

Chen, M., Ma, L. Q., Hoogeweg, C. G. and Harris, W. G. (2001). "Arsenic background concentrations in Florida, USA surface soils: Determination and interpretation." Environmental Forensics 2(2): 117-126.

Chen, M., Ma, L. Q. and Li, Y. C. (2000). "Concentrations of P, K, Al, Fe, Mn, Cu, Zn, and As in marl soils from south Florida." Soil and Crop Science Society of Florida Proceedings 59: 124-129.

Chen, T. B., Wong, J. W. C., Zhou, H. Y. and Wong, M. H. (1997). "Assessment of trace metal distribution and contamination in surface soils of Hong Kong." Environmental Pollution 96(1): 61-68.

Christensen, T. H., Kjeldsen, P., Bjerg, P. L., Jensen, D. L., et al. (2001). "Biogeochemistry of landfill leachate plumes." Applied Geochemistry 16(7-8): 659-718.

Clarke, A. L. and Dalrymple, G. H. (2003). "\$7.8 billion for Everglades Restoration: Why do environmentalists look so worried?" Population and Environment 24(6): 541-569.

Clijsters, H. and Vanassche, F. (1985). "Inhibition of photosynthesis by heavy-metals." Photosynthesis Research 7(1): 31-40.

Cohen, M. J., Lamsal, S., Osborne, T. Z., Bonzongo, J. C. J., et al. (2009). "Soil Total Mercury Concentrations across the Greater Everglades." Soil Science Society of America Journal 73(2): 675685.

Craft, C. B. and Richardson, C. J. (1997). "Relationships between soil nutrients and plant species composition in everglades peatlands." Journal of Environmental Quality 26(1): 224-232. 
Dammgen, U., Luttich, M. and Scholz-Seidel, C. (2000). "Atmospheric deposition of cadmium to agricultural areas in Germany." Landbauforschung Volkenrode 50(3-4): 103-131.

Davis, J. A. and Leckie, J. O. (1978). "Effect of adsorbed complexing ligands on trace-metal uptake by hydrous oxides." Environmental Science \& Technology 12(12): 1309-1315.

Davis, S. M. (1991). "Growth, decomposition, and nutrient retention of cladium-jamaicense crantz and typha-domingensis pers in the florida everglades." Aquatic Botany 40(3): 203-224.

deMiguel, E., Llamas, J. F., Chacon, E., Berg, T., et al. (1997). "Origin and patterns of distribution of trace elements in street dust: Unleaded petrol and urban lead." Atmospheric Environment 31(17): 2733-2740.

Demirdjian, B., Ferry, D., Suzanne, J., Popovicheva, O. B., et al. (2007). "Heterogeneities in the microstructure and composition of aircraft engine combustor soot: Impact on the water uptake." Journal of Atmospheric Chemistry 56(1): 83-103.

Dragovic, S., Mihailovic, N. and Gajic, B. (2008). "Heavy metals in soils: Distribution, relationship with soil characteristics and radionuclides and multivariate assessment of contamination sources." Chemosphere 72(3): 491-495.

Droppo, I. G. (2001). "Rethinking what constitutes suspended sediment." Hydrological Processes 15(9): 1551-1564.

Duester, L., Diaz-Bone, R. A., Kosters, J. and Hirner, A. V. (2005). "Methylated arsenic, antimony and tin species in soils." Journal of Environmental Monitoring 7(12): 1186-1193.

Elnabarawy, M. T., Welter, A. N. and Robideau, R. R. (1986). "Relative sensitivity of 3 daphnid species to selected organic and inorganic chemicals." Environmental Toxicology and Chemistry 5(4): 393-398.

EPA, U. S. (2007). Framework for Metals Risk Assessment

Office of the Science Advisor. Risk Assessment Forum. Washington, DC, U.S. Environmental Protection Agency. EPA 120/R-07/001.

EPA, U. S. (2010). Advance Notice of Proposed Rulemaking on Lead Emissions from Piston-Engine Aircraft Using Leaded Aviation Gasoline.

Evans, D. W. and Crumley, P. H. (2005). "Mercury in Florida Bay fish: Spatial distribution of elevated concentrations and possible linkages to Everglades restoration." Bulletin of Marine Science 77(3): 321-345.

Förstner, U. and Wittmann, G. T. W. (1981). Metal Pollutions in the Aquatic Enivronement. New York, Springer Verlag.

Florea, A. M. and Busselberg, D. (2006). "Occurrence, use and potential toxic effects of metals and metal compounds." Biometals 19(4): 419-427. 
Frimmel, F. H. (1998). "Characterization of natural organic matter as major constituents in aquatic systems." Journal of Contaminant Hydrology 35(1-3): 201-216.

FWC. (2012). "Florida airboat regulations." from http://myfwc.com/.

Gaiser, E. E., Childers, D. L., Jones, R. D., Richards, J. H., et al. (2006). "Periphyton responses to eutrophication in the Florida Everglades: Cross-system patterns of structural and compositional change." Limnology and Oceanography 51(1): 617-630.

Garcia, R., Maiz, I. and Millan, E. (1996). "Heavy metal contamination analysis of roadsoils and grasses from Gipuzkoa (Spain)." Environmental Technology 17(7): 763-770.

Gough, L. P., Kotra, R. K., Holmes, C. W., Orem, W. H., et al. (2000). Regional Geochemistry of Metals in Organic-Rich Sediments, Sawgrass and Surface Water, from Taylor Slough, Florida. OFR00-327. U. S. G. Survey.

Goyer, R. A. (1997). "Toxic and essential metal interactions." Annual Review of Nutrition 17: 37-50.

Hajje, N. and Jaffe, R. (2006). "Molecular characterization of Cladium peat from the Florida Everglades: biomarker associations with humic fractions." Hydrobiologia 569: 99-112.

Hesterberg, D. (1998). "Biogeochemical cycles and processes leading to changes in mobility of chemicals in soils." Agriculture Ecosystems \& Environment 67(2-3): 121-133.

Horrocks, M. and Ogden, J. (1994). "Modern pollen spectra and vegetation of Mt Hauhungatahi, central north-island, New-Zealand." Journal of Biogeography 21(6): 637-649.

Huang, F. N. and Schneider, J. S. (2004). "Effects of lead exposure on proliferation and differentation of neural stem cells derived from different regions of embryonic rats brain." Neurotoxicology 25(6): 1001-1012.

Jahnke, L. S. and Soulen, T. K. (1978). "Effects of manganese on growth and restoration of photosynthesis in manganese deficient algae." Zeitschrift Fur Pflanzenphysiologie 88(1): 83-93.

Johnston, J. E. (1984). Impacts of Airboats on Loxahatchee National Wildlife Refuge Part 2 - longterm impacts of airboat use under the hunt restrictions. Interim report to the Fish and Wildlife service Vero Beach, Florida, Fish and Wildlife service.

Kabata-Pendias, A. (2004). "Soil-plant transfer of trace elements - an environmental issue." Geoderma 122(2-4): 143-149.

Kaznina, N. M., Laidinen, G. F., Titov, A. F. and Talanov, A. V. (2005). "Effect of lead on the photosynthetic apparatus of annual grasses." Biology Bulletin 32(2): 147-150.

KcKee, K. L. (1993). "Soil physicochemical patterns and mangrove species distribution: reciprocal effects?" Journal of Ecology 81: 477-487.

Knauer, K., Jabusch, T. and Sigg, L. (1999). "Manganese uptake and Mn(II) oxidation by the alga Scenedesmus subspicatus." Aquatic Sciences 61(1): 44-58. 
KTMB. (2012). "kendall-Tamiami Executive Airport (KTMB) general facts." from http://www.miami-airport.com/kendall_facts.asp.

Kushlan, J. A. and Hunt, B. P. (1979). Florida Scientist 42: 65-84.

Ledin, M. (2000). "Accumulation of metals by microorganisms - processes and importance for soil systems." Earth-Science Reviews 51(1-4): 1-31.

Lee, C. W., Choi, J. M. and Pak, C. H. (1996). "Micronutrient toxicity in seed geranium (Pelargonium $\mathrm{x}$ hortorum Bailey)." Journal of the American Society for Horticultural Science 121(1): 77-82.

Lee, D. S., Pitari, G., Grewe, V., Gierens, K., et al. (2010). "Transport impacts on atmosphere and climate: Aviation." Atmospheric Environment 44(37): 4678-4734.

Lee, S. Z., Chang, L., Yang, H. H., Chen, C. M., et al. (1998). "Adsorption characteristics of lead onto soils." Journal of Hazardous Materials 63(1): 37-49.

Light, A. R. (2010). "Reducing Nutrient Pollution in the Everglades Agricultural Area through best management practices." Natural Resources \& the Environment 25: 26.

Light, S. S. and Dineer, J. W. (1994). Water control in the Everglades: a historical perspective. Delray Beach, Florida, USA, St. Lucie Press.

Liu, G. L., Cai, Y., Mao, Y. X., Scheidt, D., et al. (2009). "Spatial Variability in Mercury Cycling and Relevant Biogeochemical Controls in the Florida Everglades." Environmental Science \& Technology 43(12): 4361-4366.

Liu, G. L., Cai, Y., Philippi, T., Kalla, P., et al. (2008). "Distribution of total and methylmercury in different ecosystem compartments in the Everglades: Implications for mercury bioaccumulation." Environmental Pollution 153(2): 257-265.

Liu, G. L., Naja, G. M., Kalla, P., Scheidt, D., et al. (2011). "Legacy and Fate of Mercury and Methylmercury in the Florida Everglades." Environmental Science \& Technology 45(2): 496-501.

Logan, E. M., Pulford, I. D., Cook, G. T. and MacKenzie, A. B. (1997). "Complexation of Cu2+ and $\mathrm{Pb} 2+$ by peat and humic acid." European Journal of Soil Science 48(4): 685-696.

Long, E. R., MacDonald, D. D., Smith, S. L. and Calder, F. D. (1995). "Incidence of adverse bilogical effects within ranges of chemical concentrations in marine and estuarine sediments." Environmental Management 19(1): 81-97.

Lourino-Cabana, B., Lesven, L., Charriau, A., Billon, G., et al. (2011). "Potential risks of metal toxicity in contaminated sediments of Deule river in Northern France." Journal of Hazardous Materials 186(2-3): 2129-2137.

Lu, R., Turco, R. P., Stolzenbach, K., Friedlander, S. K., et al. (2003). "Dry deposition of airborne trace metals on the Los Angeles Basin and adjacent coastal waters." Journal of Geophysical ResearchAtmospheres 108(D2). 
Marchetti, C. (2003). "Molecular targets of lead in brain neurotoxicity." Neurotoxicity Research 5(3): 221-235.

Mass, M. J., Tennant, A., Roop, B. C., Cullen, W. R., et al. (2001). "Methylated trivalent arsenic species are genotoxic." Chemical Research in Toxicology 14(4): 355-361.

McCormick, P. V., Rawlik, P. S., Lurding, K., Smith, E. P., et al. (1996). "Periphyton-water quality relationships along a nutrient gradient in the northern Florida Everglades." Journal of the North American Benthological Society 15(4): 433-449.

McPherson, B. F. (1990). Water-Quality Assessment of Southern Florida-Wastewater Discharges and Runoff, U.S. Geological Survey.

Mejia, C. A. Z., Gonzalez, J. T. and Monzon, I. T. (2011). "Heavy metal concentration and distribution $(\mathrm{Pb}, \mathrm{Zn}, \mathrm{Cu}, \mathrm{Cd}$ and $\mathrm{Cr})$ in urban road sediments." Revista Facultad De IngenieriaUniversidad De Antioquia(58): 53-62.

MePherson, B. F. and Halley, R. (1996). The South Florida Environment-A Region Under Stress, U.S. Geological Survey Circular 1134.

Merkel, R. S. and Hickey-Vargas, R. (2000). "Element and sediment accumulation rates in the Florida Everglades." Water Air and Soil Pollution 122(3-4): 327-349.

Mikalajune, A. and Jakucionyte, L. (2011). "Investigation into heavy metal concentration by the gravel roadsides." Journal of Environmental Engineering and Landscape Management 19(1): 89-100.

Nagajyoti, P. C., Lee, K. D. and Sreekanth, T. V. M. (2010). "Heavy metals, occurrence and toxicity for plants: a review." Environmental Chemistry Letters 8(3): 199-216.

Neto, R. R., Mead, R. N., Louda, J. W. and Jaffe, R. (2006). "Organic biogeochemistry of detrital flocculent material (floc) in a subtropical, coastal wetland." Biogeochemistry 77(3): 283-304.

Nriagu, J. O. (1988). "A Silent Epidemic of Environmental Metal Poisoning." Environmental Pollution 50(1-2): 139-161.

Othman, I., AlOudat, M. and AlMasri, M. S. (1997). "Lead levels in roadside soils and vegetation of Damascus city." Science of the Total Environment 207(1): 43-48.

Pagotto, C., Remy, N., Legret, M. and Le Cloirec, P. (2001). "Heavy metal pollution of road dust and roadside soil near a major rural highway." Environmental Technology 22(3): 307-319.

Peraza, M. A., Ayala-Fierro, F., Barber, D. S., Casarez, E., et al. (1998). "Effects of micronutrients on metal toxicity." Environmental Health Perspectives 106: 203-216.

Perkins, S. M., Filippelli, G. M. and Souch, C. J. (2000). "Airborne trace metal contamination of wetland sediments at Indiana Dunes National Lakeshore." Water Air and Soil Pollution 122(1-2): 231-260. 
Perry, K. D., Cahill, T. A., Eldred, R. A., Dutcher, D. D., et al. (1997). "Long-range transport of North African dust to the eastern United States." Journal of Geophysical Research-Atmospheres 102(D10): 11225-11238.

Perry, W. B. (2008). "Everglades restoration and water quality challenges in south Florida." Ecotoxicology 17(7): 569-578.

Piotrowska, A., Bajguz, A., Godlewska-Zylkiewicz, B. and Zambrzycka, E. (2010). "Changes in Growth, Biochemical Components, and Antioxidant Activity in Aquatic Plant Wolffia arrhiza (Lemnaceae) Exposed to Cadmium and Lead." Archives of Environmental Contamination and Toxicology 58(3): 594-604.

Pironfrenet, M., Bureau, F. and Pineau, A. (1994). "Lead accumulation in surface roadside soil - its relationship to traffic density and meteorological parameters." Science of the Total Environment 144: 297-304.

Rand, G. M. and Schuler, L. J. (2009). "Aquatic Risk Assessment of Metals in Sediment from South Florida Canals." Soil \& Sediment Contamination 18(2): 155-172.

Raposo, A. B., da Cruz, A. J. A., Adriano, C. M. and Magalhaes, L. P. (2001). "Coordination components for collaborative virtual environments." Computers \& Graphics-Uk 25(6): 1025-1039.

Rehage, J. S. and Trexler, J. C. (2006). "Assessing the net effect of anthropogenic disturbance on aquatic communities in wetlands: community structure relative to distance from canals." Hydrobiologia 569: 359-373.

Rendell, H. M., Webster, S. E. and Sheffer, N. L. (1994). "Underwater bleaching of signals from sediment grains - new experimental-data." Quaternary Science Reviews 13(5-7): 433-435.

Richards, B. K., Schulte, B. M., Heilig, A., Steenhuis, T. S., et al. (2004). "Environmental impacts of applying manure, fertilizer, and sewage biosolids on a dairy farm." Journal of the American Water Resources Association 40(4): 1025-1042.

Rossi, S. C. and Wetterhahn, K. E. (1989). "Chromium(v) is produced upon reduction of chromate by mitochondrial electron-transport chain complexes." Carcinogenesis 10(5): 913-920.

Salem, H., Seabaugh, V. and Katz, A. (1994). "Proceedings symposium on ocular effects of organophosphate exposure - june 4, 1992 - preface." Journal of Applied Toxicology 14(2): 104-104.

Sauve, S., Hendershot, W. and Allen, H. E. (2000). "Solid-solution partitioning of metals in contaminated soils: Dependence on $\mathrm{pH}$, total metal burden, and organic matter." Environmental Science \& Technology 34(7): 1125-1131.

Schauer, J. J., Lough, G. C., Shafer, M. M., Christensen, W. F., et al. (2006). "Characterization of metals emitted from motor vehicles." Health Effect Institute 133: 1-88.

Scheidegger, C., Behra, R. and Sigg, L. (2011). "Phytochelatin formation kinetics and toxic effects in the freshwater alga Chlamydomonas reinhardtii upon short- and long-term exposure to lead(II)." Aquatic Toxicology 101(2): 423-429. 
Scheidt, D. J. and Kalla, P. (2007). Everglades ecosystem assessment: water management and quality, eutrophication, mercury contamination, soils and habitat: monitoring for adaptive management: a REMAP status report. USEPA Region 4, Athens, GA. EPA 904-R-07-001: 98 pp.

Schell, J. D. and Rechsteiner, M. (2000). "Replacement of chromium electroplating using advanced material technologies on gas turbine engine components." Plating and Surface Finishing 87(7): 17-23.

Schulze, D. G. (1989). An introduction to soil mineralogy.

SFWMD, U. a. (1999). Central and Southern Florida Project Comprehensive Review Study, Final Integrated Feasibility Report and Programmatic Environmental Impact Statement. Jacksonville District, Jacksonville, FL, USA and South Florida Water Management District, West Palm Beach, FL, USA.

Sharma, V. K. and Sohn, M. (2009). "Aquatic arsenic: Toxicity, speciation, transformations, and remediation." Environment International 35(4): 743-759.

Sillman, S., Marsik, F. J., Al-Wali, K. I., Keeler, G. J., et al. (2007). "Reactive mercury in the troposphere: Model formation and results for Florida, the northeastern United States, and the Atlantic Ocean." Journal of Geophysical Research-Atmospheres 112(D23).

Sklar, F., McVoy, C. and Van Zee, R. (1999). Hydrologic Needs: The Effects of Altered Hydrology on the Everglades. Everglades Interim Report.

Smith, S. E. (2004). Defining the role of floating periphyton mats in shaping food-web dynamics in the Florida Everglades. Miami,FL, Florida International University. PhD dissertation.

Strom, R. N., Braman, R. S., Jaap, W. C., Dolan, P., et al. (1992). "Analysis of selected trace metals and pesticides offshore of the Florida Keys " Florida Scientist 55(1): 1-13.

Su, Y. Y., He, Y., Lu, H. T., Sai, L. M., et al. (2009). "The cytotoxicity of cadmium based, aqueous phase - Synthesized, quantum dots and its modulation by surface coating." Biomaterials 30(1): 19-25.

Sullivan, K. A. and Aller, R. C. (1996). "Diagenetic cycling of arsenic in Amazon shelf sediments." Geochimica Et Cosmochimica Acta 60(9): 1465-1477.

Thornberry, T. E. (2008). Everglades National Park Geologic Resource Evaluation Report, National Park Service.

Tolley, M. R., Smyth, P. and Macaskie, L. E. (1992). "Metal toxicity effects the biological treatment of aqueous metal wastes - is a biocatalytic system feasible for the treatment of wastes containing actinides." Journal of Environmental Science and Health Part a-Environmental Science and Engineering \& Toxic and Hazardous Substance Control A27(2): 515-532.

Turer, D., Maynard, J. B. and Sansalone, J. J. (2001). "Heavy metal contamination in soils of urban highways: Comparison between runoff and soil concentrations at Cincinnati, Ohio." Water Air and Soil Pollution 132(3-4): 293-314. 
Upadhyay, R. and Panda, S. K. (2010). "Zinc reduces copper toxicity induced oxidative stress by promoting antioxidant defense in freshly grown aquatic duckweed Spirodela polyrhiza L." Journal of Hazardous Materials 175(1-3): 1081-1084.

Verkleji, J. A. C. (1993). The effects of heavy metal stress on higher plants and their use as biomonitors. New York.

Viard, W., Pihan, F., Promeyrat, S. and Pihan, J. C. (2004). "Integrated assessment of heavy metal $(\mathrm{Pb}, \mathrm{Zn}, \mathrm{Cd})$ highway pollution: bioaccumulation in soil, Graminaceae and land snails." Chemosphere 55(10): 1349-1359.

Viarengo, A. and Nott, J. A. (1993). "Mechanisms of heavy-metal cation homeostasis in marineinvertebrates." Comparative Biochemistry and Physiology C-Pharmacology Toxicology \& Endocrinology 104(3): 355-372.

Warren, L. A. and Haack, E. A. (2001). "Biogeochemical controls on metal behaviour in freshwater environments." Earth-Science Reviews 54(4): 261-320.

Weeks (1989). Turbidity Investigation on Halfway Creek-Big Cypress National Preserve, National Park Service.

Weng, L. P., Temminghoff, E. J. M., Lofts, S., Tipping, E., et al. (2002). "Complexation with dissolved organic matter and solubility control of heavy metals in a sandy soil." Environmental Science \& Technology 36(22): 4804-4810.

Wenning, R. J. and Ingersoll, C. G. (2002). Use of Sediment Quality Guidelines and Related Tools for the Assessment of Contaminated Sediments. Executive Summary of a SETAC Pellston Workshop, ENVIRON International Corporation.

Windom, H. L., Schropp, S. J., Calder, F. D., Ryan, J. D., et al. (1989). "Natural trace-metal concentrations in estuarine and coastal marine-sediments of the southeastern united-states." Environmental Science \& Technology 23(3): 314-320.

Wright, A. (2000). "Not Just a Bunch of Hot Air -- The Ecological Impacts of Airboats." Road RIPorter 6(1).

Wright, A. L. and Reddy, K. R. (2001). "Heterotrophic microbial activity in northern Everglades wetland soils." Soil Science Society of America Journal 65(6): 1856-1864.

Yamataki, H. (1994). "Agency Position Statement: Condition of Soils in ORV Use Areas at Big Cypress National Preserve." Letter to P. Kenney, Big Cypress National Preserve. Fort Myers, FL, USDA Soil Conservation Service.

Zafra, C. A., Temprano, J. and Tejero, I. (2011). "Distribution of the concentration of heavy metals associated with the sediment particles accumulated on road surfaces." Environmental Technology 32(9): 997-1008. 